\title{
OS AMBIENTES CONTRATUAL E OPERACIONAL DA CÉDULA DE PRODUTO RURAL (CPR) E INTERAÇÕES COM OS MERCADOS FUTUROS E DE OPÇÕES
}

\author{
BERNARDO CELSO DE REZENDE GONZALEZ \\ Licenciado em Matemática
}

Orientador: Prof. Dr. Pedro Valentim Marques

Tese apresentada à Escola Superior de Agricultura "Luiz de Queiroz", Universidade de São Paulo, para obtenção do título de Doutor em Ciências, Área de Concentração: Economia Aplicada.

PIRACICABA

Estado de São Paulo - Brasil

Janeiro - 1999 
Dados Internacionais de Catalogação na Publicação (CIP) DIVISÃo DE BIBLIOTECA E DOCUMENTAÇÃO - Campus "Luiz de Queiroz"/USP

\section{Gonzales, Bernardo Celso de Rezende}

Os ambientes contratual e operacional da cédula de produto rural (CPR) e interaçoes com os mercados futuros e de opçōes / Bernardo Celso de Rezende Gonzales. - - Piracicaba, 1999.

$169 \mathrm{p}$.

Tese (doutorado) - - Escola Superior de Agricultura Luiz de Queiroz, 1999. Bibliografia.

1. Café 2. Cédula de produto rural 3. Economia agrícola 4. Financiamento agrícola 5. Mercado de futuro 6. Mercado a termo I. Título 
A Vera, companheira de todos os momentos, e a nossos filhos Mariana e Rodolfo.

Meus três grandes amores! 


\section{AGRADECIMENTOS}

Quando concluí minha dissertação de mestrado deparei-me com a página destinada aos agradecimentos. Não foi difícil preenchê-la.

Neste momento, contudo, sinto grande dificuldade em expressar o devido reconhecimento a todos que direta ou indiretamente contribuíram para o coroamento do objetivo a que me propus, tantos eles são. Assim, reservo-me o direito de não mencionar nomes, para, embora lugar-comum, não magoar pessoas de quem sou tributário e que eventualmente seriam esquecidas por traição da memória.

Principio pelos colegas de curso. É inegável o bem que me fizeram pelas discussões, pelos estudos em grupo e pela solidariedade que prestaram e, já que falo de colegas, aos companheiros do Banco do Brasil que me deixaram à vontade na cidade $e$ me auxiliaram em muitas de minhas necessidades.

Aos funcionários da ESALQ que, indistintamente, sempre foram prestativos e atenciosos; a meu orientador e aos demais membros da banca de seminário e de qualificação, por aceitarem participar e pelas contribuições que fizeram; aos professores da Departamento de Economia da ESALQ, com quem tive o privilégio de conviver e aprender; a um grande número de gerentes e funcionários de agências do Banco do Brasil, pelo auxílio dado à efetivação das entrevistas; aos funcionários da GECOM/BBCPR pela disponibilização de dados e apoio logístico; à CETIP e à BM\&F pelo formecimento de dados e, ao Banco do Brasil e ao $\mathrm{CNPq}$, por me propiciarem os recursos financeiros necessários à dedicação exclusiva ao Doutorado.

Como todas nossas conquistas são de natureza coletiva, embora o trabalho final apareça como de caráter individual, agradeço sinceramente a todos que contribuíram para mais esta etapa de minha vida. 


\section{SUMÁRIO}

Página

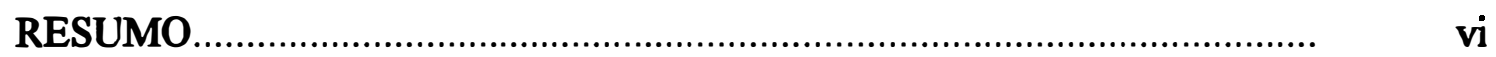

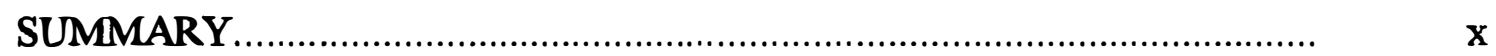

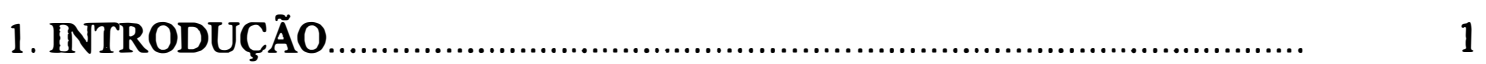

1.1 Visão geral do problema.......................................................................

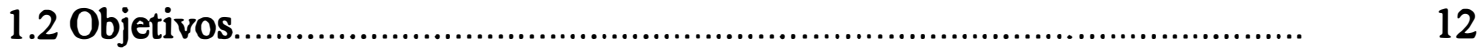

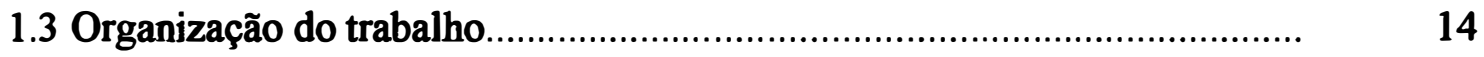

2. O MERCADO A TERMO E A CÉDULA DE PRODUTO RURAL ........... 16

2.1 Agropecuária e risco econômico............................................................... 16

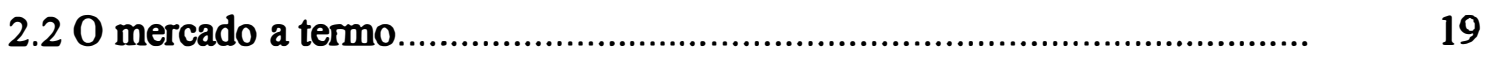

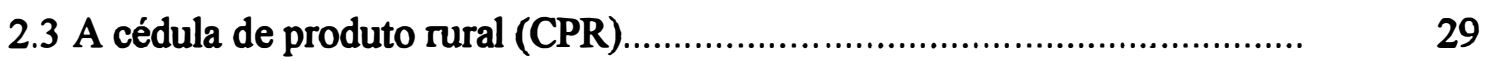

2.3.1 Origens e características........................................................................ 29

2.3.2 Utilização pelo mercado......................................................................

2.3.3 O desenho dos contratos................................................................. 37

2.3.4 0 processo de formação de preços....................................................... $\quad 40$

2.3.5 A utilização de estratégias combinadas................................................. 43

2.3.6 A CPR com liquidação financeira........................................................ 49

2.4 Considerações finais sobre o capítulo...................................................... 53

3. O MERCADO DE DERIVATIVOS .................................................. 54

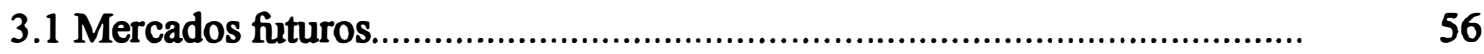

3.1.1 Participação no mercado................................................................... $\quad 60$

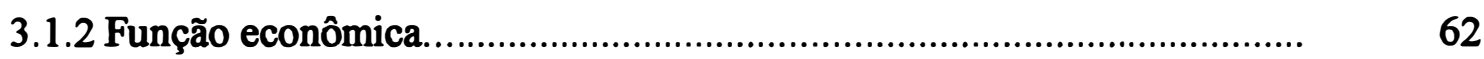

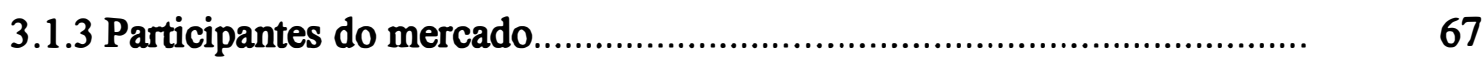

3.1.4 Variações de preço/base................................................................... 71

3.1.5 Razão ótima de hedging/eficiência......................................................... 75

3.1.6 A substitutibilidade entre os comratos futuros e a termo......................... 77 


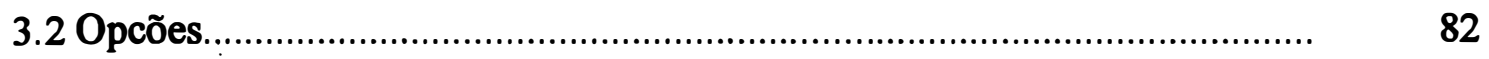

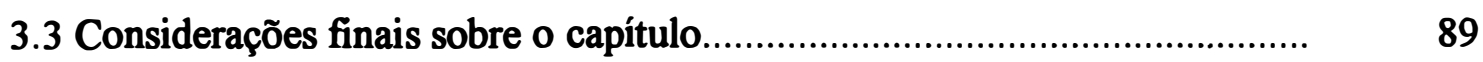

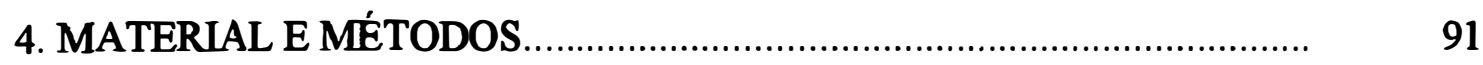

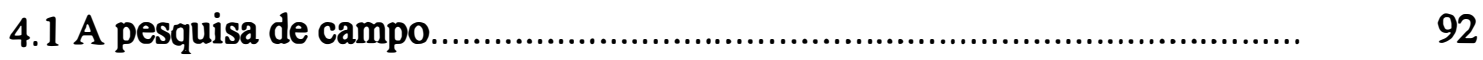

4.2 Os papéis de financiamento e hedging.................................................. 95

4.2.1 A CPR como instrumento de financiamento......................................... 95

4.2.2 A CPR como instrumento de hedging................................................... 98

4.2.3 A utilização de op̧̧ões na apropriação do diferencial positivos de

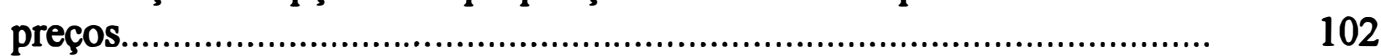

4.3 Considerações finais sobre o capítulo........................................................ 104

5. DISCUSSÃO E ANÁLISE DOS RESULTADOS DA PESQUISA DE CAMPO.

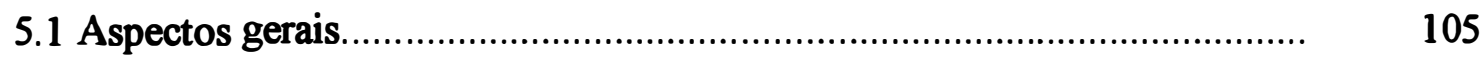

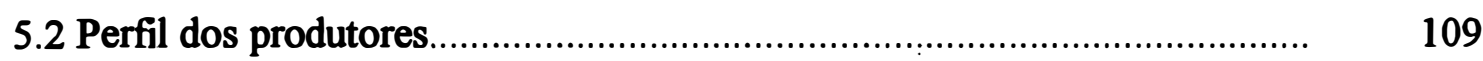

5.3 Aspectos relativos à operação de venda da CPR ......................................... 113

5.4 Avaliação financeira do negócio............................................................. 117

5.5 A opinião livre dos produtores................................................................ 122

5.6 Considerações finais sobre o capítulo..................................................... 126

6. CPR: financiamento e hedging ................................................................. 128

6.1 A CPR como instrumento de financiamento........................................... 128

6.2 A CPR como instrumento de hedging ................................................ 134

6.3 A utilização de opções na apropriação dos diferenciais de elevação de

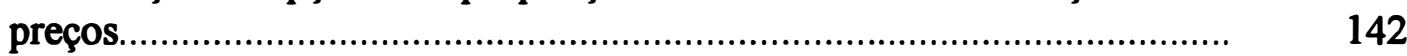

6.4 Considerações finais sobre o capítulo......................................................... 145

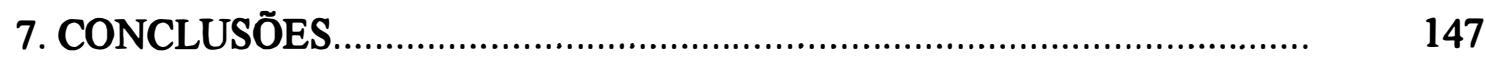

REFERÊNCIAS BIBLIOGRÁFICAS................................................. 156

APÊNDICE "A" - formulário para entrevistas........................................... 163

APÊNDICE "B” - CETIP, informações semanais).................................... 166 


\title{
OS AMBIENTES CONTRATUAL E OPERACIONAL DA CÉDULA DE PRODUTO RURAL (CPR) E INTERAÇÕES COM OS MERCADOS FUTUROS E DE OPÇÕES
}

\author{
Autor: Bernardo Celso de Rezende Gonzalez \\ Orientador: Prof. Dr. Pedro Valentim Marques
}

\section{RESUMO}

O cenário prevalecente na agricultura brasileira na década de 70 era de crédito abundante e subsidiado. Na década de 80 , com a crise fiscal, essa realidade se alterou substancialmente. $\mathrm{O}$ crédito tornou-se escasso e com taxas positivas de juros, forçando os agentes do agribusiness a buscar alternativas que propiciassem o financiamento privado das safras.

É assim que surge, em 1994, a Cédula de Produto Rural (CPR), cambial que permite aos produtores rurais vender a termo sua produção, recebendo de imediato o respectivo valor e se comprometendo a entregar o produto na quantidade, qualidade e no local e data estipulados no título

Embora surgida como alternativa de financiamento, a CPR transcende esse papel: serve como instrumento de hedging; permite a fixação de uma dada rentabilidade ao fixar receitas e custos; permite o escoamento da produção e, sobretudo, propicia que as operações de plantio e tratos culturais sejam feitas de forma adequada, assegurando (abstraídas as condições bioclimáticas) um volume normal de produção. 
Dada a incipiência da CPR, este trabalho teve o caráter de servir como estudo exploratório. Buscou, no campo teórico, caracterizar seus ambientes contratual e operacional, situando-a no contexto dos contratos a termo, evidenciando algumas de suas interações com os derivativos agropecuários.

Adicionalmente, através de amostragem aleatória estratificada, pesquisou-se a opinião dos cafeicultores que realizaram vendas através de CPR nas safras 96/97 e 97/98. Os principais resultados mostraram: baixa utilização dos instrumentos derivativos; que a falta de recursos foi a principal causa de procura pelo título; que, num cenário de crédito rural abundante, os produtores continuariam a utilizar a CPR; que a maioria teve o sentimento de que ganharam dinheiro, sendo que a quase totalidade dos produtores sentiu-se entre satisfeitos e muito satisfeitos com a transação.

Buscou-se, ainda, a avaliação da CPR enquanto instrumento de financiamento e hedging. No primeiro caso, comparou-se o custo financeiro para o produtor com as taxas CDI-over e de capital de giro. Como a taxa over é uma taxa de captação, considera-se um bom resultado quando o custo dos recursos dela se aproxima. No entanto, das 38 observações, apenas 5 (13,2\%) situaram-se nesse patamar. Nas demais, 24 (63,2\%) situaram-se em níveis inferiores à taxa de capital de giro (cerca de $28 \%$ abaixo), enquanto o restante a ultrapassou.

Com relação ao hedging, um ajuste teve que ser feito: atualizou-se o preço da CPR para o seu vencimento, com $90 \%$ da taxa over numa primeira alternativa, e com a taxa de remuneração da poupança, em outra. Realizado esse ajuste, percebeu-se que no primeiro caso o hedging por CPR, comparado com os contratos futuros, teria sido favorável em 68,4\% das oportunidades, enquanto, para o segundo, esse percentual atingiu apenas $36,8 \%$. Em outras palavras, admitindo-se a taxa de poupança na atualização do preço, a vantagem se transfere para os contratos futuros. 
Por último, considerou-se a possibilidade de o produtor, vendido em CPR, poder se apropriar de eventuais aumentos de preços, pela aquisição de op̧̧ões de compra. Se considerado o preço da CPR ajustado por $90 \%$ da taxa CDI-over, das 38 observações, a possibilidade de renda adicional ocorreu em 20 oportunidades (52,6\%), sendo que em 4 dessas oportunidades o ganho teria sido residual, enquanto nas demais houve possibilidade de ganhos expressivos. 


\title{
THE CONTRACTUAL AND OPERATIONAL ENVIRONMENT OF BILL OF RURAL PRODUCT (CPR) AND INTERACTIONS WITH FUTURES AND OPTIONS MARKETS
}

\author{
Author: Bemardo Celso de Rezende Gonzalez \\ Adviser: Professor Pedro Valentim Marques
}

\section{SUMMARY}

The reality of Brazilian Agriculture in the decade of 70 was that of plentiful and subsidized credit. In the eighties, with the fiscal crisis, that scenery changed dramatically. The credit became scarce and with positive rates of interests, compelling the agribusiness agents to search for alternatives that could propitiate the private financing of the crops. In this context was created, in 1994, the Bill of Rural Product (CPR), that is a bond that allows the farmer forward sells his production but making cash immediately. The producer commits himself to deliver the product in the amount, quality and in place and date specified in the contract.

The CPR appeared as a financing alternative but, being a forward contract, it plays other roles like: price protection against falls; flowing the production off and, above all, it propitiates that the cultural plantation/cultivation be made in an appropriate way, assuring (abstracting the bioclimatic conditions) a normal volume of production.

Being the CPR a incipient bond, this thesis had an exploratory meaning. It was searched, in the theoretical field, to delineate its contractual and operational 
environment, locating it in the context of the cash forward contracts and pointing out some interactions with the agricultural derivatives.

Additionally, through random sampling it was researched the opinion of coffee farmers that had made sales in the 1996/97 and 1997/98 crop years. The maim results showed: the little utilization of derivatives instruments; that the lack of financial resources was the main reason which they searched for the bond; that the farmers would continue to write CPR's even though the rural credit scenery was a plentiful one; that the majority had the feeling that they made money.

Another objective was to evaluate the CPR as a financing and hedging instrument. In the first case, the farmers' financing interest rate was compared with the rates of CDI (inter-banks loan rates) and of working capital. The CDI is also a referential rate for money reception, becoming interesting to get money at the same level However, from 38 observations, just 5 (13.2\%) were located in that level. From the total, 24 (63.2\%) were located in inferior levels to the working capital rate (about $28 \%$ below), while the remaining surpassed it.

For the verification of CPR as a hedging instrument, its price needed to be adjusted for the contract maturity. It was used in the comparisons two accrued rates: the remuneration of Brazilian savings account (RSA) and the CDI. For the first case, the hedging through CPR overcame the hedging through futures contracts in $68.4 \%$ of the opportunities, while for the second situation the results were inverted. The futures contracts overcame CPR in $63.2 \%$ of the cases.

Finally, it was considered the possibility that a farmer, short in CPR, could take advantage of raising prices motions through long positions in calls. Considering the CPR's price adjusted by $90 \%$ of CDI, it is possible to verify that from 38 observations, the possibility of additional income occurred in 20 opportunities (52.6\%). From this 20 opportunities, in four the profit was residual, while the others showed good results. 


\section{INTRODUÇÃO}

\subsection{Visão geral do problema}

O modelo econômico brasileiro esteve assentado, desde o início da colonização, basicamente sobre a exploração agropecuária. Quando o processo de modemização urbano-industrial do País foi iniciado, a atividade rural detinha hegemonia na economia brasileira.

Coube ao campo, então, o papel de gerador dos recursos excedentes necessários à industrialização. $\mathrm{O}$ setor rural, nessa época, forneceu fluxo migratório capaz de garantir a necessária mão-de-obra para a indústria nascente, a um salário compatível com a capacidade de remuneração de então. Além disso, transferiu, voluntária ou compulsoriamente, parte dos recursos que financiaram os investimentos nas cidades. Produziu matéria-prima e os alimentos para os trabalhadores recém convertidos em operários, sempre a preços compatíveis com as necessidades de acumulação das atividades em implantação.

Com a transformação da realidade econômica do País, o setor rural foi se enfraquecendo em termos relativos e absolutos. Teve sua participação na renda interna reduzida em 15 pontos percentuais entre 1949 e 1970 (Castro e Alimandro, 1990). Em decorrência, a capacidade de transferir recursos foi sendo comprometida, razão pela qual criaram-se alguns mecanismos que viriam a compensar, pelo menos parcialmente, as perdas que se vinham processando. Dentre tais mecanismos destaca-se o Sistema 
Nacional de Crédito Rural-SNCR, o qual incorporou uma política de subsídios para o setor.

A grande predominância do crédito subsidiado ocorreu na década de 70 . Seus objetivos eram, basicamente, o de expandir a fronteira agrícola e propiciar a modemização tecnológica da atividade. Essa foi uma década cujo enfoque no setor rural foi bastante expressivo e o reflexo de tal política foi um grande aumento na área plantada, além de expressivos ganhos de produtividade (ver Figura 1).

No entanto, ao lado dos beneficios introduzidos, os subsídios causaram deformações alocativas, propiciando concentração de renda, uma vez que o acesso ao crédito era mais fácil aos produtores melhor informados/capacitados a dele fazer uso (normalmente os grandes), deixando à margem grande contingente de produtores (Sayad, 1984).

Com a crise fiscal dos anos 80 , além de os custos de financiamento terem sido alterados, com a introdução de taxas superiores à correção monetária, os recursos colocados à disposição do setor, para o financiamento de suas atividades, foram reduzidos drasticamente. Registrem-se os anos iniciais do Governo Collor, onde a tônica foi deixar a agropecuária ao sabor do livre jogo das forças de mercado.

Em síntese, a economia brasileira viveu ao longo de sua história períodos contínuos de crescimento de seu Produto Interno Bruto, culminando com taxas expressivas na década de 70 , em função das quais, cunhou-se para aquele período a expressão "Milagre Brasileiro". No entanto, o crescimento econômico não se sustentou. $\mathrm{Na}$ década seguinte, ponderados os anos de recuos e de crescimento do PIB, o produto permaneceu relativamente estabilizado (obviamente com queda no produto per capita), fazendo com que esse período ficasse conhecido na sociedade como a "década perdida". 
O cenário econômico da década de oitenta, que afetou todos os setores da economia, trouxe à agropecuária fortes mudanças, as quais impuseram uma adaptação forçada ao setor. $\mathrm{O}$ crédito, antes farto e subsidiado, tornou-se escasso e com taxas positivas de juros. Como a agricultura, mais que a pecuária, estava amplamente ancorada em financiamentos, o choque foi bastante sentido.

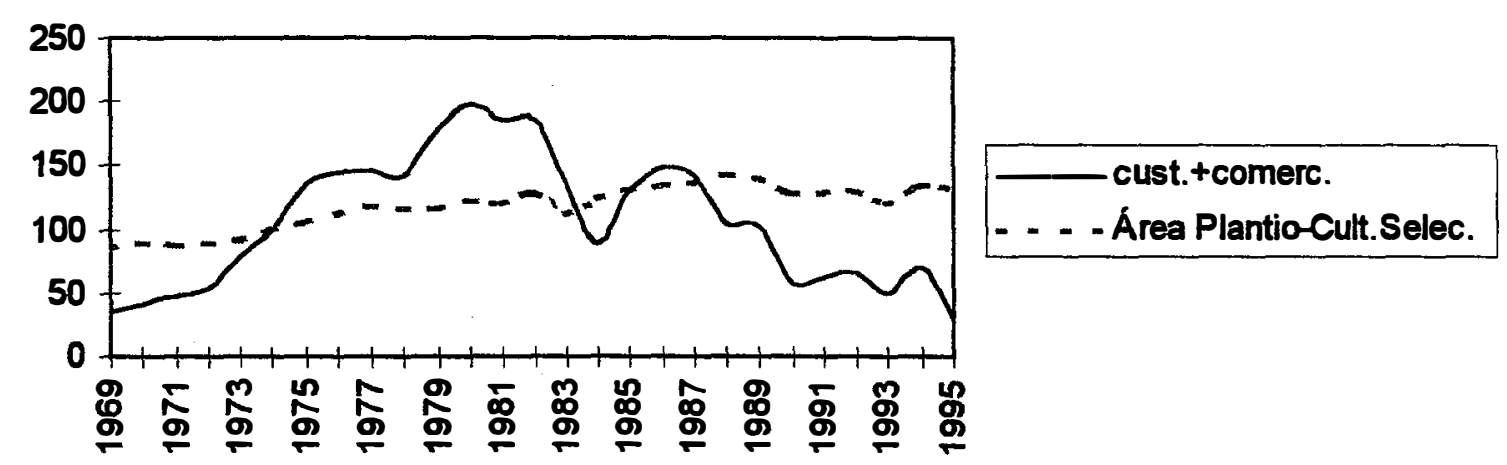

Figura 1 - Brasil - crédito rural de custeio e comercialização e área plantada de culturas selecionadas $-1969 / 1995(1974=100)$

A Figura 1, obtida a partir de dados da ANFAVEA (1996) e de Anuários Estatísticos do IBGE, mostra, de forma bastante eloqüente, como foi a distribuição de crédito de custeio e de comercialização durante o período de 1969 a 1995. Os volumes de crédito alocados tiveram uma trajetória crescente desde 1969, atingindo o ápice em 1980. A partir desse ano a necessidade de adequação da política econômica ao segundo choque do petróleo (ocorrido em 1979) e aos aumentos sem precedentes das taxas de juros internacionais afetaram o volume de crédito alocado, fazendo com que se iniciasse um movimento de declínio.

O declínio ocorreu até o ano de 1984, reagindo, em 1985, devido à necessidade de alocação de recursos adicionais visando ao replantio de lavouras fortemente atingidas 
por estiagem na região Centro-Sul e, como corolário, serviu para dar sustentação política ao Presidente José Samey, que iniciava seu governo após o trauma vivenciado pelo País com a morte do Presidente eleito Tancredo Neves (Gonzalez e Costa, 1998, p.15). Em 1986 o volume de crédito voltou a subir. No entanto, dessa vez foram a euforia e a extraordinária monetização da economia provocadas pelo Plano Cruzado que alicerçaram esse movimento.

No mesmo gráfico é evidenciada a trajetória de comportamento da área plantada com as culturas de arroz, milho, trigo, feijão, soja, mandioca, algodão, cana-de-açúcar e laranja. Essas lavouras foram escolhidas por se inserirem nos pólos mais dinâmicos da agricultura brasileira e por terem sido as principais beneficiárias da política de crédito rural. Goldin e Rezende (1993, p.24) afirmam que $80 \%$ de todo o crédito rural concedido entre 1970 e 1991 foi destinado às culturas de soja, trigo, arroz, milho, café e cana-deaçúcar. Nos dados que deram suporte ao gráfico não foi considerada a cultura de café, devido à reordenação produtiva pela qual passou a partir da segunda metade da década de 70 .

Visualmente, a área plantada respondeu aos movimentos ocorridos com a alocação de crédito de custeio e comercialização até o ano de 1983. Em seguida à queda apresentada nesse ano, em 1984 a área já voltava ao patamar de seu pico anterior (1982), mantendo-se relativamente estável a partir de então, a despeito da queda verificada nos recursos alocados.

O cenário vivenciado pela agricultura nos anos 80 que, de certa forma, se repetiu no início dos anos 90 , foi de crescimento da produtividade com área relativamente constante, não obstante a escassez de crédito e a conjuntura de preços quase sempre desfavorável ${ }^{1}$.

1 Sobre a situação da agricultura na década de 80 e início da década de 90 , ver, por exemplo, Gonzalez e Costa (1998), Goldin e Rezende (1993), Gasques e Villa Verde (1990), Barros e Manoel (1988) e Rezende (1988 e 1992). 
Essa moldura institucional que pairava sobre a agricultura brasileira no final da década de 80 permeou o estudo de Gonzalez (1990), o qual, analisando as perspectivas para a agropecuária brasileira na década de 90 , concluía que o crédito (ou sua ausência) constituir-se-ia no principal ponto de estrangulamento do setor rural, tanto no aspecto do volume a ser alocado, quanto no aspecto custo. $O$ modelo que então se esgotava necessitava substituição. Na realidade de escassez de crédito via sistema bancário, para que a economia não abandonasse sua dinâmica, começaram a emergir créditos privados, alavancados em mecanismos informais como as operações de escambo (conhecidas no meio agrícola pelo jargão "troca-troca") e contratos a termo (como os da ANEC para a soja verde). A escassez de crédito fazia com que os agentes se movimentassem na busca de alternativas que propiciassem o financiamento privado das safras e da comercialização. Os agentes privados e públicos reforçaram, então, o movimento de busca de novas alternativas de financiamento.

É nesse cenário que, além dos instrumentos citados, surge em 1993 o Certificado de Mercadoria com Emissão Garantida (CM-G) ${ }^{2}$. O CM-G, segundo Franca (1997), é um título mercantil de contrato de compra e venda nas modalidades entrega fisica futura garantida (CMFG) e entrega fisica disponível garantida (CMDG), representando a garantia de entrega e a qualidade do produto negociado. Esse título, negociado exclusivamente em bolsas de mercadorias, podia ser utilizado pela indústria tanto a montante da agricultura, na compra de insumos, matérias-primas e materiais de embalagem, como a jusante, na venda à vista ou para entrega futura de seus produtos industrializados ou semi-elaborados. Era passível de utilização também pelo produtor rural, como forma de captação de recursos para o financiamento de suas atividades.

\footnotetext{
${ }^{2}$ Embora ainda exista, o título encontra-se desativado.
} 
A garantia de entrega estava apoiada em dois pilares básicos: a existência de uma clearing, para liquidação dos contratos, e fiança bancária ou seguro de performance, para emprestar credibilidade ao título (segurança de que a mercadoria fisica seria entregue).

Ainda de acordo com Franca (1997), a partir de dados da Central de Registros, foram negociados, no período de 26/07/93 a 31/12/94, 615 certificados, totalizando US\$ 140.2 milhões, enquanto em 1995 foram negociados 2.984 certificados, totalizando US\$ 4.809,9 milhões. Apesar do aparente sucesso (expressivo crescimento), o certificado está sofrendo solução de continuidade (desde 1996), em função de desentendimentos havidos entre a direção da Central de Registros (clearing do sistema) - que detém o direito de utilização do título - e sua acionista majoritária, a Bolsa de Cereais de São Paulo.

Em iniciativa paralela aos esforços de criação e institucionalização do CM-G o Banco do Brasil (BB), maior alocador de recursos para o setor rural, com o objetivo de superar as dificuldades verificadas na obtenção de funding, realizou estudos que resultaram na proposta de criação da Cédula de Produto Rural-CPR - com as características de título financeiro e de contrato a termo. Com a concordância do poder executivo houve a submissão ao Congresso, na forma de projeto de lei, que o aprovou, transformando-o, assim, na Lei $n^{\circ} 8.929$, de 22/08/94.

Com o advento da Lei que criou a CPR, o BB, nesse mesmo ano, iniciou, de forma experimental, as operações com o novo título. Conforme se vê pela análise da Tabela 1, nesse primeiro momento 121 cédulas obtiveram seu aval, representando um total de R\$ 31,9 milhões. Para a safra 95/96 o valor transacionado foi de R\$ 65,5 milhões, para um total de 792 cédulas, enquanto para as safras $96 / 97$ e 97/973 , o volume de transações giradas pelo BB (principal agente do segmento) atingiu a cifra de R\$ 66,2 milhões, com um total de 922 operações.

\footnotetext{
${ }^{3}$ A safra $97 / 97$ seria aquela que se cumpre integralmente dentro do ano civil.
} 
Tabela 1. CPRs avalizadas pelo Banco do Brasil, por safra (posição 15/07/98)

\begin{tabular}{lrr}
\hline Safra & Valor - R $\$ 1,00$ & Número de títulos \\
\hline $94 / 95$ & 31.898 .757 & 121 \\
$95 / 96$ & 65.521 .887 & 792 \\
$96 / 97$ e $97 / 97$ & 66.233 .306 & 922 \\
$97 / 98$ & 57.331 .844 & 1.197 \\
$98 / 99$ & 1.683 .676 & 8 \\
\hline TOTAL & 222.669 .470 & 3.040 \\
\hline
\end{tabular}

FONTE: BANCO DO BRASIL - Uen Rural e Agroindustrial - GECOM/BBCPR.

Na safra 97/98 o número de transações se elevou para 1.197, enquanto houve um ligeiro declínio no volume financeiro envolvido ( $R$ \$ 57,3 milhões). Os dados para 98/99 registram 8 CPR num total de $\mathbf{R} \$ 1,7$ milhões.

A comercialização antecipada de soja (soja verde) corresponde, segundo Banco do Brasil (s/d, "a"), a $36 \%$ da safra nacional. Por outro lado, Franca (1997, p. 14), citando Canziani, relata que esse mecanismo de comercialização foi responsável, na safra 93/94, por quase um terço da soja produzida no país. Porém, por causa do alto nível de inadimplência observado, esse número acabou se reduzindo a $10 \%$ na safra 94/95. Considerando esse último percentual ter-se-á, para o ano de 1997, em torno de 2,6 milhões de toneladas comercializadas na modalidade "soja verde"(ver Tabela 2). Comparando esse número com os registrados pelo $\mathrm{BB}^{4}$ para CPR de soja $(397,6,168,9 \mathrm{e}$ 54,7 mil toneladas para as safras $95 / 96,96 / 97$ e $97 / 98$, respectivamente), percebe-se que a CPR é um instrumento de comercialização ainda incipiente.

Por outro lado, permeando a atividade rural e afetando a decisão dos produtores, existe a incerteza, que, além da possibilidade de queda na produção devido a fenômenos bioclimáticos, expõe os produtores a outros riscos, dos quais se destacam: a) risco de carência de recursos para o plantio, devido ao substancial afastamento do Governo do

\footnotetext{
${ }^{4}$ O design da CPR previa que ela seria utilizada pelos agentes com aval de uma instituição financeira e registrada na CETIP. No entanto, tem prosperado a modalidade de negociação para validade entre as partes, que se constituem em acordos fechados diretamente entre o vendedor e o comprador, sem interferência/intermediação de terceiros. Neste caso, a CPR estaria funcionando meramente como um substituto para os contratos de soja verde, por exemplo.
} 
financiamento do crédito rural. Esse afastamento propiciou, como alternativa de suprimento de recursos, a criação da "poupança verde" e, em período mais recente, a aprovação da Lei que introduziu a CPR; e b) risco de mercado, cuja redução/eliminação pode ser alcançada através dos mercados futuros, como mecanismo de hedging, ou através do desenvolvimento de um mercado de opções. São instrumentos que podem ser mais eficazes para o produtor e para a sociedade do que o sistema de AGF/EGF ${ }^{5}$, pelos problemas que este apresentou ao longo do tempo e, até mesmo, porque atualmente os recursos oficiais não atendem aos volumes requeridos.

O risco de carência de recursos de que trata o item "a" pode ser amenizado pelos instrumentos formais ou informais ${ }^{6}$ de crédito que têm surgido no mercado e que foram tratados em parágrafos anteriores. Dentre os mecanismos listados insere-se a CPR.

Para o risco de mercado, aqui considerado como risco de preço, os agentes econômicos do meio rural praticamente não têm buscado proteção ${ }^{7}$. Conforme se vê pela análise da Tabela 2, o volume envolvido na transação de cada commodity agropecuária não chega, em nenhum caso, a percentual significativo da safra nacional respectiva, à exceção do café, cujo percentual atingido é de $58,65 \%^{8}$. Nas bolsas internacionais é comum que o volume de transação fisica envolvida eqüivalha a algumas vezes o giro da safra nacional da commodity respectiva. A propósito, Souza $(1994$, p.3) relata que em

\footnotetext{
${ }^{5}$ Sobre os problemas da Politica de Garantia de Preços Mínimos (PGPM), na qual se insere os AGF e EGF, especialmente no caso do milho, ver, por exemplo, Lima e Barros (1996).

${ }^{6}$ Sobre mecanismos informais/alternativos de crédito, ver, por exemplo, Araújo e Almeida (1997) e Marques et al. (1997).

${ }^{7}$ Deve-se qualificar esta questão. Os produtores rurais só vão buscar proteção contra variações de preço na ausência de mecanismos de garantia, como a PGPM, por exemplo. Carlton (1984), p.243/4), bem caracteriza essa questão quando diz que, se o preço de equilíbrio é fortemente influenciado por regulamentação governamental, a probabilidade de se encontrar um mercado futuro decresce dada a rigidez na variação de preços. Se os preços não variam não há razão para se buscar proteção.

${ }^{8}$ Está-se considerando na Tabela 2 apenas os negócios girados internamente. A rigor, para que se tivesse uma idéia real da prática de hedging por brasileinos dever-se-ia considerar, também, os hedges feitos dinetamente em bolsas estrangeiras.
} 
1990 o volume de negociação de soja e milho na Chicago Board of Trade correspondeu a 13,3 e a 7,4 vezes a produção mundial anual, respectivamente'

Tabela 2. Contratos futuros agropecuários negociados na BM\&F e produção nacional (1997)

\begin{tabular}{lrrrrr}
\hline Mercado & $\begin{array}{c}\text { Contratos } \\
\text { Negociados }\end{array}$ & $\begin{array}{c}\text { Volume } \\
\text { Financeiro } \\
\text { R\$ mil }\end{array}$ & $\begin{array}{c}\text { Volume Físico } \\
\text { Envolvido } \\
\text { (a) }\end{array}$ & $\begin{array}{l}\text { Produção } \\
\text { Nacional }\end{array}$ & \multicolumn{1}{c}{$\begin{array}{c}\text { \% } \\
\text { a } \mathbf{b}^{*} 100\end{array}$} \\
\hline Açúcar Cristal & 8.330 & 34.133 & 112.455 & 13.596 .812 & 0,83 \\
Algodão & 13.689 & 115.727 & 62.092 & 831.755 & 7,47 \\
Boi Gordo & 109.261 & 948.964 & 540.842 & 6.196 .000 & 8,73 \\
Café Arábica & 114.521 & 2.474 .206 & 687.126 & 1.171 .552 & 58,65 \\
Millho & 18.907 & 70.573 & 510.489 & 34.601 .865 & 1,48 \\
Soja & 16.082 & 108.615 & 434.214 & 26.430 .782 & 1,64 \\
\hline
\end{tabular}

FONTE: Resenha BM\&F n 121, Levantamento Sistemático da Produção Agrícola-BBGE, Agrianual 99 e Anualpec 98 (cálculos do autor).

a: embora pouco convencional, para uniformidade e facilidade de comparação, todas as medidas foram transformadas em toneladas méricicas e assim encontram-se expressas.

Adicionalmente, a busca de proteção contra risco de preços através do mercado de opções é praticamente inexistente no Brasil. Apenas duas commodities agropecuárias oferecem possibilidade de negociação: café e boi gordo. Para a primeira foram negociados 3.210 contratos de opção em 1997, enquanto para boi gordo ocorreram apenas 392 negócios (Resenha BM\&F, 121, p.107).

Os números apresentados evidenciam, ainda, um outro fato: mesmo que a modalidade de cross hedging ${ }^{10}$ venha sendo exercida na bolsa brasileira, seu movimento deve ser praticamente nulo, dado que o número de contratos negociados em todas as commodities agropecuárias é substancialmente baixo.

\footnotetext{
${ }^{9}$ É de se ressaltar que girar várias vezes a safra nacional em mercados com alta liquidez não se constitui uma surpresa. A mecânica usual de operações nesses mercados é a liquidação de um contrato através de uma operação inversa. Nesse caso, para uma única operação de hedging vão existir dois contratos. Entrando-se e saindo-se do mercado várias vezes, o número de contratos (com seu equivalente em produção) cresce significativamente.

10 O cross-hedging refere-se à proteção de uma posição através de uma commodity diferente daquela mantida no fisico, porém com preços relacionàdos. Por exemplo: porco e milho.
} 
É nesse contexto de baixa utilização de mecanismos de proteção que também se insere a CPR. Esse título, além de servir como instrumento de captação de recursos tem, também, o papel de servir como hedging de venda ${ }^{11}$ uma vez que, ao ser emitido, o preço da commodity sob negociação é travado, tornando-se uma proteção contra movimentos de baixa dos preços.

Se o preço presente líquido da CPR (já deduzidos os custos), formado a partir das expectativas de preço futuro, for favorável à operação, do ponto de vista do hedging, tornar-se-á até mais interessante do que uma transação em mercados futuros, uma vez que no mercado a termo não há disponibilização de margem de garantia (com seus custos implícitos) e não há, também, o risco de se incorrer em ajustes diários para acerto de posição. Além disso, não há custos de monitoramento do mercado para se determinar o momento a sair da posição.

Do ponto de vista de sua conceituação, a CPR pode beneficiar quaisquer produtos agropecuários "in natura", beneficiados, ou industrializados, que tenham sido produzidos por produtores rurais ou suas cooperativas. Assim, as partes naturais envolvidas nas transações são os produtores, os beneficiadores, a agroindústria ou as tradings. No entanto, se os negócios ficarem limitados apenas entre a ponta compradora e a vendedora, o título vai padecer do velho problema de se encontrar - para um determinado produto com determinada qualidade, quantidade e preço - algum comprador que esteja necessitando de produto exatamente com as mesmas especificações.

Qual é uma das grandes vantagens dos mercados futuros? Exatamente a estandardização, que permite que se transacione uma mercadoria "padrão", independente do nível de tecnificação do produtor, de sua realidade sócio-econômica ou da região onde

\footnotetext{
${ }^{11}$ O comprador da CPR pode proteger-se contra oscilaçōes dos preços através de contratos a termo, futuros ou opções, de forma a neutralizar eventuais riscos de sua posição long em CPR.
} 
estão localizadas suas lavouras. Com essa mercadoria padrão interagem no mercado os hedgers, os especuladores e os arbitradores. É reconhecido na literatura que são justamente esses dois últimos agentes que dão liquidez ao mercado e que viabilizam a existência de um determinado contrato. Assim, quanto mais agentes externos houver transcendendo a relação vendedor/comprador - interessados no produto físico em si, mais chance de êxito a CPR apresentará.

Dessa forma, cumpre entender as interações que a CPR pode manter com os mercados futuros e de opções e a resposta que o mercado vem apresentando em sua utilização. Da realidade que se observar, talvez seja o caso de se acrescentar ao instrumento características que aumentem sua atratividade e que permitam aos investidores a opção de aplicar seus recursos em commodities agropecuárias. Investidores externos ao setor agropecuário certamente não têm interesse no recebimento dos produtos comercializados. As alternativas passam, então, pela eliminação da possibilidade de recebimento do produto fisico. Essa possibilidade dar-se-ia pela existência de um mercado secundário movimentado ou, até mesmo, pela possibilidade de a CPR poder ser liquidada com base em indicadores de preços ${ }^{12}$, a exemplo dos contratos futuros das commodities agropecuárias que hoje são assim referenciados.

Além da atratividade para os investidores, cumpre acrescentar maior atratividade para os vendedores ${ }^{13}$ e compradores. Para ambas categorias de agentes o risco de preço está firmemente presente. Para os vendedores apresenta-se o risco de o preço, no período

\footnotetext{
${ }^{12}$ Enquanto se pensava nessa altemativa, Branco (1997, p.c7), em artigo na Gazeta Mercantil, estampava uma reportagem intitulada "A moeda do campo sai do forno", onde dá conta de que a Bolsa de Mercadorias e de Futuros (BM\&F) prepara o lançamento de uma modalidade de CPR com opção de liquidação financeira, podendo ser esta a solução para a escassez de mecanismos de compra e venda futura de safras, conforme crença exposta na reportagem.

13 Um aspecto que certainente deve ser considerado é a questão cultural. Um trabalho educativo mereceria ser levado a efeito, instrumentalizando os produtores rurais a lidar com essa nova realidade que lentamente chega ao campo. No caso específico da CPR, duas são as variáveis principais: a) apreender o sentido e aferir a adequação dos deságios praticados em relação ao preço futuro, uma vez que a renda da produção vendida é recebida de imediato; b) na comparação com o preço praticado na época da colheita, comparar esse valor não com o valor nominal obtido na época de emissão da CPR, mas, sim, com esse valor, acrescido dos custos financeiros projetados até a data normal de comencialização, acrescido do custo de oportunidade de ficar sem plantar a safra.
} 
de entrega do produto, estar em patamar real ou nominalmente superior ao transacionado. Tal fato poderia induzir a não-entrega ou ao sentimento de se ter incorrido em perdas ${ }^{14}$. Para os compradores o risco seria o inverso. Para esses dois agentes, poderse-iam modelar operações conjugadas com os mercados futuros e de opções, de forma a minimizar a variância de preços contrária às posições assumidas.

Aparentemente ambas as sistemáticas (CPR e futuros/opções) são complementares. Implicam em que o desenvolvimento e o fortalecimento de uma pode favorecer o desenvolvimento e o fortalecimento da outra e vice-versa. Além disso, as necessidades pressionaram por mudanças. Com o cenário de escassez de recursos cada vez maior, o Governo também tenta, no mercado de derivativos, aumentar sua eficiência nas políticas públicas. Nesse contexto, lançou um programa de venda de opções de venda, com o qual quer substituir, pelo menos em parte, a PGPM.

A maturidade dessa linha de alternativas, a engenharia financeira que as une e a resposta dos agentes econômicos vão lançar luz sobre a questão de se o mercado financeiro brasileiro tem, efetivamente, condições de responder às necessidades do campo na proteção de preços e na geração do funding necessário à implantação/condução das lavouras.

\subsection{Objetivos}

Ao início das leituras sobre o tema CPR, sentiu-se a falta de uma melhor caracterização a respeito desse título. Não estava claro tratar-se de um contrato a termo, assim como não estava bem definida sua inserção no campo desses contratos e dos

14 Do ponto de vista especifico de "qual o preço justo", ajudaria muito a elaboração e divulgação de modelos preditores de preços, ou, alternativamente, alguma forma de liquidaça financeira do título. Além disso, como os produtores rurais são tomadores de risco en potencial (sempre têm a esperança de que o preço vai subir) a CPR poderia, ainda, ser transformada em título pós-fixado, do ponto de vista do preço praticado. 
derivativos agropecuários. Além disso, cumpria verificar quais as principais diferenças/ semelhanças entre os contratos a termo e os contratos futuros.

Dessa forma, um dos objetivos deste trabalho foi o de buscar lançar luz sobre as questões levantadas. Assim, tratou-se de caracterizar, nas seções 2.2 e 2,3, através de pesquisa teórica ${ }^{15}$, os ambientes contratual e operacional que emolduram a existência da CPR e nos quais ela está inserida.

Além da questão acima e das considerações iniciais, situando o problema, quando se pensa em estender ao campo mecanismos de proteção de preços, seja com entrega física, como é o caso da CPR, seja na transação com papéis (principalmente nesta situação), como são o caso dos contratos futuros e de opções, há sempre que se considerar: a) a questão cultural, ou seja, como os agricultores encaram a transição do exercício de práticas tradicionais (plantar com financiamento bancário e comercializar após ter o produto colhido) à adoção de instrumentos alternativos; b) a sensação de que o preço obtido com a venda do produto através de CPR é baixo, uma vez que o preço futuro é trazido a valor presente, situando-se nomalmente abaixo do preço no disponível; c) o medo de que os preços se elevem após a venda, perdendo-se a oportunidade de apropriação desses ganhos; e d) ausência de um mercado secundário movimentado para as CPR.

O segundo objetivo deste estudo, portanto, foi a aferição do sentimento dos produtores que praticaram venda antecipada de café, nas safras 96/97 e 97/98, através de CPRs intermediadas pelo Banco do Brasil. Buscou-se a opinião dos emissores de CPR acerca do título e de eventuais transações nos mercados futuros e de opções. Para a consecução deste objetivo realizou-se pesquisa de campo, cujos resultados encontram-se descritos no capítulo 5 .

\footnotetext{
${ }^{15}$ A pesquisa teórica para Ferrari $(1982$, p.169) tem por finalidade melhorar o próprio conhecimento, o que significa o desenvolvimento de métodos, técnicas e procedimentos que permitam alcançar diagnósticos cada vez mais acurados sobre os problemas, ou de estudá-los mais adequadamente.
} 
O último objetivo específico do trabalho foi o de mensurar os resultados da CPR enquanto instrumento de financiamento e como altemativa de hedging. Os resultados obtidos encontram-se no capítulo 6.

Em decorrência desses objetivos específicos, o objetivo geral foi o de levantar um arcabouço teórico e prático que possibilitasse, a partir do estudo, a otimização do uso da CPR, conjugada com um maior desenvolvimento dos derivativos agropecuários. Tais derivativos devem ter como pressuposto básico a diminuição/eliminação de riscos de preços e a possibilidade de se obter funding para a implantação de lavouras e a comercialização de produtos de origem rural.

\subsection{Organização do trabalho}

O trabalho, em sua introdução, buscou situar o problema para o qual o esforço da pesquisa foi dirigido, a ilustração dos objetivos que se pretendia com a mesma e, nesta seção, o delineamento das partes que o compõe. Assim, os capítulos 2 e 3 foram reservados à revisão da literatura. No capítulo 2 , é apresentado o arcabouço teórico que dá sustentação aos mercados a termo e à Cédula de Produto Rural. No capítulo 3, por sua vez, são apresentadas as ligações teóricas que dão sustentação à interrelação da CPR com os mercados futuros e de opções, como, por exemplo, a fundamentação econômica desses mercados, os conceitos de base, de liquidação financeira, de proteção contra risco e a questão da substitutibilidade entre os contratos a termo e futuros.

O capítulo 4 trata da apresentação da metodologia aplicada, necessária ao cumprimento dos objetivos propostos. No capítulo 5 é feita a análise e discussão dos resultados oriundos da pesquisa de campo, enquanto no capítulo 6 é feita a avaliação da CPR como alternativa de financiamento e como instrumento de hedging. Finalmente, no 
capítulo 7, são arroladas as conclusões a que se chegou com o trabalho e indicadas alternativas para pesquisas complementares. 


\section{O MERCADO A TERMO E A CÉDULA DE PRODUTO RURAL}

\subsection{Agropecuária e Risco Econômico}

Se comparada à indústria, com sistema de fluxo contínuo e possibilidades de especialização na produção, melhor divisão do trabalho etc, a atividade agropecuária é cercada por situações que a transformam em um sistema peculiar de produção.

A qualidade das terras e de relevo em geral não são uniformes, incorporando descontinuidades no processo de produção. Esses fatores fazem com que as culturas sejam alteradas de acordo com a melhor adequação ao relevo ou, ainda, em relação à qualidade dos solos, impondo elevação de custos pela redução das economias de escala derivadas da melhor utilização e especialização da mão-de-obra e da maquinaria.

Dessa forma, as peculiaridades de localização (qualidade de solos, relevo e proximidade dos centros consumidores) condicionam as decisões em relação ao que, quanto e como produzir. Ao tomar a decisão o produtor vai levar em conta a adaptabilidade das culturas em função de seu potencial econômico e das condições existentes para o escoamento da produção ${ }^{16}$.

Por outro lado, a característica física da agricultura, de sistema de produção em estágios diferenciados no tempo (preparo do solo, plantio, crescimento vegetativo e

${ }^{16}$ Além do diferencial de preços derivados da maior ou menor proximidade dos centros consumidores e dos sistemas de transporte, quanto mais distamte e quanto maiores forem as difculdades de escoamento da produção surge a possibilidade da existencia de agentes intermediários que vão atuar na compra da produção e no fornecimento de insumos como monopolistas/monopsonistas, apropriando-se de parte da renda dos produtores (Accarini, 1987, p.31). 
colheita), impõe descontinuidade no fluxo de produção, ocasionando ociosidade temporária de terras, armazéns, mão-de-obra e maquinaria e elevando o custo financeiro implícito. Torna, dessa forma, mais lento o retorno dos investimentos no setor. Além disso, como a oferta de produto nas culturas de larga escala se dá toda praticamente ao mesmo tempo - no período da safra - os preços se deprimem e os custos de armazenagem e transporte se elevam, afetando a renda do produtor.

Não bastassem as características do sistema produtivo e os efeitos da sazonalidade da produção, a demanda, geralmente inelástica a variações de preço, também atua sobre a capacidade de formação de preço nas épocas de colheita, afetando, também por esse lado a renda do produtor.

De forma paralela aos aspectos econômicos que cercam o sistema produtivo, paira, ainda, sobre a agricultura a ameaça de ocorrência a qualquer instante de fenômenos climáticos adversos ou infestação de pragas ou doenças que podem comprometer (algumas vezes de forma irreversível) o esforço produtivo, afetando os custos e os investimentos realizados no aparelhamento da atividade.

A possibilidade de ocorrência desses eventos, aliada à (in)capacidade de financiamento do produtor, muitas vezes vai determinar o nível de tecnologia que ele vai empregar em sua produção. Em muitos momentos a opção será por técnicas menos aprimoradas e dispendiosas.

Embora, de um modo geral, as decisões intertemporais sejam baseadas no conhecimento dos aspectos econômicos que cercam a realidade do ambiente na época da decisão, especialmente as taxas de juros que vigoram na economia, o produtor, mesmo percebendo uma relação desvantajosa, decide levar avante seu projeto de cultivo, contrastando-o com o custo de oportunidade de não fazê-lo. Quanto lhe custa deixar os campos sem semear, a mão-de-obra e a maquinaria paradas? De onde retiraria renda para 
seu sustento ${ }^{17}$ Além disso, quais as oportunidades de mudar de cultura ou, até mesmo, de abandonar o campo em favor da cidade?

Vistas as questões acima, ou seja,

"o fato de a produção sujeitar-se aos riscos de mercado resultantes de possíveis reduções bruscas de preços na época da colheita e aos riscos associados à possibilidade de ocorrência de fenômenos bioclimáticos adversos, imprevisíveis e/ou incontroláveis pelo homem, não é dificil chegar à conclusão de que a atividade rural tende a propiciar baixo retorno e elevado risco quando comparada com outras atividades econômicas" (Accarini, 1987, p. 37).

Assim, conclui-se que, dentre os setores da economia, sem dúvida o que apresenta maior risco é o setor rural. Dois são os riscos que, se não contornados de alguma forma, inibem seriamente os investimentos no campo. São eles: risco de produção e risco de mercado.

O primeiro está intrinsecamente ligado às condições climáticas e à possibilidade de ocorrência de pragas e doenças. $O$ segundo, deriva do fato de a decisão de investir ser bastante anterior ao momento da colheita, ocasião em que as condições de mercado podem encontrar-se radicalmente diferentes.

Os riscos inerentes à atividade agropecuária tornam a incerteza presente. na atividade agropecuánia. Essa incerteza, que caracteriza todas as transações futuras de bens e serviços, é, por sua vez, bastante relevante em economia.

\footnotetext{
${ }^{17}$ Sobre as dificuldades que principalmente os pequenos produtores se defrontam na obtenção de renda, cabe uma comparação com a realidade que Gonzalez (1989) encontrou ao estudar o setor informal Naquele trabalho foi detectado que, mesmo no segmento que denominou "infornal compulsório", algumas unidades podem apresemtar evolução desde que tenham vocação e aspirafão ao crescimento e indaga (p.46): como isto seria feito, se a renda gerada na atividade permite, em princípio, apenas a subsistência? Sua resposta envolve não a acumulação através de excedentes, como é de praxe, mas sim, a incorporacão de maior oferta de trabalho envolvendo toda a unidade familiar, gerando uma poupança forçada obtida às custas de um subconsumo presente, trocado pela possibilidade de algum consumo no futuro.
} 
No caso específico dos produtos agropecuários, os mercados intertemporais funcionam no sentido de alocar, entre os consumidores, os produtos ofertados pelos produtores. No entanto, como existem falhas no mercado, não se sabendo, ex ante, os estados do mundo que irão ocorrer no futuro, desconhece-se a estrutura de receitas com a qual se poderá contar. Os agentes são motivados, então, a desenvolver instrumentos que possam distribuir ou reduzir tanto os riscos de produção, com os seguros de performance, como os riscos de preço através de contratos a termo ou de instrumentos derivativos.

\subsection{O Mercado A Termo}

Os contratos a termo, instrumentos que dão forma ao mercado de mesmo nome, já foram muito confundidos com os contratos futuros (Black, 1976; Cox et al., 1982). Para estes últimos autores, grande parte da literatura tratou os mercados futuros e a termo como se fossem sinônimos e, para muitos agentes, a diferença constituir-se-ia de detalhes administrativos irrelevantes e agia-se pensando que os dois cumpriam a mesma função econômica.

Neste capítulo tratar-se-á dos mercados a termo, enquanto no próximo serão abordados os aspectos conceituais inerentes aos mercados futuros que guardam correlação com o tema deste trabalho. No entanto, como os dois se relacionam, também aqui serão abordados aspectos que os diferenciam. Para Leuthold et al. (1989, p.25), "contratos futuros e a termo são acordos entre duas partes para entregar ou receber um bem ou serviço particular em uma data futura por um dado preço". Ou seja, ambos expressam a performance contratualmente diferida e especificam os termos básicos contidos no mesmo. A natureza básica de ambos certamente é que favorece a possibilidade de confusões conceituais.

A principal diferença entre os dois tipos consiste no fato de que nos mercados futuros trabalha-se com uma determinada commodity como referencial, não se estando 
interessado no recebimento ou entrega do produto físico em si, apenas em seus movimentos de preço, os quais vão balizar decisões estratégicas dos agentes que têm como negócio (venda ou compra) a mercadoria objeto do contrato futuro.

Com relação à dicotomia existente entre os contratos a termo e os contratos futuros, várias são as diferenças entre ambos, conforme se pode perceber pela análise do Quadro 1, o qual sintetiza as principais características de cada um desses contratos.

Quadro 1 - Diferenças entre os contratos a termo e futuros

\begin{tabular}{l|l}
\hline CONTRATOS A TERMO & CONTRATOS FUTUROS \\
\hline $\begin{array}{l}\text { normalmente firmados de forma privada } \\
\text { entre o vendedor e o comprador; }\end{array}$ & $\begin{array}{l}\text { celebrados de forma aberta em } \\
\text { ambientes públicos e organizados } \\
\text { (bolsas); }\end{array}$ \\
- normalmente mantidos pelas partes \\
$\begin{array}{l}\text { intervenientes até o vencimento; } \\
\text { normalmente o mercado apresenta } \\
\text { liquidez, facilitando a entrada e a saída; } \\
\text { possui características próprias ou } \\
\text { necessárias à satisfação de necessidades } \\
\text { quantidade, qualidade, local e época de } \\
\text { específicas; }\end{array}$ & $\begin{array}{l}\text { entrega; } \\
\text { comercializados em ambientes de regras } \\
\text { estáveis com a performance garantida } \\
\text { por câmaras de compensação; }\end{array}$ \\
$\begin{array}{l}\text { comercialização do contrato; } \\
\text { - a maioria dos contratos é liquidada } \\
\text { mediante a entrega fisica; }\end{array}$ & $\begin{array}{l}\text { a maioria dos contratos é liquidada antes } \\
\text { do vencimento por operações inversas; } \\
\text { além dos vendedores e compradores } \\
\text { naturais, participam do mercado os } \\
\text { especuladores e os arbitradores; } \\
\text { requerem o depósito de margens de } \\
\text { garantia e apresentam custos diretos de } \\
\text { transação (corretagem e taxas das } \\
\text { bolsas). }\end{array}$ \\
\hline $\begin{array}{l}\text { normalmente não apresentam custos de } \\
\text { corretagem e não requerem depósito de } \\
\text { margens de garantia. }\end{array}$ &
\end{tabular}

FONTE: elaborado pelo autor, de forma adaptada, a partir de Leuthold et al. (1989)

Os contratos a termo são usualmente firmados para entrega e liquidação financeira diferidas. Podem ser classificados, basicamente, de duas formas quanto aos preços: a) preços de liquidação estabelecido no ato da firmatura do contrato; ou b) preço a fixar. Além disso, segundo Marshall $(1989$, p.25), os preços futuros de um contrato a 
termo são estabelecidos no ato de sua firmatura. Esses preços podem ser estabelecidos na forma de preço fixo por unidade ou referenciado em uma commodity relacionada em algum outro mercado ${ }^{18}$. Segundo a experiência daquele autor não é incomum que o contrato a termo para uma dada qualidade de trigo seja vinculado à qualidade padrão comercializada no mercado futuro.

A CPR é uma variação das modalidades tradicionais de contrato a termo. É um contrato com entrega diferida, com preço fixado quando da concretização do negócio e quitação financeira também nesse momento.

A prática de se estabelecer monetariamente o preço futuro a vigorar em um dado contrato a termo esbarra, em países como o Brasil, na memória inflacionária causada por muitos anos de elevação persistente do nível de preços da economia e de estes terem alcançado em alguns períodos taxas anualizadas superiores a $1.000 \%$ (1.783\% em 1989, por exemplo). Além disso, a legislação brasileira não permite que os contratos sejam referenciados em moeda estrangeira ${ }^{19}$.

Se há resistência à aceitação de preços fixos e se estes não podem ser referenciados em moeda estrangeira, está criado o impasse. A alternativa seria, então, alguma coisa semelhante ao mecanismo existente no Brasil para os mercados futuros, onde a liquidação dos contratos é baseada em uma unidade denominada "ponto", equivalendo, no entanto, cada ponto a US\$ 1,00, cuja transformação em moeda nacional é realizada pela cotação comercial de venda divulgada pelo Banco Central (transação PTAX800).

\footnotetext{
${ }^{18}$ Este procedimento lembra 0 cross hedging que consiste na tomada de uma posição em contrato futuro em ativo distinto daquele que se detém posição no fisico, porém relacionado à mercadoria cuja posição se quer proteger, por inexistência de um contrato futuro próprio.

${ }^{19}$ Além da questão inflacionária, Frick $(1996$, p.35) adiciona que o risco de uma entrega não desejada e os custos impostos pela tributaçăo incidente na negociação de produtos agropecuários inibem a participação de operadores habituados às operaçðes com títulos do governo e, por extensão, dos tomadores de risco de um modo geral.
} 
Uma outra alternativa seria manter fixa a quantidade de produto, estabelecendose uma faixa de variação para os preços, deixando-os, porém, para determinação final após a colheita em período ajustado entre as partes. A prática que vigorou para os contratos de laranja talvez pudesse ser aplicada de forma exitosa ${ }^{20}$.

Ainda com relação às diferenças entre contratos a termo e futuros, uma entidade com atuação fundamental na liquidez do mercado e na integridade das transações é a câmara de compensação (clearinghouse). Segundo Leuthold et al. (1989, p.37), a câmara de compensação é responsável por: a) fazer a compensação das transações ocorridas; b) assegurar a integridade financeira das transações; e c) propiciar os meios para a liquidação fisica (quando for o caso).

A literatura reconhece que o papel dessa entidade é crucial para a existência do mercado e para o êxito das transações. São as câmaras de compensação que garantem o cumprimento dos contratos e transmitem a certeza de que os agentes creditados pelo processo de ajustes diários irão efetivamente receber os valores a que fazem jus. Com sua atuação asseguram as condições para a livre entrada e saída do mercado, o que no dizer de Edwards ${ }^{21}$ (Forbes, 1994, p.26), "transforma o que não passaria de simples contrato a termo em contratos futuros de alta liquidez".

Não obstante as diferenças apontadas, um contrato a termo pode revelar-se em benéfico e adequado instrumento de comercialização e planejamento da produção por permitir - uma vez que envolve a mercadoria fisica - tanto aos compradores quanto aos vendedores planejar adequadamente a utilização das instalações de armazenamento e processamento e, assim, cumprir etapas programadas de produção. CBOT (1985, p.15) exemplifica as vantagens da seguinte forma: se um moinho de trigo se encontra com sua capacidade de estocagem esgotada, ao efetuar compras a termo terá garantido as fontes

\footnotetext{
${ }^{20}$ Sobre a precificação dos contratos de laranja, ver Maia (1992).

${ }^{21}$ Edwards, Franklin R. The Clearing Association in Futures Market. The Journal of Futures Markets, 3(4), 1983.
} 
de abastecimento, porém com o recebimento diferido do produto até o momento em que possa processá-lo.

Como o pano de fundo de um contrato a termo consiste em achar um comprador para um vendedor (ou vice-versa), para uma dada mercadoria e a um dado preço, este tipo de contrato apresenta um alto grau de flexibilidade em seu desenho, mostrando-se bastante adequado às transações por permitir às partes ajustá-lo conforme seus desejos e obtendo, assim, a combinação de termos ideal para melhor adequação à necessidade de ambos os agentes (vendedor e comprador). $\mathrm{Na}$ verdade, constituem-se em contratos tailor made.

Como os contratos a termo normalmente consistem de uma relação direta entre o comprador e o vendedor, com o objetivo primordial de entrega/recebimento do produto físico objeto do contrato, seu cancelamento vai depender do consentimento de ambas as partes. Essa característica não só limita a liquidez, como também dificulta a saída em casos de desinteresse em se continuar com a posição assumida. Além disso, permite o surgimento de todos os problemas relativos a contratos diagnosticados pela Economia dos Custos de Transação, especialmente o comportamento oportunista ${ }^{22}$.

Um produtor rural ao participar tanto de um mercado a termo quanto de um mercado futuro deve ter, como objetivo, o melhor escoamento de sua produção e a obtenção de instrumentos que permitam contraposição à lógica natural apresentada pelo comportamento dos preços agrícolas de se apresentarem altos fora dos períodos de colheita e baixos durante e logo após esse evento. Deverá lembrar, contudo, que em um contrato a termo o envolvimento financeiro ocorrerá nas épocas e montantes previstos no contrato, enquanto no mercado futuro - além das margens de garantia -, ocorrendo

\footnotetext{
${ }^{22}$ Para Williamson (1985, p.47), oporturismo é a busca do auto-interesse com astúcia. O oportumismo inclui as formas mais flagrantes como mentira, furto e trapaça. De forma mais frequiente, porém, envolve formas sutis de engano. Incluem-se tanto as formas ativa como passiva, além de situaçóes ex ante e ex post. $O$ autor distingue três níveis de auto-interesse: o oportunismo, forma mais forte e objeto da economia dos custos de transafäo; a simples busca do auto-interesse, forma média, componente da análise neoclássica e a obediência, como forma fraca ou nula.
} 
variações de preço contrárias à posição assumida, ocorrem os ajustes diários implicando em desembolsos em favor da parte contrária.

Nos mercados futuros, por serem comercializados contratos definidos a partir de uma mercadoria-padrão, todos os ajustes em relação à entrega física (que quase nunca ocorre) são feitos em relação a esse padrão. No entanto, para os contratos a termo, por envolver um ajuste específico entre vendedor e comprador, normalmente são previstos ágios para as mercadorias que apresentem qualidade superior à acordada e deságios, em caso contrário.

As características dos contratos a termo e futuro são muitas vezes semelhantes, até porque estes últimos derivaram-se dos primeiros. Uma grande diferença entre ambos se dá em nível de facilidade de se encerrarem as posições, permitindo que terceiros agentes (os especuladores) participem do mercado. Por não estarem interessados no produto físico, os especuladores, desde que não tenham que receber o produto, vão tomar riscos de variações de preços, sempre na esperança de obterem lucros. Com esse procedimento, aumentam a liquidez do mercado tornando-o mais atrativo para os vendedores e compradores da mercadoria spot (hedgers).

Para Leuthold et al. (1989, p.26), os contratos futuros e a termo são complementares, porém não são substitutos perfeitos ${ }^{23}$ devido a características específicas, diferenças na forma de pagamento e nos padrões de ajuste, as quais geram diferentes fluxos de receita e diferentes riscos de base ${ }^{24}$.

Para esses autores, contratos a termo com preços fixos não apresentam risco de base, existindo com o propósito da entrega física a um preço já fixado, com qualidade e local de entrega também já definidos. Esses elementos podem diferir das especificações

\footnotetext{
${ }^{23}$ A questão da substitutibilidade entre os contratos é tratada na seção 3.1.6.

${ }^{24}$ Como será visto adiante, base é a diferença entre o preço à vista e o preço futuro de uma mercadoria. A não convergência entre esses preços provoca o que é chamado risco de base.
} 
dos contratos futuros. Estes últimos oferecem flexibilidade e liquidez para se desfazer posições futuras com reflexos nos custos de transação, nos prêmios e nos custos de pesquisa. Embora divergentes, os contratos futuros e a termo freqüentemente coexistem para muitos bens e serviços.

No caso específico do Brasil, com o esgotamento da capacidade do Estado em alocar recursos suficientes para o financiamento das safras e para dar prosseguimento, de forma efetiva, à política de garantia de preços mínimos (PGPM), começaram - como já visto anteriormente - a surgir e a ganhar importância mecanismos alternativos aos instrumentos tradicionais, como foram o caso das transações denominadas "troca-troca" e dos contratos de "soja verde".

Os contratos "troca-troca", muito utilizados pelas cooperativas e fornecedores, consistiam, de um modo geral, em entregar para o produtor rural os insumos de que necessitavam mediante a entrega futura, como pagamento, de determinada quantidade de sacas de produto (operações de custeio). Nas necessidades de investimento, o procedimento era similar, transformava-se o valor da máquina/equipamento em prestações, baseadas em determinada quantidade de produto, surgindo o valor a ser amortizado em cada safra. Essa foi uma das respostas que o mercado encontrou para suprir a ausência/insuficiência de crédito rural oficial.

No segmento de soja, tornaram-se muito comuns os contratos de soja verde firmados pelos produtores em favor, principalmente, de exportadores individuais e de tradings. $\mathrm{O}$ produtor, necessitando recursos para implantar sua lavoura, vendia antecipadamente sua safra.

Esses contratos altemativos, gerados pelo mercado, propiciavam dois tipos principais de problemas: a) qual o deságio a ser aplicado para definir a quantidade de produto equivalente a ser entregue pelo produtor; e b) ausência de mecanismos de proteção contra riscos de produção e risco de entrega (inadimplência) pelo produtor. 
O primeiro dos problemas causou prejuízos a muitos produtores, mercê dos altos deságios praticados e, na realidade, da pouca habilidade exibida para mensurar os reflexos dos deságios assumidos. Há ainda que se considerar que nos contratos a termo o deságio tende a ser ampliado em relação ao mercado futuro, pois maior é a incerteza no momento da formação do preço. Aqui, uma das causas que permitem a prática de altos deságios é o fato de os mercados a termo não se constituírem em bons difusores dos preços praticados, uma vez que os preços acordados têm caráter particular, circunscrevendo-se aos dois agentes intervenientes (comprador/vendedor). No caso específico da CPR esse problema é atenuado, uma vez que muitas das transações são levadas a efeito através de leilões eletrônicos e, também, porque os títulos são registrados na CETIP (Central de Custódia e Liquidação Financeira de Títulos).

Além disso, como os contratos a termo exibem dificuldades para serem trocados de mão, pelas especificidades que os cercam (não padronização, data específica de entrega, entrega e acerto financeiro no final etc), a formação de preços entre os intervenientes se dá de uma forma mais rígida, até mesmo pela dificuldade de existência de mercado secundário. Fica-se preso à operação até o seu vencimento. A falta de especuladores que tomem o risco dos hedgers faz com que o mercado secundário deixe de existir ou tenha pouca liquidez, justamente por falta de parceiros (Bessada, 1995, p.98/9).

Ligado a essa questão, Nuevo (1996, p.29) cita que para Lopes os maiores problemas que devem ser saneados no mercado primário e que impedem o desenvolvimento do mercado secundário de títulos lastreados em produtos agrícolas, são: falta de qualidade e tecnologia nos serviços de armazenagem; o fato de os contratos de depósito não serem equilibrados na preservação dos direitos dos depositantes e depositários e a falta de fiscalização dos armazéns gerais por parte das juntas comerciais, levanto a práticas lesivas ao interesse dos depositantes de produto. 
O segundo dos problemas apontados causou, principalmente nas cooperativas, abalos financeiros, seja pela inadimplência, seja porque tais entidades captavam recursos de curto prazo (a um custo financeiro elevado) e os imobilizavam em retornos incertos e de prazo longo.

Além disso, principalmente do ponto de vista de inadimplência por parte do produtor, contratos a termo favorecem o que a Economia dos Custos de Transação qualifica de "comportamento oportunista". Espera-se, inclusive, que os contratos a termo sejam mais suscetíveis a incertezas comportamentais pois não contam com os mecanismos de garantia característicos das bolsas (clearinghouses, que determinam margens, garantias e ajustes diários). A existência desses mecanismos garante maior proteção ao risco de crédito (Lazzarini, 1996, p.97/8).

De forma complementar aos dois problemas considerados, os contratos alternativos ainda apresentam problemas decorrentes de variações de preços (quando estes tenham sido fixados), falta de liquidez (não há terceiros interessados em assumir as posições, mesmo com o objetivo de lucro ao trocar de posições logo após intermediação). Adicionalmente, esses contratos são firmados em "mercados de balcão", no qual a informação é privilégio normalmente do agente mais forte envolvido na negociação. Não há regras e normas preestabelecidas que circunscrevam as negociações. Prevalece, normalmente, o poder do mais forte e, além disso, o preço formado não é disseminado para a sociedade, permanecendo como uma característica privada da transação efetuada (Soboll, 1996).

Também não há, para esses contratos, a figura da clearinghouse, instância de administração de garantias e liquidação de negócios. A existências das clearings reduz os custos de arbitramento das divergências eventualmente verificadas que, sem sua existência, devem ser dirimidas pela justiça. 
Nuevo (1996, p.22/3) expõe outros problemas ligados aos contratos a termo que têm vigorado na agricultura brasileira. Eles são normalmente baseados no código comercial e seguiriam as seguintes características: para acolhimento de garantia hipotecária (quando o caso) há necessidade de formalização através de escritura pública, onerosa e complicada; não permite ao credor transferir seus direitos para terceiros, exceto se realizado através de escritura pública; quando a garantia é fiança, exige-se contrato à parte entre fiador e afiançado; a execução judicial do vendedor, em caso de inadimplemento, é feita através de ação ordinária, de tramitação demorada; não permite a inclusão de seguro contra frustração de safra e não viabiliza a criação de mercado secundário e nem a comercialização em bolsa de mercadorias.

Retornando à questão mais geral, quando um produtor vende sua produção ou parte dela através de contratos a termo, esse contrato, caso os preços caiam, está na verdade lhe servindo de hedging de venda ${ }^{25}$. No caso de elevação de preços, o produtor seria tentado a não entregar o produto, tornando-se, portanto, inadimplente.

Entre as alternativas para se beneficiar de aumentos de preços estaria a assunção de posição comprada no mercado futuro ou, ainda, a aquisição de opção de compra por um preço de exercício financeiramente equivalente ao preço obtido na CPR. No primeiro caso o produtor receberia ajustes diários, enquanto no segundo compraria o produto (no caso de opção sobre o físico) ao preço de exercício e o venderia ao preço de mercado, beneficiando-se do diferencial de preços.

Posição em opções poderia perfeitamente complementar a venda com CPR. Tanto é que Lence et al. (1994), ao estudar niveis ótimos de hedging o fazem através de contratos a termo e de op̧̧ões ao invés de contratos futuros. Para esses autores, o nível ótimo de insumos (e portanto de produção) é determinado separadamente a partir do

\footnotetext{
${ }^{25}$ Assim como serve ao produtor como proteção contra baixa nos preços, serve, também, como hedging de compra para a contraparte. Se os preços se elevarem o comprador do produto estará protegido.
} 
número ótimo de opções de venda e de contratos a termo, mostrando existir sinergia entre esses dois tipos de instrumentos.

\subsection{A Cédula de Produto Rural (CPR)}

\subsubsection{Origens e características}

Como visto no capítulo introdutório, a CPR teve sua origem fortemente influenciada pela crise fiscal iniciada em princípios da década de oitenta, a qual se alastra, a bem dizer, até os dias atuais. Um dos componentes dessa crise foi a redução dos recursos financeiros destinados ao crédito rural, obrigando os agentes privados a buscarem formas alternativas de financiamento de suas atividades.

O Banco do Brasil, idealizador da CPR, dada sua expertise em crédito rural, buscou desenvolver um instrumento que tivesse um status privilegiado do ponto de vista de sua formalização, principalmente constituição de garantias, e que fosse um título com regime de execução privilegiado, visando atrair os agentes financeiros para o seu aval.

Assim é que, na esteira dos contratos a termo e de suas imperfeições, surgiu a Cédula de Produto Rural-CPR. O surgimento desse título teve um verdadeiro caráter de inovação financeira, por permitir o comércio a termo da produção, o desenvolvimento de um mercado secundário, a conjugação com instrumentos de hedging e o alívio da pressão por recursos de financiamento.

O fato de ser um título transacionado no mercado a termo por si só o caracteriza como instrumento de proteção contra risco de baixa de preços. Uma vez emitida a cédula, ocorre a fixação do preço e, o que é fundamental, ocorre a disponibilização do quantum de recursos financeiros ao emissor, caracterizando, assim, um contrato para entrega a termo da mercadoria, porém com acerto financeiro no ato de sua formalização. 
Para Nuevo e Marques (1996, p.626), uma das principais vantagens da CPR, em relação aos instrumentos de financiamento informais como o contrato de soja verde e as operações "troca-troca", reside na diminuição dos custos de transação, ou seja, nos custos de operacionalização e formalização do negócio, das averbações das garantias hipotecárias e pignoratícias e dos custos de fiscalização das lavouras implantadas.

A CPR (Brasil, 1994; Nuevo, 1996) é uma cambial, criada pela lei $n^{\circ} 8.929$, de 22/08/94, através da qual o emitente - produtor rural e suas associações, inclusive cooperativas - vende a termo sua produção agropecuária, recebe o valor da venda no ato da formalização do negócio e se compromete a entregar o produto vendido na quantidade, qualidade e em local e data estipulados no título.

A CPR pode ser emitida para validade entre as partes (vendedor/comprador) ou pode ser garantida por uma instituição financeira. Suas principais características são: ser título líquido e certo, transferível por endosso e exigível pela quantidade e qualidade do produto nele previstos; admitir a vinculação de garantias na forma cedular, livremente ajustadas entre as partes (hipoteca, penhor, alienação fiduciária, aval); não responder os endossantes pela entrega do produto, apenas pela existência da obrigação; responsabilizar o avalista do emitente pela entrega do produto; não admitir que o emitente invoque em seu benefício caso fortuito ou de força maior; constituir-se em ativo financeiro, enquanto vincenda, podendo ser negociada em bolsas de mercadorias ou de futuros ou, ainda, em mercados de balcão; necessitar registro na CETIP, evitando a venda da produção em duplicidade; permitir, quando em cobrança, ação de execução por via preferencial etc.

A Cédula de Produto Rural, portanto, tem duplo papel. Constitui-se em instrumento de financiamento e de garantia de preço, obrigando à entrega física do produto negociado. $\mathrm{O}$ emitente, ao receber o valor correspondente à venda de sua produção no ato da emissão do título pode dispor de recursos para o giro normal de suas atividades. Nesse mesmo momento o preço é travado, gerando vantagens se o preço cair 
na época que seria natural a comercialização do produto, ou seja, como o preço foi fixado ex ante a CPR tornou-se, então, um instrumento de hedging contra oscilações para baixo, aumentando a receita do produtor num cenário de preços desfavoráveis em comparação com aquela que se obteria se não houvesse fixado o preço. No entanto, se o movimento dos preços for ascendente o produtor não poderá se beneficiar do diferencial vigente (preço do mercado versus preço obtido) pois na emissão da CPR já houve a fixação consensual desse valor, estabelecida entre o vendedor e o comprador. Inclusive, nesse momento, o vendedor já terá recebido a parte que lhe cabia pela venda da produção.

No cenário de altas taxas inflacionárias que vigorou por muitos anos no Brasil, a demanda dos produtores rurais sempre foi pela existência de financiamentos em equivalência-produto. A CPR cumpre esse papel. É um financiamento referenciado em produto, possibilitando ao produtor dimensionar seus custos na moeda cujo domínio lhe é estritamente familiar.

Pelas evidências (negócios efetuados), a CPR, como produto ainda novo, para se firmar no mercado e realizar seus objetivos, ainda necessitaria: de um maior desenvolvimento/aprimoramento de mecanismos de proteção (hedging, seguro etc) e de uma mais ampla disseminação/inter-relacionamento com os instrumentos de mercados futuros e de opções. Apesar de nascida como veículo de financiamento, se conseguir os objetivos de interrelação com os demais instrumentos, ajudará a consolidar o mercado de derivativos agropecuários. Observe-se, a propósito, já como resposta do mercado, a tentativa pela BM\&F de lançamento de uma CPR que será objeto de liquidação financeira ${ }^{26}$.

Segundo interpretações correntes, o mercado para absorção de CPR com entrega física seria estreito. Apenas se interessariam pelo produto físico os agentes da cadeia

\footnotetext{
${ }^{26}$ Sobre liquidação financeira ver, por exemplo, Rochelle (1997) e Marques e Mello (1997).
} 
agroindustrial que se localizam a jusante da agricultura. No entanto, tais agentes esbarram na limitação de recursos para financiar o produtor rural.

A alternativa seria atrair para a CPR os detentores de poupança, que buscam opções de investimento. Porém, tais agentes interessam-se tão-somente pela possibilidade de retorno que o título pode proporcionar, não se interessando, em qualquer hipótese, pelo recebimento do produto. Assim sendo, uma alternativa para o financiamento da agricultura seria emissão de um título que, embora representativo de produto rural, não exigisse a entrega/recebimento do mesmo. Essa alternativa poderia ser, então, a CPR com liquidação financeira, idêntica à atual, exceto pela forma de liquidação, baseada em indicador, a exemplo de alguns dos contratos futuros disponíveis.

A CPR pode ser emitida pelo "produtor rural e suas associações, inclusive cooperativas" (Brasil, 1994, Art. $2^{\circ}$ ). Assim, o alcance de seus benefícios vai atingir mais diretamente o segmento produtivo de produtos "in natura", inibindo a realização de negócios com os agentes que se situam a jusante da agricultura, ou seja, os beneficiadores e industriais não pertencentes à categoria de associações ou cooperativas de produtores.

\subsubsection{Utilização pelo mercado}

Para se avaliar a utilização da CPR pelo mercado, duas são as principais fontes de dados: o Banco do Brasil, por ser o principal agente intermediador de operações com $\mathrm{CPR}^{27}$, e a CETIP, por ser o órgão onde os títulos são registrados.

Com relação aos dados do Banco do Brasil, foi possível a obtenção de seus registros desde o início das operações, em 1994, com posição em 15/07/98. Referidos

\footnotetext{
${ }^{27}$ Embora o Banco do Brasil venha se constituindo no principal internediador de CPRs, prestando garantias aos credores através de aval aos títulos, não há qualquer limitação a que outras instituições financeiras atuem nesse segmento negocial.
} 
dados foram disponibilizados por produto (Tabela 3), por safra (Tabela 1) e por unidades da federação.

Tabela 3. Banco do Brasil - CPRs avalizadas, por produto (posição em 15/07/98)

\begin{tabular}{lrrrrr}
\hline Produto & $\begin{array}{r}\text { Quantidade } \\
\text { Física }\end{array}$ & $\begin{array}{r}\text { Unidade } \\
\text { de peso }\end{array}$ & $\begin{array}{r}\text { Quantidade } \\
\text { de CPR }\end{array}$ & $\begin{array}{r}\text { Valor } \\
\text { R } \$ 1,00\end{array}$ \\
\hline algodão & 367.965 & $\mathrm{Kg}$ & 3 & 476.688 \\
arroz & $76 . .032 .000$ & $\mathrm{Kg}$ & 47 & 12.864 .980 \\
boi gordo & 4.599 .135 & $\mathrm{~kg}$ & 32 & 6.456 .932 \\
cacau & 15.000 & $\mathrm{~kg}$ & 1 & 15.000 \\
café & 33.204 .850 & $\mathrm{~kg}$ & 1.678 & 84.943 .595 \\
cana-de-açúcar & 3.763 .508 & $\mathrm{~kg}$ & 2 & 5.000 .000 \\
milho & 9.482 .520 & $\mathrm{~kg}$ & 14 & 785.330 \\
soja & 665.083 .692 & $\mathrm{~kg}$ & 1.224 & 107.476 .595 \\
laranja-suco & 1.333 .800 & 1 & 1 & 1.000 .350 \\
leite & 12.400 .000 & 1 & 36 & 2.650 .000 \\
álcool & 2.959 .000 & 1 & 2 & 1.000 .000 \\
\hline TOTAL & & & & 3.040 & 222.669 .470 \\
\hline
\end{tabular}

Fonte: Banco do Brasil - UEN Rural e Agroindustrial - GECOM/BBCPR

Por outro lado, os dados que se conseguiu obter da CETIP são dados que contemplam o estoque semanal de CPR e não o número de títulos registrados, como seria desejável. Além dessa limitação, os dados não cobrem todo o período de existência do título, permitindo apenas a verificação dos dados compreendidos entre 29/06/96 e 29/12/97.

Pela análise dos dados da CETIP pode-se determinar, para alguns contratos, o número de negócios realizados, enquanto para outros (Tabela 4) apenas se podem fazer inferências. No primeiro grupamento percebe-se a existência de CPRs não contempladas nos dados do Banco do Brasil, como, por exemplo: açúcar cristal, com 331 CPRs; tomate, com 12 negócios, além de trigo e batata-semente, com 1 título cada. Além disso, o número de CPRs de algodão registrado no período citado é de 77 negócios, contra 3 observados nos números do $\mathrm{BB}$. 
Tabela 4. CETIP - Estoque de CPR: contratos mais dinâmicos - 29/02/96 a 29/12/97 (informação semanal $^{2)}$

\begin{tabular}{|c|c|c|c|c|c|c|}
\hline Produto $^{b}$ & $\begin{array}{l}\text { Quantidade } \\
\text { fisica média } \\
\text { (t) }\end{array}$ & $\begin{array}{r}\text { Média } \\
\text { ponderada }^{c}\end{array}$ & $\begin{array}{r}\text { Quant.média } \\
\text { de CPR }\end{array}$ & $\begin{array}{l}N^{0} \text { obser- } \\
\text { vações }^{d}\end{array}$ & $\begin{array}{l}\text { Quant. fisica } \\
\text { em 03/11/97 }\end{array}$ & $\begin{array}{l}\text { Quant. de } \\
\text { CPR em } \\
03 / 11 / 97\end{array}$ \\
\hline cana-açúcar & 7.148 .177 & 7.418 .115 & 76 & 44 & 5.061 .386 & 44 \\
\hline boi gordo & 2.257 & 2.362 & 29 & 75 & 1.370 & 22 \\
\hline café arábica & 4.509 & 9.123 & 153 & 72 & 1.848 & 53 \\
\hline soja & 151.745 & 273.229 & 223 & 84 & 53.743 & 135 \\
\hline
\end{tabular}

Fonte: CETIP

a: 90 observações semanais. Foram utilizadas nos cálculos apenas as observações não repetidas em relação ao estoque de CPR.

b: produtos mais dinâmicos em movimentação de títulos (posição dominante em 29/12/97).

c: quantidade física ponderada pelo estoque de CPR.

d: número de observações por número de estoque não coincidente de $\mathrm{CPR}$.

As CPRs registradas na CETIP e não contempladas nos números do Banco do Brasil, citadas no parágrafo anterior, perfazem 422 negócios e envolvem a quantidade de 531 milhões de toneladas. Em volume de negócios representam apenas 12,8\%, enquanto, em termos fisicos, o percentual é de $67 \%$ daqueles produtos cuja unidade de medida é o quilograma. Deve-se lembrar que os dados daquela Central de Liquidação cobrem um período menor do que os fornecidos pelo Banco do Brasil.

Pelos dados do BB houve apenas $32^{28}$ negócios envolvendo boi gordo. Esse é um segmento de mercado futuro bastante ativo em termos de Brasil. Porém, pelos dados da CETIP relativos a 90 semanas o estoque de CPR de boi gordo situou-se em nível superior a 30 operações durante 44 semanas, tendo, inclusive, alcançado a marca de 40 CPR em estoque na posição semanal de 07/02/97. Isso indica que outros agentes financeiros além do BB estão atuando no aval dessas CPRs, o que é salutar para o desenvolvimento do título como instrumento alternativo de captação de recursos e proteção de preços.

\footnotetext{
${ }^{28}$ Pela informação anterior, posição até 31/12/97, o Banco do Brasil havia intermediado apenas 21 CPR de boi gordo.
} 
Retornando à análise da Tabela 3, percebe-se que o BB já avalizou 3.040 CPR, destacando-se as de soja com 1.224 negócios e as de café, com $1.678^{29}$. Considerada a totalidade de CPRs intermediadas por aquele banco, pode-se inferir que, dentre as razões que levaram à aceitação do instrumento pelos produtores de soja, estariam as seguintes: maiores restrições de acesso ao crédito rural; experiência anterior na realização de contratos de soja verde e melhor nível tecnológico/de informação ostentado pelos produtores da leguminosa.

Com relação ao café, pode-se dizer, também, que a escassez de recursos oficiais de financiamento fizeram com que o produto fosse bem aceito (sempre em comparação com o total de negócios realizados). Contribui para a aceitação da CPR, por parte desse segmento, o fato de o café constituir-se no contrato futuro agropecuário de maior movimentação (Tabela 1), incluindo, até mesmo, a existência de negociações com op̧̧ões.

Embora o volume financeiro global dos negócios com soja supere o valor relativo às operações de café, deve-se registrar que para a safra 97/98 os negócios com soja atingiram R\$11,66 milhões, enquanto o valor para o café totalizou R\$34,02 milhões, registrando um crescimento percentual de $372 \%$. Na safra $98 / 99$, o valor negociado em café atingiu $\mathbf{R} \$ 42,84$ milhões, com crescimento percentual de $25,93 \% \mathrm{em}$ relação à safra anterior.

$\mathrm{Na}$ análise da Tabela 4, percebe-se que os quatro produtos ali indicados são os mais dinâmicos em termos de negociação com CPR. Das 90 semanas que compõem o universo de informações fornecidas pela CETIP, a cana-de-açúcar apresenta movimentação em 44 semanas; o boi gordo em 75; o café arábica em 72 e a soja, líder de movimentação, teve seu estoque alterado em 84 das 90 oportunidades possíveis,

\footnotetext{
${ }^{29}$ Para se ter uma idéia do dinamismo das CPR de café, a posição de 31/12/97 registravá a quantia de 731 CPR de café. A nova posição registrou crescimento de $129,55 \%$.
} 
indicando, pela constância na negociação, estarem ocorrendo negócios que transcendem a obtenção de recursos unicamente para plantio.

Nota-se, ainda, que a média para a cana-de-açúcar foi de 76 negócios, enquanto o estoque de CPR em 29/12/97 era de 44 CPRs. Cotejando esses números com os da Tabela 3, percebe-se que também para esse produto outras instituições financeiras é que estão prestando suporte às transações.

A análise dos dados abertos da CETIP permite visualizar períodos bem específicos de negociação das CPR de soja e café arábica. A Figura 2 permite a verificação desses ciclos.

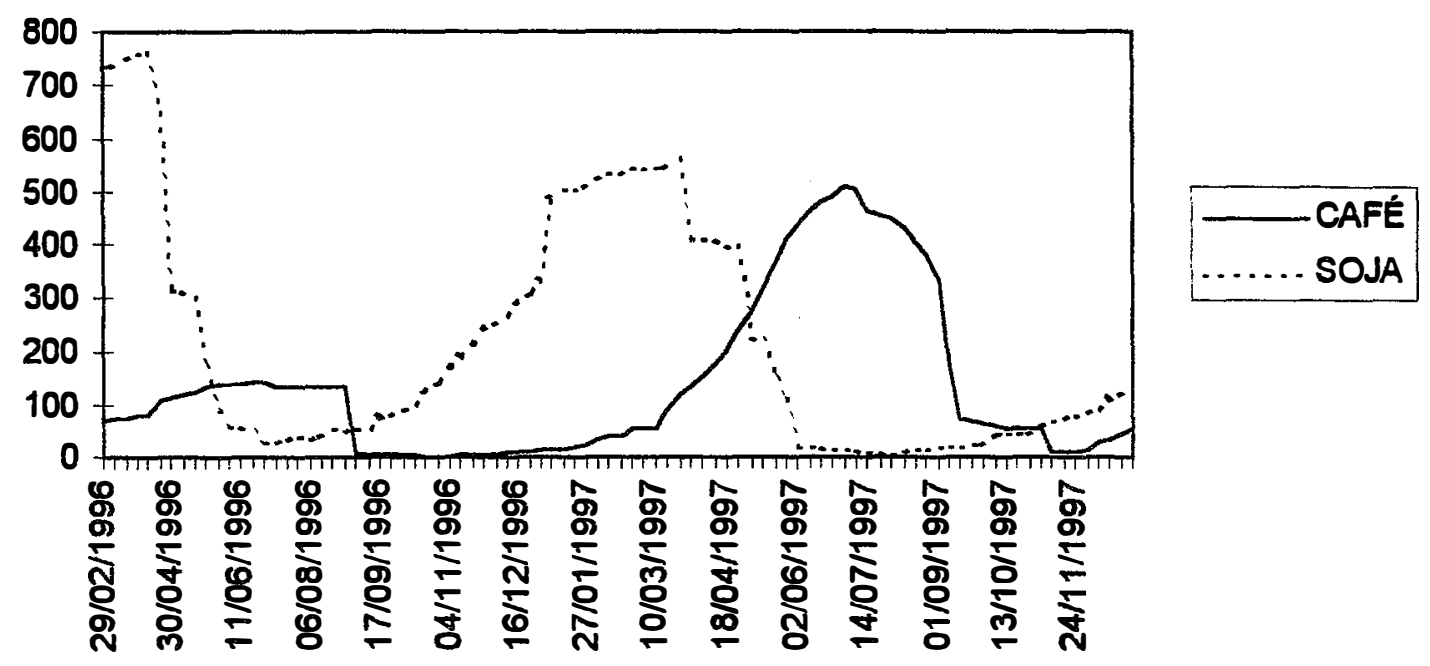

Figura 2 - CETIP - Estoque semanal de CPR de café e soja - 29/02/96 a 29/12/97

Além da deficiência dos dados, há que se registrar que, de acordo com a lei, a exigência de que a CPR seja registrada em "sistema de registro de liquidação financeira" (Brasil, 1994, Art. 19) é válida apenas para os negócios realizados em bolsas e em mercados de balcão. Se a transação se der de forma privada e fechada entre vendedor e 
comprador o registro não se torna necessário e, assim, as informações se perdem, não sendo possível identificá-las. Segundo Machado (1997), principal idealizador da CPR, uma única trading com atuação no país teria realizado cerca de 100.000 CPRs de soja ñ última safra sob a modalidade "fechada", para validade apenas entre as partes vendeç์ora e compradora.

Extrapolando a questão numérica, mas ainda considerando a aceitação do instrumento pelo mercado, Soares (1997, p.c9), expõe que "uma das principais críticas feitas à CPR refere-se às elevadas taxas de juros [taxa de aval], que oscilam atualmente entre $0,45 \%$ e $0,65 \%$ [ao mês], dependendo do prazo para entrega". No entanto, segundo Alcântara, citado por Soares (1997), a perspectiva é de que essas taxas recuem na medida em que novos contratos sejam fechados e de que os riscos com essas operações caiam. A propósito, com o fito de estimular o crescimento do volume de operações com CPR, disseminar o conceito de fidelidade e premiar os produtores adimplentes, foi implantado pelo BB um sistema de bônus sobre a taxa de aval. Esses bônus funcionariam de forma semelhante àqueles existentes para renovação de seguros de automóveis, quando da ausência de sinistro (Banco do Brasil, s/d, "c").

\subsubsection{O desenho dos contratos}

A CPR, por ser um contrato a termo, exibe a característica de ser um título que pode ser feito sob medida, segundo a confluência dos interesses exibidos pelo vendedor e pelo comprador. Além dessa característica de ajustabilidade a cada caso, ela pode ser também transacionada em contratos padronizados. A padronização exibe a vantagem de extrapolar a relação particular vendedor/comprador, com a correspondente necessidade de, a uma dada mercadoria com uma dada qualidade e preço, encontrar um comprador exatamente com esse desejo de compra.

Com a padronização, os mercados podem ser ampliados, fugindo da relação direta vendedor/comprador. Com a característica que a CPR exibe, de agregar uma 
instituição financeira que garanta a entrega do produto, os compradores interessados na mercadoria podem fazer a compra com um alto grau de liberdade: a padronização garante a qualidade do produto a ser recebido e o aval da instituição financeira garante a entrega propriamente dita.

Além disso, a padronização pode expandir os canais de absorção dos títulos, fazendo com que os investidores e/ou tomadores de risco se interessem pelo instrumento e entrem no mercado, aumentando a liquidez e dando vazão à potencial oferta, permitindo ao campo o financiamento privado de suas necessidades e a comercialização antecipada da produção. As CPRs intermediadas pelo BB são todas padronizadas (Banco do Brasil, s/d, "b").

Com a padronização, muitas vezes o volume de produção individual não atende aos requerimentos mínimos para a abertura de um contrato. Uma possível solução seria a negociação em pool, coordenada, por exemplo, por cooperativas. Pela ponta compradora, os bancos/corretoras poderiam montar fundos lastreados em $\mathrm{CPR}^{30}$, ativando, na outra ponta, o segmento de venda antecipada de produto, e a conseqüente formação do funding necessário às operações agrícolas.

Do ponto de vista contratual, pode acontecer com a CPR o mesmo que ocorre com alguns contratos futuros, ou seja, alguns contratos têm êxito, outros não. Dessa forma, quando do lançamento de nova modalidade de CPR seria interessante incorporar aos estudos de viabilidade as condições subjacentes ao sucesso. Parece que o tamanho do mercado físico e seu grau de atomização seriam variáveis importantes.

Além disso, outro item que parece fundamental seria a verificação de se o produto a ser lançado em CPR possui sinalização de preços futuros. Quanto melhor a

\footnotetext{
${ }^{30} \mathrm{Na}$ esteira da criação da CPR com liquidação financeira, a BM\&F intenta, também, a criação de um Fundo de Investimento Financeiro, composto por um mínimo de $51 \%$ de contratos agricolas, para dar sustentação ao crescimento do mercado (Branco, 1997, p. c7).
} 
sinalização, maiores as chances de que as ofertas de compra e venda ajustem um preço que atenda aos interesses recíprocos de vendedores e compradores trazendo, em conseqüência, um deságio mais ajustado às condições vigentes no mercado.

À CPR pode se aplicar, pelo menos em parte, os elementos considerados para o êxito de um contrato futuro. Segundo Working (1970, p.277), quatro condições podem ser listadas para a sobrevivência e prosperidade de um contrato futuro: 1) os termos do contrato e os encargos cobrados devem ser tais que atraiam um número apreciável de operações de compra e venda; 2) deve existir a possibilidade de atração de especuladores em grau suficiente à existência de um mercado fluido; 3) negociadores da commodity devem ter razões para utilização do contrato futuro como substituto temporário para os contratos que irão formalizar mais tarde, no curso de suas atividades; e 4) deve existir um adequado reconhecimento público quanto à utilidade econômica dos mercados futuros.

$\mathrm{Na}$ verdade, certamente o êxito da CPR será maior quanto maior for sua interação com os instrumentos derivativos. Assim, as condições de sucesso para um contrato futuro, guardadas as devidas peculiaridades, podem se aplicar perfeitamente à análise do lançamento de novas CPRs. Além disso, Carlton (1984) ${ }^{31}$, citado por Boteon (1997, p.44), argumenta que a intervenção do governo ou de uma firma na determinação dos preços diminui a probabilidade de sucesso de um novo contrato futuro por, principalmente, diminuir a volatilidade dos preços ou proporcionar vantagens a determinados grupos de agentes. A mesma regra aplicar-se-ia aos contratos de CPR. Quanto mais transparente for o processo de formação e sinalização dos preços, maiores as chances de êxito para o título.

Além dos aspectos discutidos, permanece como importante, transcendendo a questão do aval (que garante ao comprador a integridade do contrato), a credibilidade do

${ }^{31}$ Carlton, D.W. Futures Markets: their purpose, their history, their growth, their sucess and failures. The Jourmal of Futures Markets, v.4, n 3 , p.237-271, 1984. 
instrumento enquanto representativo de produto fisico (quando este for o caso, e não a liquidação financeira). Ou seja, é necessário que os agentes emissores não se sintam tentados a mudar de posição durante a vigência do contrato, acreditando que podem auferir maiores lucros caso o façam. A responsabilidade na emissão do título se traduzirá em taxas nulas ou insignificantes de inadimplência, propiciando, cada vez mais, o fortalecimento desse instrumento financeiro.

\subsubsection{0 processo de formação de preços}

Como decorrência da credibilidade da CPR, os modelos precificadores devem ser aprimorados, fazendo com que o risco de descolamento entre o preço praticado na venda e o observado no mercado disponível seja insignificante. Quanto mais a diferença observada se aproximar dos custos de transporte no tempo, maior será a credibilidade do papel. A esse respeito, inclusive, Kamara (1982, p.262) relata que para vários autores há uma separação entre a decisão de produção e as posições a futuro, indicando que o comportamento ótimo seria aquele que determina a decisão de produção com base somente nos preços dos insumos e nos preços correntes futuros da commodity. Em outras palavras, a decisão de produção deveria se pautar, ao final, pela margem de lucro apurada quando se compara o preço futuro a ser obtido (no caso da CPR transportado para o valor presente) e o respectivo custo de produção ${ }^{32}$.

Nuevo (1996) e Nuevo e Marques (1996) apresentam um modelo para explicar o preço de uma CPR e para balizar a tomada de decisão por parte do vendedor. $\mathrm{O}$ modelo foi desenvolvido para a soja e se baseia, como parâmetro inicial, no preço futuro obtido na Chicago Board of Trade, decomposto para o mercado interno (FOB/Paranaguá). Descontados dos custos operacionais e do custo de oportunidade dos recursos envolvidos, os valores obtidos vão pautar a decisão do produtor e terão que, no mínimo, cobrir seu custo de produção $\left(C_{p}\right)$.

\footnotetext{
${ }^{32}$ Para que o custo de produção expresse de forma mais fiel possível a realidade, dever-se-ia considerar um certo percentual como risco de quebra de safra, pois, havendo quebra, os custos unitários se elevam.
} 
O preço tomado como parâmetro para a negociação da $\mathrm{CPR}\left(\mathrm{P}_{\mathrm{cpr}}\right)$, é baseado no preço futuro $\left(\mathrm{P}_{\mathrm{f}}\right)$ vigente para o produto subjacente no vencimento da CPR. Esse preço pode ser o preço futuro esperado pelo mercado ou pode ser obtido dos valores apurados nas bolsas de futuros. Por exemplo, para a soja normalmente são utilizados os preços vigentes na CBOT, descontado pelos custos de transporte, impostos, corretagens etc., enquanto para o café tem sido utilizado como base o preço futuro formado na BM\&F.

De uma forma geral o $\mathrm{P}_{\mathrm{cpr}}$ deve ser, pelo menos, o preço futuro vigente para o vencimento da CPR $\left(\mathrm{P}_{\mathrm{f}}\right)$, descontado para a data em que a venda do título está sendo realizada, e pode ser representado como na inequação (1).

$$
P_{c p r} \geq \frac{P_{f}}{(1+j)^{n}}
$$

onde, por hipótese, $\quad \mathrm{P}_{\mathrm{cpr}} \geq \mathrm{C}_{\mathrm{p}}$

$\mathrm{Na}$ inequação (1), $j$ é a taxa de desconto mensal do preço futuro $\mathrm{P}_{\mathrm{f}}$, constituída por diversos custos financeiros, expressos em percentagem, como o custo do seguro contra frustração de safra, custo de aval, custo de oportunidade dos recursos, spread do banco etc, enquanto $n$ é o número de meses até o vencimento da CPR. Como visto anteriormente, $C_{p}$ (inequação 2), indica o custo de produção.

É importante lembrar que todos os componentes da taxa de desconto “j”" são negociáveis, dependendo do poder de negociação dos agentes envolvidos na operação. Além disso, as forças de mercado também podem atuar. Quanto maior for a demanda por CPR, tanto menor será a taxa de desconto “j”, melhorando os resultados para o emissor do título. Além do que, "o benefício de um mercado organizado é uma função crescente do número de participantes potencial” (Telser e Higinbotham, 1977, p.997). 
Como previsto em (2) o produtor deve comparar o preço líquido obtenível na venda do produto ao seu custo de produção, de forma a não permitir que sua situação patrimonial seja comprometida se ocorrerem vendas abaixo daquele custo.

Em qualquer fase da atividade ${ }^{33}$, o custo de produção, como visto, deve ser a primeira coisa que um produtor deve apurar antes de tomar sua decisão de comercialização. Esse custo envolve despesas de processamento, armazenagem, transporte, além daquelas de caráter financeiro. Sem um bom conhecimento desses números o produtor não pode calcular seu preço de break-even e, em conseqüência, não consegue avaliar as alternativas que se lhe apresentam (Leuthold et al., 1989, p. 142).

Além dos custos de produção, viu-se acima que o ponto de partida pode ser a utilização de um preço sinalizado pelo mercado futuro da commodity. Para se participar de um mercado de CPR, assim como de um mercado futuro, é crucial o processo de descobrimento do preço (price discovery). Os preços agrícolas são descobertos no mercado através da interação dos movimentos de oferta e demanda, presentes todos os fatores que afetam esses preços.

A existência de um mercado futuro com bastante liquidez constitui-se em uma boa fonte sinalizadora de preços, uma vez que os participantes avaliam as informações disponíveis e as transformam em ofertas de compra e venda, cujo equilíbrio sinalizará para o mercado o patamar de preços que se espera para a commodity sob negociação.

Uma outra alternativa de formação de preços com transparência e razoável grau de ajuste é a existência da possibilidade de os preços serem formados através de leilões, como os leilões eletrônicos do Banco do Brasil que, entre outros produtos, têm ofertado

\footnotetext{
${ }^{33}$ No caso da agricultura, a fase em que se encontra a lavoura vai definir a decisão estratégica. Antes do plantio a avaliação do custo de produção, frente aos preços de mercado, definirá se o plantio oconrerá ou não. Durante o desenvolvimento vegetativo, na pré ou no pós colheita, o custo de producão deverá ser avaliado, até mesmo, com o intuito de se minimizarem perdas decorrentes de situações adversas de mercado.
} 
CPRs. A propósito, Banco do Brasil (s/d, "c") indica que o início de comercialização de CPR via leilão eletrônico propiciou uma melhora substancial dos preços de comercialização das commodities envolvidas, além de aumentar a aceitabilidade do título pelo mercado.

Além dessas, outra alternativa seria calcular o custo de produção, adicionando uma faixa de variação para uma margem de lucros desejada. Com esses parâmetros o produtor submeteria o contrato a um processo de leilão e aguardaria a ação das forças de demanda para testar seu preço e a existência de uma contraparte interessada no negócio.

Ocorre, porém, que na agricultura o elo mais frágil tende a ser o produtor. Assim é que os encargos financeiros embutidos pelos compradores do produto na formação dos preços (deságios praticados em relação ao preço futuro) têm-se constituído em elemento inibidor à formalização de CPRs, estimulando os produtores a realizarem operações de custeio convencional (Banco do Brasil, s/d, "c", p.3).

Dessa forma, a CPR estaria constituindo-se em alternativa apenas quando escasseiam os recursos para financiamento tradicional. No entanto, dados os papéis adicionais que desempenha, de proteção contra risco de preço e de escoadouro da produção, espera-se que o título venha a ser utilizado não só quando os recursos de financiamento se tornam escassos, mas também como alternativa de hedging e de comercialização antecipada.

\subsubsection{A utilização de estratégias combinadas}

Algumas estratégias para utilização de CPR como instrumento de financiamento encontram-se descritas em Nuevo (1996), Frick (1995) e Marques et al. (1997).

Nuevo descreve estratégias voltadas à obtenção de funding, tais como: a) o caso mais simples em que o produtor ou cooperativa emite a CPR com aval de uma 
instituição financeira, diretamente a um exportador, beneficiador ou atacadista; b) um segundo caso onde a CPR é transferida à indústria de insumos ou de máquinas agrícolas, como pagamento por bens adquiridos. A indústria, por sua vez, por não se interessar pelo produto subjacente repassa o título para um investidor ou para um fundo de investimento que, em um dado momento o repassará a um beneficiador ou exportador, devido ao interesse que estes apresentam pelo produto em si; c) um terceiro caso, um pouco mais sofisticado, prevê a emissão de CPRs pelos produtores em favor de suas cooperativas que lhes repassarão recursos financeiros ou bens.

A cooperativa, de posse dessas CPRs, tem duas alternativas: i) emite uma CPR representativa de parte ou do total negociado com seus associados e a repassa, em troca dos pertinentes recursos, a um atacadista, beneficiador ou exportador que tenha interesse pelo produto rural objeto da emissão do título; ou ii) emite uma CPR de parte ou do total negociado com os cooperados e a repassa à indústria de insumos ou de máquinas agrícolas, em troca de mercadorias que serão destinadas ao atendimento dos pleitos de seus sócios. A indústria de posse da CPR cumpre a trajetória indicada em " $\mathrm{b}$ ".

Frick (1995), em trabalho que apresenta a CPR - então um título com cerca de meio ano de existência e com operações apenas experimentais - manifesta a crença de que o título abre interessantes possibilidades de negociação, podendo complementar e até alavancar o crescimento dos mercados de derivativos. Diz ainda, especificamente (p.69), que tanto o emitente quanto o financiador (credor) poderão ter vantagens usando os mercados futuros e de opções, com fins diferentes: o primeiro, para melhorar as condições de financiamento e o segundo para administrar o risco de preço associado à sua posição.

Citado autor, considera que sendo factível incluir alguma cláusula de hedge na CPR, sem desvirtuar sua condição de título líquido e certo, estar-se-ia criando um derivativo de balcão. Seria o caso, por exemplo, de uma CPR com cláusula de recompra em determinadas condições de preço. $\mathrm{Na}$ verdade, um título com essas características 
transformar-se-ia em uma opção de compra para o emitente, criando uma obrigação para uma parte e um direito para a outra, causando uma situação típica de necessidade de administração de risco para o detentor do direito. $O$ agente que assumiu o risco pode transferi-lo na existência de um mercado secundário para esses títulos.

No entanto, além da possibilidade elencada acima, Frick (1995, p.71/7) apresenta alternativas para utilização de CPRs considerando dois subgrupos: estratégias para o credor (comprador) e estratégias para o emitente (vendedor).

No primeiro grupo, considera que o credor, ao negociar uma CPR está alocando recursos para dispor de uma dada commodity no vencimento do título. Assim, os riscos associados à sua posição são devidos à queda de preço do produto, ao aumento da taxa de juros ou à valorização da taxa de câmbio, em produtos de exportação.

Como o alocador de recursos ficará comprado no mercado fisico, o hedging indicado é o de venda, em relação à commodity adquirida. Por outro lado, em defesa quanto à queda da taxa de juros e à queda da taxa de câmbio, deve assumir posição vendida nos respectivos mercados futuros.

Frick descreve uma primeira estratégia, supondo o seguinte cenário: compra de uma CPR, em 16/11/94, relativa a 200 cabeças de boi gordo (18 arrobas cada animal), com vencimento para 17/04/95, ocasião em que espera que cada cabeça de gado esteja valendo US $\$ 500,00$. A expectativa de taxa de juros, em reais, é de $3 \%$ ao mês. Se a taxa de câmbio no dia da transação era de $R \$ 0,83$ por US\$1,00 e sabendo-se que o período continha 100 dias úteis (de 245 no ano), a remuneração, em dólares, do investidor (não considerados os custos de transação) foi de 7,99\% no período, equivalente a $20,73 \%$ ao ano ou $1,58 \%$ ao mês. Até este ponto a operação descrita tem um mero caráter financeiro (definição da remuneração do capital investido) ou financeiro/operacional se o comprador da CPR apresenta interesse no produto subjacente 
ao título. A taxa de 1,58\% ao mês representaria, então, o custo, em dólares, do financiamento obtido pelo emitente da CPR.

No entanto, caso o investidor não quisesse correr riscos, ele poderia realizar as seguintes operações: a) contra risco de queda de preços: venda no mercado futuro de contratos equivalentes aos animais adquiridos, ou seja, contra a venda de 11 contratos futuros de boi gordo na BM\&F, equivalentes a 3.630 arrobas (aproximadamente 200 animais), a US\$27,90 a arroba para o vencimento maio/95. Uma vez que o preço implícito na compra da CPR foi de US\$27,78 por arroba, tem-se uma cobertura adequada do risco. Se em maio a cotação cair para US\$ 26,80 , o ganho de US\$ 1,10 $(27,90-26,80)$ por arroba no mercado futuro compensará o menor preço obtido com a venda dos animais no mercado físico.

O mesmo valor de venda será alcançado se o preço subir, pois não se poderão aproveitar as melhores condições do mercado à vista, devido às perdas incorridas no mercado futuro; b) para fixar a taxa de $3 \%$ ao mês, em reais, supondo que o mercado futuro também trabalha com essa estimativa, bastaria vender dois contratos do vencimento maio/95 por $85.252,86$ pontos e encerrar a posição 15 dias antes do vencimento do contrato futuro; c) como a taxa de juro esperada em moeda nacional era de $3 \%$ ao mês ( $15,92 \%$ no período) e a taxa obtida em dólares foi de $7,99 \%$ no período, isso significa expectativa de uma desvalorização cambial de $7,34 \%$, fazendo com que a relação real/dólar se situasse em 0,89 . Dessa forma, a venda futura de dez contratos de dólar a R\$ 890,00/US\$1.000,00 para o vencimento maio/95 permitiria fixar a taxa de câmbio, administrando o risco de uma valorização cambial e abrindo mão dos benefícios de uma queda na cotação da moeda estrangeira.

Ressalta o autor que o uso das estratégias dependerá das condições de captação e das expectativas sobre o comportamento da taxas de juros e da taxa de câmbio. 
$\mathrm{O}$ credor pode, ainda, quando as condições de preço e liquidez dos mercados o permitirem, usar o mercado de opções para montar posições sintéticas. Resultado semelhante a uma venda a futuro pode ser obtido pela compra de uma opção de venda (put) conjugada com a venda de uma opção de compra (call) de mesmo vencimento e com preço de exercício idêntico. $O$ autor segue enumerando outras estratégias com opções principalmente aquelas que definem uma margem de rentabilidade para a transação (spreads).

Um dos pontos relevantes para um produtor rural quando emite uma CPR é o fato de estar obtendo um financiamento em equivalência produto. Aliás, recursos obtidos dessa forma cumprem um importante papel nas decisões de plantio de um produtor pois a commodity que produz é a moeda sobre a qual o seu domínio é maior. No entanto, quando o recurso é obtido através de CPR, abstraindo a questão do poder para fixação de preço ostentado pelo comprador do título, três são os riscos naturais de que o cródito assim obtido seja um crédito caro: a) quando o preço da commodity aumenta; b) quando a taxa de juros cai; e c) quando a taxa de câmbio sobe (quando se trata de produto de exportação).

Para reduzir o custo associado às hipóteses acima, o emitente poderá se utilizar dos mercados futuros para administrar esses riscos: a) assumindo posição comprada no mercado futuro; b) assumindo posição comprada no mercado futuro de taxa de juros; e c) assumindo posição comprada no mercado de taxas de câmbio.

Pode-se, também, utilizar o mercado de opções para reduzir o custo de captação dos recursos, seja através de posições sintéticas, seja através da aquisição de opções de compra ou seja através da montagem de operações de spread. Enfim, trabalhar essas alternativas constitui-se um vasto campo para o desenvolvimento de trabalhos de engenharia financeira. Um dos principais pontos de que se deve cuidar é a possibilidade de oferecer aos produtores (tomadores potenciais de risco, sempre crentes de que o preço de seu produto vai subir) a possibilidade de auferir ganhos quando da elevação dos 
preços. A possibilidade de aumento futuro de preços e a não definição, a priori, de margens de lucro que o satisfaçam, induz o produtor a ser refratário em relação a instrumentos que lhe fixem o preço, mesmo que esse preço lhe garanta uma razoável lucratividade e uma proteção contra movimentos de baixa.

Já Marques et al. (1997, p.103), ao considerarem estratégias com a Cédula de Produto Rural, descrevem uma operação de compra de CPR de soja com trava simultânea do preço no mercado futuro. Referida operação, em sua estruturação, visa auferir renda de juros superiores às obtidas junto às instituições financeiras em operações normais de seu portfolio, tais como cadernetas de poupança, CDBs e fundos de renda fixa. A operação parte do pressuposto de que um investidor tenha comprado, em 15/05/96, uma CPR de 4.500 sacas de soja, a US\$ 15,00 a saca, despendendo, no total, US\$ $67.500,00$. Nesse mesmo momento, para se proteger contra variações de preço, efetua uma trava na BM\&F vendendo 10 contratos futuros, vencimento setembro/96, a US $\$ 18,70$ a saca:

Sabendo que historicamente a base para Ponta Grossa é de US\$ 0,30 para baixo $^{34}$, o investidor está comprando um produto que poderá vender entre US $\$ 18,70 \mathrm{e}$ US\$ 18,40 , o que poderá resultar em um rendimento entre 5,20 e 5,67\% ao mês, sem risco, porque contará com o aval de um banco. Com a operação no mercado futuro o investidor receberá ajustes da bolsa quando o preço cair e pagará ajustes quando o preço se elevar, neutralizando o resultado em relação ao físico, permanecendo, apenas, o rendimento prefixado pela operação simultânea de compra de CPR e venda de contratos futuros. Esse tipo de operação por fixar o ganho financeiro e por não ter risco de performance, uma vez que conta com aval de um banco ${ }^{35}$, é conhecida como operação de renda fixa.

\footnotetext{
${ }^{34}$ Isto significa que nessa região o preço do mercado fisico situa-se, em média, US\$ 0,30 abaixo do preço futuro da BM\&F.

${ }^{35} \mathrm{Na}$ verdade o fato de ser avalizada por um banco não elimina totalmente o risco da operação, uma vez que também o banco poderá entrar em default, por problemas de insolvência, por exemplo. Todavia, por ser uma operafão de curto prazo, esse risco é mínimo, podendo ser desprezado.
} 
Do ponto de vista teórico várias são as estratégias possíveis, como se pode perceber nos trabalhos citados. No entanto, o primordial é que a CPR seja transformada em um produto rentável. É a possibilidade de lucro que poderá fazer com que haja a emergência e a solidificação de um mercado secundário, e também dos mercados de derivativos, de forma a complementar as possibilidades de ganho e proporcionar estratégias de administração de riscos. É a possibilidade de lucro, em última análise, que vai atrair os investidores (internos e externos) para esses papéis e que vai forçar o mercado a modelar operações que satisfaçam tanto a ponta vendedora quanto a ponta compradora.

\subsubsection{A CPR com liquidação financeira}

A Bolsa de Mercadorias \& Futuros (BM\&F), visando estimular os negócios com papéis agrícolas, preparou um projeto de CPR com liquidação financeira. Com as poucas informações disponíveis, percebe-se que esse título seria praticamente idêntico ao anterior, à exceção da forma de liquidação que, ao invés de constituir uma obrigação de entrega fisica do produto, dar-se-ia por liquidação financeira, baseada em indicador de preços. Na prática, o resgate do título seria feito pela recompra do papel pelo produtor.

Como o título ainda se encontra sob apreciação do Banco Central, não é possível fazer uma análise sobre sua aceitação, incluindo benefícios e eventuais problemas que possa trazer consigo. A principal fundamentação para criação desse título seria torná-lo atrativo para investidores que não desejam ou que, por questões legais, não podem receber o produto. A conseqüência natural (pois presume-se liquidez para o papel) seria propiciar ao produtor uma forma atrativa de obter recursos para suprir suas necessidades de capital na condução de suas lavouras e, até mesmo, em suas necessidades de investimento. 
Os investidores não interessados em produtos agropecuários poderiam participar de um mercado de CPR com liquidação financeira se pelo menos duas condições estivessem presentes: a) possibilidade de obtenção de lucro; e b) certeza quanto ao não recebimento do produto subjacente ao título negociado.

A certeza quanto ao não recebimento do produto estaria representada, por um lado pela existência de um mercado secundário líquido e, por outro, pela própria característica do título. Neste caso seria necessário que a CPR induzisse a liquidação financeira pois, dependendo da situação de mercado, o produtor poderia querer entregar o produto, criando transtornos para o detentor do título que supostamente não desejava ou que não podia receber o produto por imposições legais que atingem sua atividade comercial.

Como qualquer instrumento, a CPR com liquidação financeira apresentaria pontos favoráveis e desfavoráveis, principalmente, dependendo da posição do agente, se vendedor ou comprador.

Como pontos favoráveis podem ser listados: a ampliação do número de compradores, permitindo, pela maior liquidez, a venda tempestiva e em condições mais favoráveis; a eliminação dos problemas de classificação e entrega, tão presentes nas reclamações dos produtores que já fizeram transações através de CPR. Neste caso, os vendedores comercializariam sua produção junto a seus compradores tradicionais e resgatariam a CPR com os recursos obtidos na venda física; redução de custos de preparação e entrega do produto; ampliação do mercado secundário; difusão entre os produtores do hábito de negociar a futuro, podendo incrementar as transações com contratos futuros e com opções; os custos com o registro das CPR poderiam se tornar menores com a criação de formas que substituíssem a necessidade de se recorrer aos registros de imóveis etc. 
Antes de se discorrer sobre os pontos desfavoráveis, deve-se relembrar que os únicos agentes autorizados a efetuar vendas através de CPR são os produtores rurais, suas associações ou cooperativas. Além disso, a lei que criou a CPR prescreve ser ela representativa da promessa de entrega de produtos rurais e, ainda, que o emitente não poderá invocar em seu benefício (em caso de inadimplência) o caso fortuito ou de força maior.

Embora a análise se prenda mais às questões econômicas, parece que o intuito do legislador foi deixar claro a necessidade de que o título estivesse lastreado efetivamente em produto rural: Contrário a esse entendimento, dentre o rol de pontos desfavoráveis podem ocorrer vendas fictícias ou acima da capacidade de produção do emitente. Este fato, caso ocorra, pode ocasionar reflexos na integridade do título ou, ainda, intervenção das autoridades reguladoras.

Outro ponto que pode ser considerado é a vulnerabilidade do produtor quanto a seu produto físico. $O$ produtor normalmente teria que vender seu produto em sua região, sujeitando-se ao poder de mercado de empresas monopsonistas ou oligopsonistas, no que tange a preço e a prazo de pagamento. Além disso, como fragilidade adicional, ao ter que obter dinheiro para resgatar a CPR o produtor pode ficar em uma situação de squeeze. Não é o seu contrato que será recomprado a preços maiores, conforme a definição clássica de squeeze, mas sim, o preço a ser obtido pelo produto será menor, exatamente pela situação de fragilidade que ostentará. Além desses pontos, o comprador do produto pode não honrar a compra, deixando o emitente sem recursos para recomprar a CPR e sem o produto.

De acordo com Hull (1996, p.47), "é a possibilidade de entrega final que leva à determinação do preço futuro". Se esta assertiva puder ser aplicada às CPRs com liquidação financeira, mais um ponto para preocupação poderia emergir pois, nesta modalidade, a entrega física não se concretizaria em qualquer momento. No entanto, este não deve ser um motivo para grande preocupação, uma vez que é prevista a liquidação 
através de indicadores financeiros que, pela sua estreita vinculação aos mercados fisicos, ao fim refletirão a situação desses mercados.

Um outro ponto ainda merece ser considerado. Os indicadores financeiros representam uma média de preços fisicos vigentes em vários mercados. Sendo assim, a aderência do preço de um determinado local, para um produtor individual, vai depender não só da representatividade de seu mercado na formação do indicador, quanto da representatividade e da variação de preços ocorrida nos demais mercados. Ou, em outras palavras, se na CPR o produtor tem o preço formado para o seu produto, através de leilão, no caso da liquidação financeira o preço será referenciado em um indicador, acarretando-lhe o risco de diferencial de preços (diferença entre o preço no mercado local e o indicador), algo como um risco de base.

É reconhecido na literatura que a variabilidade da base é menor do que a variabilidade dos preços. No entanto, na venda da CPR com entrega fisica não há risco de base, enquanto na venda de CPR com liquidação financeira o risco do diferencial de preços estaria presente. Diante desse fato, o produtor deverá se acautelar na hora da venda, levando em consideração, entre outros fatores, a volatilidade de preços de seu produto e a posição de seu mercado no processo de formação da média de preços traduzida pelo indicador. $\mathrm{O}$ que pode ser um bom negócio no ato da venda, pode agregar perdas no ato da recompra da CPR. A título de exemplo, suponha-se que o preço no mercado local, no ato da venda, seja coincidente com o preço espelhado pelo indicador. Se, no momento da recompra, o preço no mercado local for igual ao indicador menos cinco reais, para cada saca, essa será a medida de sua perda.

Enfim, como ainda se trata de um projeto não testado pelo mercado, só uma pesquisa mais ampla poderia apontar chances de êxito ou fracasso e a respectiva extensão dos custos e beneficios para o emitente. Neste momento, o objetivo foi o de colocar alguns pontos para reflexão que podem fomentar a discussão sobre $o$ assunto. 


\subsection{Considerações finais sobre o capítulo}

Neste capítulo foram vistas as condições em que a CPR emergiu; sua conformação dentro da realidade de seu mercado específico - o mercado a termo -, o desenho dos contratos, o processo de formação de preços e algumas das estratégias possíveis para solidificação de seu mercado. Além disso, foi apresentada uma breve discussão sobre a CPR com liquidação financeira.

Alguns pontos podem ser enfatizados. Embora a CPR tenha surgido com o intuito de suprir os produtores de recursos para o plantio/condução das lavouras, sua característica de contrato a termo permite a proteção contra a queda de preços. Além disso, num cenário de preços descendentes, não só a fixação do preço ex ante permite ao produtor auferir uma renda maior como, tendo recebido os recursos no ato da firmatura do contrato, deve-se computar em seu resultado financeiro os rendimentos atribuiveis ao capital antecipado, seja porque fez a aplicação desses recursos, seja porque deixou de tomar empréstimo, eximindo-se, conseqüentemente do pagamento dos juros pertinentes.

O foco deste trabalho está na CPR de café, até agora a que tem se mostrado mais dinâmica. Na primeira safra (95/96), ainda na fase experimental, houve a intermediação pelo Banco do Brasil de 16 cédulas; na segunda esse número se elevou para 142; na terceira 513, enquanto na última safra o número de negócios foi de 1.007, com uma taxa de crescimento de $297,7 \%$ ao ano. Se o crescimento dos negócios continuar, mesmo que em ritmo mais lento, pode-se antever que o nicho para este tipo de negócio se solidificará.

Além de considerações sobre a CPR com liquidação fisica e sobre o mercado a termo, discutiu-se, também, de forma breve, a possibilidade de lançamento da CPR com liquidação financeira e seus reflexos sobre o mercado. Tentou-se levantar e discutir os possíveis pontos favoráveis e desfavoráveis, sem o intuito de esgotar o assunto. Aliás, o aprofundamento da discussão fica como sugestão para outras pesquisas. 


\section{O MERCADO DE DERIVATIVOS}

Walmsley (1988) utiliza uma interessante figura de retórica para ilustrar a sofisticação que os instrumentos financeiros vêm apresentando. Diz o referido autor que durante a infầncia muitos se deparam com a história dos meios de transporte. A essa história compara a evolução dos instrumentos financeiros.

Construindo-se um gráfico dessa evolução (meios de transporte no eixo vertical e o tempo no eixo horizontal), a primeira parte teria inclinação ligeiramente ascendente, compreendendo: o andar a pé, o cavalo, a invenção do bote, a roda, a carroça, a carruagem e o primeiro trem. Depois desses estágios, a inclinação da curva muda acentuadamente com a vinda do automóvel, do primeiro avião, do avião a jato, do supersônico e, finalmente, com as viagens espaciais. A trajetória ascendente é mais impressionante quando comparada às dificuldades existentes nos séculos anteriores.

Com as inovações financeiras algo semelhante sucede. Até o século XIX havia apenas quatro instrumentos transacionados no mercado financeiro: depósitos à vista, letras de câmbio, títulos e ações. Nesse século, aparecem as ações preferenciais e os commercial papers ${ }^{36}$.

A partir de 1966 - ano em que foram criados, no Estados Unidos, os certificados de depósito - inicia-se um movimento bastante rico no lançamento de novos instrumentos financeiros e entidades relacionadas a seu controle/transação,

\footnotetext{
${ }^{36}$ Os commercial papers são títulos de curto prazo para captação de reaursos pelas empresas diretamente do público. No Brasil recebem o nome de notas promissórias.
} 
desembocando na profusão de instrumentos que hoje estão disponíveis no mercado, dos quais os derivativos representam um grande percentual, justificando plenamente a comparação inicial com os meios de transporte.

Walmsley afirma que um importante efeito das inovações financeiras é a dispersão de riscos para todo o sistema. Há dois efeitos possíveis: a) os riscos são transmitidos através do sistema até que são encontrados pontos de ruptura; e b) por conta da transmissão de riscos a movimentação financeira no sistema fica menos sensível a aumentos da taxa de juros.

Um ponto de vista adicional é que as inovações, que permitem a transferência de riscos, têm permitido aos agentes constituir posições muito mais amplas. No passado, quando não se dispunha de tais mecanismos, uma das estratégias utilizadas para se limitar o risco consistia na diminuição das posições em aberto. Interferia-se no tamanho e na qualidade da carteira. Agora as posições são mantidas, de forma protegida, com a utilização de instrumentos derivativos. Dessa forma, os resultados de balanço não sofrem tanta pressão como anteriormente, no caso de insucesso de uma determinada opção de investimento mal feita.

Ainda na visão de Walmsley, as inovações financeiras, ou sejam, os instrumentos derivativos, seriam como a bomba atômica. Elas fazem o sistema financeiro absorver menos riscos, a menos que alguém cometa a loucura de apertar o botão e provocar uma reação em cadeia que leve ao desastre. A propósito, depois que os derivativos tomaram conta das finanças internacionais, praticamente sem controles, uma coordenação dos mercados vem sendo tentada pelos países detentores das economias mais pujantes.

Quando se analisa o desenvolvimento dos instrumentais financeiros, percebe-se que há uma interrelação muito grande desse movimento com a globalização da economia. Cada vez mais aparecem instrumentos que permitem a minimização de riscos e/ou propiciam maior retorno. Percebe-se, também, que nesse mercado o design dos 
produtos busca sempre a adequação às necessidades dos usuários, constituindo-se num mercado onde os produtos têm a tendência de serem feitos sob medida (tailor made).

Com relação aos mercados futuros, CBOT $(1985$, p.12) relata o seu surgimento, dizendo que a contratação de mercadorias a prazo foi praticada em Chicago logo após a fundação da cidade, em 1833, sendo que em 1848 um grupo de 82 pessoas fundou a Chicago Board of Trade. Nessa bolsa eram praticadas tanto as negociações a prazo quanto negociações à vista. Com o agravamento, pela Guerra Civil americana, das condições de oferta e demanda, o desenvolvimento dos contratos futuros foi estimulado.

O relato continua dando conta que, embora a maioria dos registros tenha desaparecido no grande incêndio de Chicago, em 1871, assume-se que os contratos futuros estavam em uso na CBOT desde a década de 1860. Os últimos anos do século XIX presenciaram a formalização das práticas de comercialização, tendo as bolsas estabelecido a padronização de contratos, as normas de conduta e os procedimentos de compensação e liquidação

\subsection{Mercados futuros}

Segundo Taylor ${ }^{37}$, citado por Working (1970, p.270), a comercialização de contratos futuros iniciou-se de forma perfeitamente natural a partir do crescimento na utilização de contratos do tipo "to arrive". Estes, por sua vez, eram os únicos contratos a futuro usados no comércio de grãos antes do estabelecimento do comércio organizado em contratos futuros, na forma como hoje são conhecidos.

Atualmente os mercados futuros agropecuários buscam, basicamente, propiciar a distribuição de risco entre os participantes dos mercados através de mecanismos que

\footnotetext{
${ }^{37}$ Taylor, C.H. "History of the Board of Trade of the City of Chicago". Chicago, 1917, Robert O. Law Co, vol. I, p.193.
} 
possam fixar certas estruturas de receitas, presente a incerteza que medeia a semeadura e a colheita.

No setor rural, onde a decisão de plantio é distanciada no tempo em relação à colheita, a fixação do preço através do mecanismo de negociação futura tem caráter relevante, principalmente se houver ausência de política oficial de garantia de preços (mínimos). Ou seja, tal modalidade disponibiliza ao produtor um instrumento que permite reduzir total ou parcialmente seus riscos de preços, dependendo de sua certeza quanto ao volume a ser colhido.

Admitindo-se que o preço no mercado futuro incorpore as informações disponíveis sobre o preço físico futuro do produto, temos um argumento a sustentar que tais preços são sinalizadores para os agentes que produzem, armazenam e processam referidos produtos. Temos, então, incorporadas, informações determinantes para as decisões de plantar, colher, vender ou processar o produto.

Recuperando um argumento já exposto no capítulo relativo à CPR, vários autores mostram que há uma separação entre a decisão de produção e as posições em futuro. $O$ comportamento ótimo seria aquele que determina a decisão de produção com base somente nos preços futuros da commodity, reagindo a mudanças nos preços futuros esperados somente quando da alteração dos componentes especulativos da posição em futuros (Kamara, 1982, p.262).

Para alguns autores, os mercados futuros existem porque permitem a transferência de risco, eliminando os componentes de super oferta, nível de estoques reguladores, preços de bens substitutos, mudanças de hábitos de consumo etc (Camargo, 1991). Essa série de variáveis - que interferem na fixação do preço do produto agropecuário - e a distância no tempo entre o plantio e a colheita são determinantes na fixação do preço. 
Os contratos futuros se desenvolveram e se sofisticaram de tal forma que, deixando a idéia inicial de representarem "produtos", hoje são vistos como um instrumento financeiro, tratando-se de uma troca de compromisso monetário por compromisso em mercadoria, de tal forma que aos especuladores cabem as obrigações financeiras e aos hedgers as obrigações que dizem respeito ao manuseio da mercadoria (Souza, 1994, p.19).

$\mathrm{Na}$ verdade, embora a atividade de hedging esteja ligada, em sua origem, à busca de proteção contra variações de preços de um determinado ativo, hoje ela extrapola esse objetivo e se insere muito mais como uma atividade de gerenciamento de carteira de investimentos, onde normalmente é buscada a maximização do lucro conjugada com um risco o mais baixo possível, ponderadas as condições e oportunidades que o mercado apresenta. Como decorrência, uma operação de hedging reduz a variância do retorno esperado do portfolio. Ao reduzir as possibilidades de grandes perdas, reduz, também, a chance de grandes ganhos (Bessada, 1995, p.56), ou, nas palavras de Hull (1996, p.108), o hedging tende a melhorar resultados desfavoráveis e a piorar resultados favoráveis. Em conseqüência, a proteção ideal vai depender da preferência, habilidade e sensibilidade do administrador do portfolio.

Note-se, aqui, a semelhança com a CPR. Embora esse título tenha se originado como um mecanismo de financiamento serve, também, como proteção contra queda de preços. No entanto, para maior efetividade, seria oportuna a conjugação com mecanismos que permitissem ao emitente a apropriação pelo menos de parte da variação positiva de preços acaso ocomida.

De acordo com Working (1962), um hedging é feito por muitas razões, as quais variam de acordo com as circunstâncias. Propõe uma classificação que considera cinco motivações diferentes para sua caracterização, de acordo com os objetivos do negócio do hedger e com os efeitos econômicos. 
A primeira das motivações, classificada como hedging de custo de carregamento, considera que a transação é feita com o objetivo de lucrar com o armazenamento de uma dada mercadoria. Este tipo de operação é feita normalmente por armazenadores que possuem capacidade ociosa. Consiste na aquisição de uma mercadoria e a simultânea venda de contratos futuros. $\mathrm{O}$ armazenador busca $\mathrm{o}$ lucro derivado de variações nas relações entre os preços disponível e futuro (base ${ }^{38}$ ), ao invés de assumir risco de variação nos níveis de preço ${ }^{39}$. A decisão que ele toma se refere não à questão de se ele faz a proteção ou não, mas sim, se ele armazena ou não.

A segunda das motivações, $o$ hedging operacional, tem $o$ intuito de facilitar as operações de comercialização ou processamento de produtos. Os benefícios dependem da existência de alta correlação entre variações no preço spot e nos preços futuros em intervalos curtos - de um dia para o outro, ou dentro do mesmo dia. O hedging operacional é um substituto temporário para uma transação de compra ou venda de uma commodity. $\mathrm{O}$ contrato futuro é mantido até que a transação no fisico seja efetivada.

Em terceiro lugar é considerado o hedging seletivo, o qual consiste em buscar proteção para os estoques, de acordo com as expectativas de preços. A proteção deve ser inferior ou superior aos estoques dependendo das circunstâncias. É parte hedging e parte especulação. $O$ objetivo consistiria na prevenção de grandes perdas sobre os estoques, enquanto se preserva a oportunidade de lucros especulativos no disponível.

Como quarta motivação, Working considera $o$ hedging de previsão (anticipatory hedging), guiado por expectativa de preços. É usado por produtores ou processadores como um substituto para um contrato de compra ou venda da mercadoria disponível. $\mathbf{O}$ propósito é obter vantagens com o preço futuro corrente. Pode assumir tanto a posição

\footnotetext{
${ }^{38}$ Diferença entre o preço do produto no mercado disponível e o preço futuro.

${ }^{39}$ Para Working (1962, p.438), os comerciantes cujos negócios requerem atenção quanto às diferenças de preços relativas à classificação do produto, qualidade e localização estão melhor aparelhados para obter lucro de armazenamento pela previsão de variações da base. Por isso a conclusão não se dá em relação a fazer o hedging ou não, e sim, se ammazena ou não o produto.
} 
comprada quanto a vendida, ou seja: a) compra de contratos futuros por processadores, como forma de cobrir necessidades de matéria-prima; b) venda de contratos futuros por produtores, antes que o ciclo de produção se complete. No primeiro caso, serve como substituto imediato para a matéria-prima, enquanto no segundo, serve como substituto para a commodity que ainda está em fase de produção.

Por último, a quinta das motivações diz respeito ao hedging para evitar risco, utilizado para fazer a proteção dos estoques. Essa operação é normalmente do tipo vendido (short). É feita com o objetivo de proteger contra flutuações adversas nos preços e normalmente se refere à totalidade dos estoques. Working considera este tipo de hedging não importante ou virtualmente inexistente nas práticas negociais modernas Teria sido importante nos primórdios dos mercados futuros.

\subsubsection{Participação no mercado}

Embora a Bolsa de Mercadorias \& Futuros (BM\&F), por exemplo, conte com programas que buscam a alavancagem dos contratos futuros agrícolas, fazendo com que os mesmos se tornem uma realidade de mercado e não simplesmente existam de direito, e que nesses programas a sensibilização do produtor seja buscada, a realidade é que a participação de produtores nos negócios totais da bolsa é extremamente baixa. Isso é de se esperar porque mesmo nos países mais desenvolvidos a participação de produtores ainda é pequena.

Martines Filho (1996, p.2), citando trabalho de Smith, encontrou os seguintes números para os Estados Unidos: $12 \%$ dos produtores de milho e soja utilizavam o mercado futuro como instrumento de apoio à comercialização de suas safras, enquanto para o segmento de opções esse número era de $6 \%$. No entanto, $46 \%$ utilizavam contratos a termo como instrumento de comercialização de suas safras. E, ainda, com relação à mesma pesquisa, a definição de que, no rol de produtores que negociavam 
commodities em mercados futuros, o perfil era, em sua maioria, o de produtores jovens, com maior nível de escolaridade e com volumes de venda mais altos.

Ainda com relação à participação nesses mercados, Bahn $(1996$, p. 1) - citando pesquisa realizada, em 1992, por Schroeder e Goodwin ${ }^{40}$ no Estado do Kansas - registra que embora o uso de contratos a termo, futuros e opções tenha crescido nos 10 anos anteriores à pesquisa, $98 \%$ dos produtores rurais ainda vendiam a maior parte de sua produção nos mercados à vista. Aqueles que se utilizavam dos mercados a termo, futuros ou opções, o faziam para cerca de um terço de sua produção.

Adicionalmente à participação de produtores rurais nos mercados futuros - se se pensar exclusivamente na tomada de posições em contrapartida àquelas detidas no físico, e não como estratégia complementar às operações de CPR, por exemplo -, para que um produtor rural participe desse mercado ele deve se sentir compelido a fazê-lo. Ele vai tomar posição se entender que essa ação pode servir de instrumento auxiliar em sua estratégia de comercialização. Para tanto, seriam necessários modelos preditores de preços, com bom nível de sinalização, e que levassem em consideração todos os custos incorridos na entrada e na saída do contrato.

Caso se quisessem esses modelos mais bem elaborados, deveriam ser incluídos os custos das margens e dos ajustes diários. A decisão do produtor não pode se pautar em ganhos ou em proteção hipotéticos. A decisão deve levar em conta possibilidades concretas de ganho ou proteção, sopesados os custos incorridos ao assumir determinada posição.

A utilização do modelo buscaria a definição de um patamar de preços que viabilizasse a participação do produtor e fizesse com que o mesmo sentisse uma certa segurança quanto ao resultado que alcançaria (minimização de risco devido a ameaças

\footnotetext{
${ }^{40}$ Schroeder, T.C. \& Goodwin, B.K. Marketing Practices and Seminar Participation of Kansas Agricultural Producers. Kansas Agr.Exp.Sta. Report of Progress 692. Manhattan, KS. Kansas State University, 1993.
} 
consistentes de queda de preços ou possibilidade de aumento de lucros na tomada de posições no mercado, conjugadas com suas posições no físico). Além disso, a questão cultural certamente desempenha um importante papel.

Talvez como forma de aumentar a participação no mercado, uma simplificação pudesse ser buscada. Ao invés de participações individuais, não seria possível a negociação em pool, formando-se uma carteira gerenciada por associações, cooperativas ou, até mesmo, por corretoras? A resposta dever ser buscada principalmente pelos agentes que apresentam interesse no alargamento da base de atuação dos players desse mercado.

Com as dificuldades que se têm vislumbrado quanto à participação de produtores rurais nos mercados futuros agropecuários, a utilização desse mercado - abstraindo-se o papel dos especuladores e dos arbitradores - se dá mais na ponta compradora/ intermediadora dos produtos agropecuários. Muitos dos participantes, principalmente aqueles de menor porte se sentiriam compelidos a, participando, extrair vantagens da formação de preços derivada da participação de bem-informados negociadores de commodities (Working, 1970, p.294).

No entanto, sempre que se buscar a participação em um contrato futuro deve-se levar em conta que se a prática de hedging não for norma para um determinado segmento, não haverá sentido em que um agente escolha ser diferente dos demais (Hull, 1996, p.92).

\subsubsection{Função econômica}

Existe bastante controvérsia na literatura acerca das funções econômicas dos mercados futuros. Williams (1986), por exemplo, com uma argumentação bastante enfática considera que os mercados futuros não devem ser vistos como seguro nem, tampouco, como sinalizador de preços, uma vez que não são só esses mercados que 
contêm e transmitem informações sobre o futuro. Além disso, a teoria da liquidez também não se aplicaria entre os contratos futuros e os contratos a termo.

A visão de que a presença de risco na produção agrícola, no transporte e no processamento seria a grande motivadora para a contratação de hedging não se sustentaria, uma vez que não são só os contratos futuros que previnem riscos. A diversificação da produção, a ação em pool, a negociação a termo, entre outras iniciativas, também podem eliminar riscos.

Para esse autor, então, o primeiro propósito dos mercados futuros seria o de servir como um mercado de empréstimo implícito de mercadorias (implicit loan market). Williams diz que a teoria do mercado de empréstimos implícitos é uma extensão da teoria de oferta de estocagem de Working ${ }^{41}$ e teria por princípio explicar porque as firmas mantêm estoques com perdas aparentes, além de tornar mais claro que os dealers usam os contratos futuros como parte de um conjunto mais complexo de transações através do qual eles tomam commodities emprestadas.

O ponto central é a simultaneidade das operações, ou seja, a firma não adquire seus estoques no mercado físico para então, após contemplar o risco de sua posição, fazer o hedging com uma venda a futuro. Antes disso, as firmas concebem e executam as duas operações - aquisição no fisico e hedging em futuros - como se fossem uma única operação, comparando com a prática generalizada de operar a base, na qual os traders discutem somente a diferença entre o preço spot e o preço futuro.

A análise não considera que o grau de aversão ao risco esteja correlacionado com o desejo de assumir posições no mercado futuro. Decididamente, este não é o modus operandi dos hedgers. Na verdade, a razão pela qual os mercados futuros existiriam

\footnotetext{
${ }^{41}$ A teoria da oferta de estocagem de Working explicaria porque os dealers ofertm serviços de armazenagem muitas vezes com perdas aparentes (spreads menores do que os custos de carregamento). Eles estariam considerando o convenience yield e assim planejariam o preço de armazenagem (spread entre os preços spot e futuro apropriados).
} 
deriva das razões pelas quais os dealers mantêm estoques ${ }^{42}$, porque, uma vez que há riscos envolvidos não significa, necessariamente, que a aversão ao risco seja dominante na explicação das reações das firmas frente ao risco.

Enquanto a teoria de Williams prediz que as commodities com maiores inflexibilidades relativamente à produção, transporte e processamento apresentam uma condição mais provável de desenvolver um ativo mercado futuro, a corrente que enxerga os mercados futuros como seguro contra risco de preços estabelece que isso vai ocorrer para as commodities que apresentam preços mais voláteis.

E o autor conclui de forma bastante contundente

"a evidência suporta uma e somente uma teoria. A função dos mercados futuros é servir como um mercado de empréstimo implícito para commodities. Um mercado de empréstimos, seja para dinheiro ou commodities, aloca 'estoques' escassos para as firmas cuja necessidade por eles é a maior no momento. A partir da barafunda gerada pela negociação de contratos futuros [no pit de negociações], os preços emergem com notável ordem e sofisticada condição alocativa para a taxa de juros nos empréstimos das commodities" (Williams, 1986, p.236).

A visão exposta por Williams desloca a questão da proteção/transferência de risco $^{43}$ do centro das funções econômicas dos mercados futuros e coloca em seu lugar a possibilidade de o mercado funcionar como um "centro" de empréstimo temporário de commodities. Mais ou menos na mesma linha Frick (1996b, p.36), coloca como uma das mais importantes funções dos mercados futuros a possibilidade de regulação do volume

42 Uma das razões que levariam os dealers a manter estoques é a possibilidade de ganhos de convenience yield (ganhos gerados pela manutenção da mercadoria devido à sua escassez temporária ou pela possibilidade de manter o processo de produção em andamento).

${ }^{43}$ Telser (1981), lista uma série de argumentos contestando a teoria do seguro de preços. Enfatiza que não é a demanda por proteção que explica porque há um organizado mercado futuro e sim, a demanda por um instrumento financeiro fungível, comercializado em um mercado liquido que tome necessária a criação de tal mercado. Sua principal explicação para a existência de mercados futuros organizados é que eles facilitam as transações entre estranhos. Em uma comparąão com o mercado a termo o autor diz que o contrato futuro está para o contrato a terno, assim como o dinheiro em espécie está para o cheque nas transações comerciais. No primeiro caso a identidade/idoneidade dos agentes não é relevante, enquanto no segundo é fundamental. 
de estoques da commodity física, permitindo aos produtores evitar a venda nos períodos de oferta abundante e adiá-la a seu critério.

Já para Working (1970, p.286) os mercados futuros oferecem a oportunidade para comprar ou vender a qualquer tempo e com o máximo de conveniência. Assim, um contrato futuro pode ser substituído por uma operação no físico tão logo a oportunidade para tal se ofereça. Por uma questão de especificação de qualidade, ou da existência de contrapartes, muitas vezes o contrato futuro pode ser usado como um substituto para a operação que seria realizada no mercado físico.

Com essa visão Working caracteriza as formas pelas quais os contratos futuros podem ser utilizados como substitutos temporários para operações no mercado físico: a) meramente por conveniência, permitindo que a pertinente operação no físico seja feita logo após, porém ditada pela conveniência e não por pressão; b) porque o preço no mercado futuro é mais favorável que qualquer preço imediatamente disponível no mercado a termo (qualidade e localização considerados); e c) por virtual necessidade, porque o mercado futuro oferece a única oportunidade prática para fazer uma venda ou compra para se concretizar no futuro, no tempo desejado.

Estas razões para se escolher transacionar ou não nos mercados futuros é que vão emoldurar os beneficios que se pode ter operando em tal segmento. Derivadas desses beneficios emergem, então, as funções econômicas dos mercados futuros na visão de Working (1970, p.294/7), as quais são constituídas, por: a) efeitos sobre a variação de preços; b) utilidade para os detentores (handlers) de commodities; e c) precificação competitiva.

A primeira das razões diz respeito ao fato de existir maior ou menor variação de preços na presença de um mercado futuro para uma dada mercadoria. Para Working, isto não pode ser demonstrado apenas com base em argumento econômico, sendo que as evidências estatísticas apontam em uma direção: a variação média sazonal nos preços 
tende a ser menor na presença de um mercado futuro do que em sua ausência. Além disso, operações em mercados futuros indicariam uma tendência à moderação de flutuações de preços, através da diminuição da amplitude de variação causada por mudança nas perspectivas de oferta.

Os mercados futuros oferecem uma rica recompensa para a identificação bastante antecipada de alterações na oferta da commodity negociada. Se, por exemplo, uma escassez é identificada, nessas condições o preço para equilibrar o mercado é menor do que aquele que seria necessário se o evento fosse identificado em prazo mais longo.

Com relação à utilidade para os detentores de commodities, os mercados futuros só existem se puderem destinar algum benefício a esses agentes. Os beneficios obtidos por produtores, comerciantes, armazenadores e processadores diferem de acordo com a natureza específica do negócio e outras circunstâncias. Um beneficio que ocorre freqüentemente é a redução de risco junto com a capacidade de se evitar a necessidade de tentar antecipar as prováveis mudanças nos preços.

Pode-se considerar um exemplo: um envasador de frutas deve possuir açúcar quando as frutas chegarem para embalagem. Do ponto de vista econômico, porém, é contraproducente acumular grande estoque de açúcar. No entanto, através da utilização dos mercados futuros ele pode, com efeito, comprar o açúcar necessário de forma bastante antecipada, quando o preço for considerado vantajoso, sem ter que arcar com os custos de estocagem.

Tais usos dos mercados futuros não são vantajosos somente para um agente com bom julgamento de preço; eles tendem também a promover um melhor ajustamento do preço às condições existentes de oferta e/ou das perspectivas sobre o que irá ocorrer se os detentores de commodities tiverem uma capacidade de julgamento mais restrita em relação à identificação dos preços que irão vigorar. 
Finalmente, no que Working $(1970$, p.296) denomina de precificação competitiva, tem-se que na presença de mercados futuros, com seu processo de negociação aberto e competitivo, a ausência de um mercado físico nessas mesmas condições não importa. Os preços nos mercados futuros mostram, de forma acurada, o balanço corrente da opinião de mercado, ou seja, ajudam a posição negocial dos produtores, pequenos comerciantes e pequenos processadores ainda mais do que num mercado físico aberto e competitivo, que registrasse somente preços em transações spot.

Segundo Working, o fato de os mercados futuros estabelecerem negociações abertas e competitivas, sinalizando preços, constitui-se em seu principal mérito, do ponto de vista do bem-estar social.

À parte os entendimentos de Williams aqui discutidos, Johnson (1960) propõe uma reformulação da Teoria de Hedging, admitindo formalmente a possibilidade de o hedger aderir ao mercado com o intuito de proteção, definindo, contudo, uma situação ótima em que pode fazê-lo. Vai mais além, dizendo que não há distinção entre o hedger e o especulador "ordinário", na medida em que ambos são motivados pelo desejo de obter a combinação ótima de retorno e risco esperados, conforme determinados por suas respectivas funções de utilidade.

Kamara (1982, p.288), por sua vez, considera que os dois papéis mais importantes desempenhados pelos mercados futuros são a possibilidade de hedging e o caráter de informação neles contidos. Estes dois papéis permitem a estabilização dos mercados disponíveis e a melhoria da alocação intertemporal de recursos.

\subsubsection{Participantes do mercado}

Marques e Mello (1996), dentre outros autores, atribuem o conceito de hedger aos agentes econômicos que se relacionam com a mercadoria física, sejam vendedores ou compradores e que buscam um seguro contra variações de preço. Aqueles que detêm 
posições no mercado disponível participam em futuros vendendo contratos (short), enquanto aqueles que necessitam do produto fisico, entram no mercado comprando contratos futuros (long).

No entanto, desde o trabalho de Working (1953) vêm sendo expostas análises que consideram que a adesão aos mercados futuros por parte dos hedgers não se limita à questão de buscar proteção contra movimentos desfavoráveis dos preços, mas, também, o aumento de lucratividade derivada das posições assumidas.

Nessa linha, Kamara (1982, p.263) expõe que a posição futura dos hedgers é motivada parcialmente pelo desejo de estabilizar a renda e parcialmente pelo desejo de incrementar os lucros esperados, tal que a posição futura passa a ser uma mistura de hedging e especulação. Consequientemente, hedging e especulação não são opostas uma à outra, mas, sim, atividades similares com preços diferentes servindo como base de especulação. Os hedgers, nessa visão, especulam tanto na base (mais nesta) quanto no nível de preços, enquanto os especuladores especulam somente no nível de preços.

No entendimento de Marques e Mello (1996), assim como no de vários outros autores, existe um agente de fundamental importância estratégica para a liquidez dos negócios que é o especulador. Esse agente está interessado em auferir ganhos com a compra e a venda de contratos, não se interessando diretamente pelas mercadorias envolvidas. Sua grande participação consiste na equalização da oferta e demanda pois nem sempre o número de hedgers é suficiente para fechar a contento os interesses daqueles que ofertam contratos para venda com o desejo de compra pelas contrapartes.

Apesar de, em princípio, haver uma clara distinção entre hedgers e especuladores, na prática essa distinção não é muito clara. Alguns autores consideram que tanto os hedgers quanto os especuladores entram no mercado para conseguir lucros e, assim procedendo, ambos assumem riscos, resultando, em última análise, em especulação. 
Forbes $\left(1994\right.$, p.33) cita Hieronymus ${ }^{44}$ para conceituar hedging.

\begin{abstract}
'Diz-se, muitas vezes, que hedge é o contrário de especulação. Isso não é verdade: tratam-se, apenas, de dois aspectos da mesma coisa. $O$ que usualmente se define como especulação - posições compradas ou vendidas - é especulação nas alterações dos níveis de preços. Por outro lado, o que se identifica como hedge - isto é posições compradas no físico e vendidas no futuro, ou vice-versa - é especulação nas relações entre os preços. Hedge e especulação não são opostos. Ao contrário, são conceitualmente similares, constituindo-se tãosomente, em espécies diferentes de especulação".
\end{abstract}

Operadores do mercado entendem que para o produtor rural, tomar risco seja um processo natural, pois ele sempre está esperando que o preço de seu produto se eleve, muitas vezes sofrendo sérios reveses no processo de comercialização de suas safras. No entanto, o produtor nunca vai se admitir como um especulador. Para ele, operar em mercados futuros se identificaria muito mais com especulação do que a preservação de arriscadas posições no físico.

Para que o produtor pudesse utilizar o mercado de papéis - futuros e opções - no auxílio de suas estratégias de comercialização, um forte trabalho de esclarecimento e mudança cultural mereceria ser empreendido. Além disso, o afastamento do Governo paternalista, principalmente para as culturas de maior cunho empresarial, deveria ser considerado. Aliás, a CPR pode ajudar em muito a assimilação dessas estratégias. Ao se constituir em venda antecipada, reforça o papel de hedging, ao mesmo tempo em que incorpora "noções" de comercialização tradicional, ao representar a obrigatoriedade de entrega da mercadoria (operação no físico).

Assim, se o hedging é administração de risco, no sentido de se buscar proteção contra variações de preço, então entende-se perfeitamente o aparecimento da figura do hedger, cuja função primordial seria buscar segurança para suas posições. No caso de

\footnotetext{
${ }^{44}$ Hieronymus, Thomas A. 'Economics of Futures Trading". Washington, 1971.
} 
um produtor rural, por exemplo, ele já corre vários riscos em sua atividade de produzir. Para que não se torne um especulador em potencial (no físico) deve, então, buscar proteção em um mercado organizado que permita a minimização de seu risco de preço.

Enquanto o papel do hedger parece claro, que dizer do especulador? Dois parecem ser os motivos principais para o seu surgimento: a) realizar lucros com a compra/venda de contratos a partir de variações nos preços, as quais tenta antecipar; e b) aproveitar-se do grau de alavancagem exibido pelos mercados futuros (Hull, 1996). Neste caso, além de as margens de garantia exigidas serem relativamente pequenas frente ao valor dos ativos-objeto, podem ser honradas com títulos ou fiança bancária.

A partir dessas duas motivações econômicas, o especulador vai, então, assumir riscos e auxiliar sobremaneira na formação da liquidez do mercado. Sem esta presença, os hedgers teriam um estreitamento de possibilidade de realização de negócios, reduzindo-se, assim, suas possibilidades de transferência/compartilhamento de riscos.

Uma maneira de se constatar o importante papel desempenhado pelo especulador pode ser verificada, por exemplo, nas condições que favorecem o fracasso de um determinado contrato e que foram expostas por Working (1970, p.283). Dentre as possibilidades listadas encontra-se a incapacidade de o contrato atrair especulação em nível suficiente para dar a liquidez necessária que garanta um alto grau de utilização do contrato para hedging.

Vê-se, portanto, que os especuladores são importantes participantes do mercado. São aqueles que propiciam a condição para que um determinado contrato se estabeleça de forma exitosa.

Um terceiro agente, sobre o qual ainda nada foi dito, é o do arbitrador. Este tem um papel parecido com o do especulador, na medida em que também contribui para o 
aumento da liquidez do mercado. Além disso, desempenha um importante papel que é o de corrigir eventuais distorções de preços.

Os arbitradores travam um lucro sem risco, realizando operações simultâneas em dois ou mais mercados. Sempre que existir alguma distorção no preço de determinado ativo, abre-se a possibilidade de arbitragens, que são operações que visam obter um ganho com essas distorções. Assim, descontado os custos de transporte, se um produto está mais barato no mercado $\mathrm{X}$ do que em $\mathrm{Y}, \mathrm{o}$ arbitrador irá efetuar a compra em $\mathrm{X}$ para vendê-lo em Y.

No entanto, a ação desses agentes vai fazer com que o preço aumente no mercado onde é baixo e diminua onde é mais alto. A interação das forças de oferta e demanda vai fazer com que os mercados se equilibrem. Dessa forma, a arbitragem tem como conseqüência o ajuste de um preço distorcido ou fora do real de uma mercadoria ou de um outro ativo qualquer. $O$ resultado advindo da arbitragem é uma maior eficiência do mercado na sinalização dos preços futuros.

Embora o papel do arbitrador e do especulador guardem certa semelhança, não se deve confundir esses dois agentes. A arbitragem é uma operação de troca, onde o ganho é realizado por diferenças (spread); a especulação é uma operação aberta ao risco, onde o agente assume uma única ponta, compra ou venda, podendo até estar comprado em um mês e vendido em outro mês de vencimento.

\subsubsection{Variações de preço/base}

Como já visto nos tópicos anteriores, uma operação de hedging está ligada, tanto quanto possível, à neutralização do risco de uma variação desfavorável de preços. Tais operações tendem a melhorar resultados desfavoráveis e a piorar resultados favoráveis. A razão intrínseca relaciona-se ao fato de estar presente o risco de base. 
A base é definida como a diferença entre o preço à vista do ativo sobre o qual se quer tomar posição e o preço futuro do ativo utilizado para o hedging. Para um mesmo ativo, a tendência é que ocorra a convergência entre os dois preços. Se essa convergência culminar com a nulidade da base no vencimento do contrato, o risco de base deixa de existir e o processo resulta no chamado hedging perfeito.

No entanto, os preços à vista e futuro podem variar de uma forma que aumente ou diminua o risco da proteção buscada e, conseqüentemente, os resultados sejam afetados. Se o preço à vista cresce mais do que o preço futuro a base aumenta. Este fenômeno é conhecido como fortalecimento da base. Ao contrário, quando o preço futuro cresce mais do que o preço à vista, a base diminui, o que é chamado de enfraquecimento da base. $\mathrm{O}$ risco do hedging está, portanto, associado à variação da base, ou seja, é a incerteza associada à base.

Consideradas as variações da base, o hedging consiste, então, em se trocar uma posição em que é alto o risco de se ficar comprado ou vendido, por uma cujo risco é mais aceitável e gerenciável, envolvendo apenas a variação da diferença de preços entre o mercado fisico e o futuro. $O$ conhecimento das variações da base é essencial para que ocorra a decisão de se iniciar uma operação de hedging ou para fazê-la cessar, pois, monitorando-se a base, percebe-se quando o mercado está favorável ou não às posições que se quer assumir ou já assumidas.

Há um consenso na literatura de que a base é menos volátil e mais previsível do que as variações dos preços spot e futuro. Dessa forma, segundo Correa (1995, p.43), um hedger não estaria preocupado com o nível absoluto dos preços, nem mesmo com a tendência do mercado, mas com os movimentos relativos dos preços ou, mais especificamente, com o fortalecimento ou enfraquecimento da base.

Inerente à questão da base, Working (1953a, p.320/1) já advertia que a maior fonte de erros nas noções de hedging é a prática convencional de ilustrar uma operação 
com um exemplo hipotético, no qual o preço futuro é suposto aumentar ou declinar pela mesma quantidade observada nos aumentos ou quedas do preço do ativo no disponível. Complementa a idéia, com a observação de que desde que os preços spot e os preços futuros não se movem completamente em paralelo, os hedgers arbitram os dois mercados e, quando capazes de predizer as flutuações da base, eles lucram.

Para Kamara (1982, p. 264/5), a base apresenta três dimensões. Considera como a mais importante a dimensão tempo (preços intertemporais para um mesmo ativo). As outras duas são: padrão de qualidade, representando diferentes graus de qualidade dos bens sujeitos à entrega e a dimensão espacial, representando diferentes locais de entrega.

Conforme exposto em Rochelle (1997, p.7), a base comporta-se de forma diferente para commodities estocáveis e não-estocáveis. Kamara (1982) também procede a uma separação entre esses dois tipos de commodities, situando-as, porém, no que ele classifica como dimensão tempo (base intertemporal).

Para commodities estocáveis a diferença entre os preços à vista e futuro depende do custo de carregamento ${ }^{45}$ que, por sua vez, varia em função das condições de oferta e demanda observadas. Modelos de preços de equilíbrio mostram que, devido aos ajustes diários, um preço futuro representa especulação simultânea sobre o preço spot futuro e sobre as taxas de juros futuras instantâneas (Kamara, 1982, p.269). Contudo, em uma situação ceteris paribus, o preço futuro não excederá o preço à vista em uma magnitude maior do que o custo de carregamento pois, em caso contrário, apareceriam as possibilidades de arbitragem com o conseqüente nivelamento dos preços. No entanto, de uma forma mais geral, além dos custos de carregamento, a base também reflete as condições locais de oferta e demanda, tributação etc.

\footnotetext{
${ }^{45}$ Custo de armazenagem mais o juro pago para financiar o ativo, menos o rendimento obtido com o mesmo (Hull, 1996, p.77).
} 
No caso de commodities não-estocáveis, a teoria sobre a base não está bem desenvolvida. Os preços futuros devem representar uma antecipação do preço à vista para uma data no futuro. Como essa antecipação é feita com base nas informações disponíveis no mercado à vista, a chegada de novas informações faz com que a base se torne mais instável.

Para Marshall (1989, p.223), compreender o mecanismo da base é a chave para o entendimento do hedging. Quanto mais alta a correlação entre o preço disponível e o preço futuro no vencimento do contrato, mais efetivo se torna o contrato futuro como instrumento de proteção e mais baixo será o risco de base.

O risco da base é dividido em dois componentes: risco sistemático e risco aleatório. Mantendo-se somente o risco sistemático, além de a base tornar-se previsível, haveria a tendência de $\mathrm{o}$ preço futuro e o preço no disponível convergirem no vencimento do contrato. No entanto, quanto mais a base oscilar aleatoriamente maior será seu risco. $\mathrm{O}$ risco de base, considerado risco do hedging é, então, atribuído às flutuações imprevisíveis da base.

Nesse contexto, quanto mais a base variar, menor será a utilidade dos mercados futuros como veículo de transferência de riscos. Garcia e Sanders ${ }^{46}$, citados por Rochelle (1997, p.19), afirmam que quando o risco de base aumenta: a) a capacidade dos contratos futuros em transferir risco é reduzida; b) torna-se mais difícil avaliar o mercado num futuro próximo e identificar oportunidades de preços; e c) a utilização dos contratos futuros pode diminuir.

Portanto, como diz Marshall, entender a base é a chave para que os contratos futuros sejam úteis como instrumento de transferência de risco e sejam utilizados pelos players potenciais. Mesmo porque, se os hedgers tomaram posição no mercado, eles

\footnotetext{
${ }^{46}$ Gancia, P. e Sanders, D.R. 'Ex Ante Basis Risk in Live Hog Futures Contract: Has Hedgers'Risk Increased?" The Journal of Futures Markets, 1996, 16(4):421-440.
} 
deixam de se preocupar com o movimento dos preços e passam a acompanhar as mudanças de base. Dessa forma, para que os hedgers potenciais sejam atraídos para o mercado futuro o risco de base deve se apresentar menor do que o risco de preço no mercado disponível.

Em geral, o risco de base é maior quando aumenta a diferença de tempo entre a contratação de um hedging (compra ou venda de contratos, oposta à posição detida no mercado físico) e o vencimento do compromisso assumido pelo hedger no mercado disponível. Assim, o ideal é escolher um contrato com vencimento posterior, o mais próximo possível do compromisso no fisico (Hull, 1996, p.97). Este procedimento está ligado ao fato de que uma melhor performance para o hedging depende da capacidade de se prever a base no vencimento do contrato futuro (Kenyon et al., 1991) ${ }^{47}$

Por último, num mercado com pouca liquide ${ }^{48}$ os preços futuros estão mais sujeitos a oscilações e quanto mais flutuarem esses preços, maior a variação da base e maior seu risco. $\mathrm{O}$ contrário seria também verdadeiro, quanto maior a liquidez, menor a volatilidade dos preços futuros e, conseqüentemente, menor o risco de base (Rich, citado por Rochelle, 1997, p.34) ${ }^{49}$. Portanto, quanto maior for o conhecimento da base, tanto mais efetivo poderá tomar-se o hedging.

\subsubsection{Razão ótima de hedging/eficiência}

Segundo Johnson (1960, p.150), se um trader tem expectativas somente em relação às variações nos preços relativos, ele toma uma posição um-por-um nos

${ }^{47}$ Kenyon, D., Bainbridge, B. \& Emst, R. 'Tmpact of Cash Settlement on Feeder Cattle Basis". Western Journal of Agricultural Economics, 16(1):93-105, 1991. Citados por Rochelle (1997, p.53).

${ }^{48}$ A liquidez pode ser entendida como a facilidade para se encontrar uma contraparte para a posição que se quer assumir. Assim, num mercado com uma quantidade apreciável de hedgers, especuladores e arbitradores, supõo-se que a todo momento encontram-se pessoas que queiram comprar ou vender contratos. Se a ordem de compra ou venda emitida é cumprida normalmente de forma rápida, pode-se dizer que o mercado tem alto grau de liquidez.

49 Rich, D.R. "Feeder Cattle Cash Settlement: Impacts on Basis Variability and Behavior in Selected U.S. Markets". Urbana, 1990, 118 p. University of Minois (M.S. Thesis). 
mercados fisicos e futuro. Contudo, esse tipo de hedging pode contar com um elemento especulativo, dependendo de sua reação em relação à esperada variação nula dos preços relativos.

Dessa forma, se há um elemento de especulação numa posição de hedging que corresponda à totalidade da posição mantida no fisico, deve haver, então, uma posição intermediária que possibilite a otimização da posição assumida. Essa é a razão ótima de hedging.

$\mathrm{Na}$ outra ponta, um hedging perfeito, que é praticamente impossível, seria aquele que eliminaria completamente o risco. Por isso um estudo de hedging com contratos futuros aborda, em essência, os caminhos pelos quais ele pode ser conduzido, de modo que sua eficácia seja a mais perfeita possível (Hull, 1996, p.87).

Segundo Marshall (1989, p.206), desenvolver um instrumento que permita estabelecer o nível ótimo de hedging implica em responder a duas questões: qual a combinação de futuros que maximiza sua eficácia? E, qual a razão ótima de hedging?

A quantidade de produto, a ser vinculado em uma operação de hedging, que maximiza a função utilidade do produtor depende do seu grau de aversão ao risco, do custo e da eficiência do hedging. Por outro lado, para Rolfo ${ }^{50}$ citado por Kamara (1982, p.263), a razão ótima de hedging para um produtor que tenha incertezas quanto à quantidade $e$ ao preço situa-se bem abaixo daquela para um produtor que esteja às voltas somente com incerteza quanto aos preços. Estes resultados podem ajudar a entender porque alguns mercados futuros são menos utilizados pelos agropecuaristas.

A razão de hedging é a proporção do tamanho da posição em contratos futuros com relação à posição detida no fisico. Essa razão normalmente difere de 1. Por trás

\footnotetext{
${ }^{50}$ Rolfo, J. "Optimal Hedging under Price and Quantity Uncertainty: The Case of a Cocoa Producer". Joumal of Political Economy, 1980, (88):100-116.
} 
desse fato pode-se lembrar que a pressuposição básica da teoria do portfolio, como relata Souza (1994, p.26), é que os hedgers levam em consideração os retornos esperados e os riscos no momento de decidir pelo nível ótimo de suas posições no mercado físico para cobrir os contratos futuros.

A par da teoria que envolve a questão, Hull $(1996$, p.100) a apresenta de forma simplificada. Para esse autor, a razão ótima de hedging é dada pela seguinte equação:

$$
\mathrm{h}^{*}=\rho \frac{\sigma_{\mathrm{S}}}{\sigma_{\mathrm{F}}},
$$

onde $\mathrm{h}^{*}$ é a razão ótima de hedging (minimiza a variância da posição do hedger); $\rho$ é o coeficiente de correlação entre a mudança no preço à vista $(\Delta S)$ e a mudança no preço futuro $(\Delta \mathrm{F})$, durante um período de tempo igual à duração do hedging; $\sigma_{S}$ é o desviopadrão de $\Delta S$ e $\sigma_{\mathrm{F}}$ é o desvio-padrão para $\Delta \mathrm{F}$.

Estimando-se uma regressão de $\Delta \mathrm{S}$ (variações no preço à vista), contra $\Delta \mathrm{F}$ (variações no preço futuro), $\mathrm{h}^{*}$ representa a inclinação dessa curva de regressão.

Como as decisões são tomadas em ambiente de risco, o hedger vai procurar cercar-se de instrumentos que lhe permitam reduzir o risco a uma dada taxa de retorno, ou aumentar o retorno a uma dada taxa de risco.

\subsubsection{A substitutibilidade entre os contratos futuros e a termo}

Falar em substitutibilidade entre bens ou serviços remete à questão da utilidade $\mathrm{e}$ de saber se o consumidor é indiferente à combinação específica que obtém entre os bens pretensamente substituíveis. Segundo Ferguson (1986, p.33), conforme o comportamento dos preços de mercado uma mercadoria pode ser substituída por outra, numa certa quantidade, de modo que o consumidor tenha o mesmo nível de satisfação, ou seja, permaneça na mesma curva de indiferença. 
Considerar o mesmo nível de satisfação, com bens ou serviços que se substituem, requer que o novo bem ou o novo serviço possa cumprir a finalidade que ao anterior era cometida. Assim, falar da possibilidade de que os contratos a termo substituam os futuros (e vice-versa) é admitir que, pelo menos em alguma medida, esses contratos tenham a mesma função econômica.

A função comum seria o papel de hedging, ou seja, na visão de um produtor rural, a capacidade de o contrato poder funcionar como um seguro contra queda de preços. Essa função seria desempenhada por ambos os contratos. No entanto, essa característica de "seguro" é combatida por autores como Working, Williams e Telser, por exemplo.

Para Telser (1981) e Telser e Higinbothan (1977), a função dos mercados futuros seria a de criar um mercado com alta liquidez e que incorporasse a certeza de que os contratos seriam honrados a um baixo custo de transação. Em um mercado futuro organizado e com tal configuração não importaria a identidade dos agentes. A clearing se encarregaria de fazer com que os contratos fossem cumpridos, assumindo a contraparte nas transações. A certeza de cumprimento das obrigações deriva da forma como a clearing e a própria bolsa são organizadas e dos ativos que a primeira possui, como reserva para situações extraordinárias.

Pensando-se na função econômica defendida pelos autores - liquidez e facilidade de transação entre estranhos -, não haveria como os contratos serem substitutos. A propósito, Telser $(1981$, p.5) defende a idéia de que os contratos a termo não seriam substitutos perfeitos entre si próprios por causa da identidade das partes, que é um fator importante nos contratos a termo ${ }^{51}$, e porque podem diferir, um dos outros, nas demais características.

\footnotetext{
${ }^{51}$ A identidade é um balizador da possibilidade de cumprimento do contrato. É uma medida de risco. Através da identidade é que se pode avaliar a idoneidade e a capacidade patrimonial das partes envolvidas.
} 
Uma outra questão importante na visão desse autor (1981, p.11/2), é que o interessado em comprar ou vender contratos futuros constitui um agente para negociar em seu nome, com recomendações precisas quanto à quantidade e o preço envolvidos. Já, quando o produto físico é envolvido, mais informações são requeridas. A mercadoria deve ser inspecionada, a qualidade verificada, a localidade de entrega determinada etc. Neste caso não basta dizer ao agente quanto se quer comprar ou vender e a que preço. Exige-se do agente conhecimento do produto, honestidade e familiaridade com as necessidades de quem lhe transmite as ordens de compra ou venda.

Negociar em contratos futuros permite ao interessado beneficiar-se das vantagens da especialização porque os agentes são supervisionados a um baixo custo. Reafirma-se, com base na visão de Telser, que, com as características de liquidez e de facilidade de negociação entre estranhos, exibida pelos contratos futuros, não há como os dois contratos se substituírem de forma perfeita. A propósito, "um contrato futuro apresenta a mesma vantagem sobre um contrato a termo como uma transação realizada com moeda apresenta em relação às transações por escambo" (Telser, 1981, p.12).

Por outro lado, a visão de Williams (1986), contempla o deslocamento da proteção/transferência de risco do centro das funções econômicas dos mercados futuros para o surgimento, em seu lugar, da possibilidade de o mercado funcionar como um "centro" de empréstimo temporário de commodities, alocando estoques escassos para as firmas cuja necessidade é maior no momento.

Nessa visão, o pit de negociações se torna importante, na medida em que é nesse local que "os preços emergem com notável ordem e sofisticada condição alocativa", não deixando muito espaço para que os contratos a termo exerçam a função de substitutos perfeitos para os contratos futuros. 
Na visão de Working (1970), também seria dificil considerar a substitutibilidade perfeita entre os dois contratos. Referido autor admite que os contratos futuros são substitutos temporários para operações no mercado fisico, eliminando a possibilidade de os contratos a termo desempenharem a mesma função, uma vez que espelham exatamente transações no mercado disponível.

Nelson (1985), por outro lado, incorpora em sua análise os contratos futuro e a termo, com sua capacidade de garantir preços (e, conseqüentemente, a renda), nas estratégias de comercialização dos produtores rurais. $\mathrm{O}$ autor registra que muitos economistas superenfatizam a característica comum desses contratos em facilitar vendas a futuro, tratando-os como se fossem substitutos perfeitos.

Para Nelson as principais diferenças como fluxo de renda, base e lumpiness resultam das diferentes características de padronização, forma de pagamento e forma de liquidação.

Devido à padronização dos contratos, principalmente quanto ao tamanho, a quantidade passível de ser protegida através de contratos futuros pode não se igualar à quantidade desejada para o hedging. Este desbalanceamento resulta num compromisso de venda futura de $x_{f}$ sacas, ao invés da quantidade desejada de $x_{p}$ sacas. A diferença entre essas duas quantidades, $x_{f}-x_{p}$, é chamada lumpiness (Nelson, 1985, p.16) e representa, então, o descasamento entre as quantidades que se deseja e que efetivamente se pode vincular em uma operação de hedging, devido ao tamanho dos contratos.

A lumpiness é especialmente importante para os pequenos produtores. Considere-se um produtor que deseja proteção para 160 sacas de café. Como os contratos de café da BM\&F são de 100 sacas, o hedging poderia ser feito pela venda de 1 ou 2 contratos. No primeiro caso haveria uma subproteção de 60 sacas (lumpiness de $37,5 \%$ do total desejado), enquanto no segundo caso haveria uma superproteção de 40 sacas, com uma lumpiness de $25 \%$. Já no caso de um grande produtor, cujo hedging 
desejado fosse de 10.060 sacas, haveria, igualmente, uma subproteção de 60 sacas ou uma superproteção de 40 sacas. Para este produtor a lumpiness seria de $0,6 \%$ do total desejado, no primeiro caso, ou de $0,4 \%$ no segundo.

Apesar de significativa para os produtores de menor porte, a lumpiness passa quase despercebida para os grandes produtores, não se constituindo em problema para esses.

Para Nelson, a segunda diferença entre os contratos a termo e futuro resulta dos diferentes fluxos de renda existentes. $O$ contrato a termo produz renda apenas em seu vencimento, enquanto nos contratos futuros há um fluxo de rendas e custos (originário dos requerimentos de margem, dos ajustes diários e de taxas/comissões) que abrange toda a vida do contrato.

Para o autor citado, a padronização do local de entrega e dos vencimentos provoca a terceira e importante diferença conceitual entre os dois contratos. As dimensões espacial e temporal freqüentemente fazem com que os preços a termo e futuro divirjam. A diferença entre esses preços, definida como base ${ }^{52}$, é importante porque as mudanças relativas entre as cotações dos contratos a termo e futuro afetam somente a lucratividade do hedging em futuros.

$\mathrm{Na}$ avaliação empírica procedida em seu trabalho, Nelson concluiu que a renda ou custo financeiros derivados da manutenção da margem, refletida pelos ajustes diários, não alcançaram magnitudes significantes em relação às mudanças de preço e da base $\mathrm{e}$, assim, podem ser ignoradas; os dados também ilustraram o declínio de importância da lumpiness conforme crescia o tamanho do hedging desejado. Na avaliação empírica restou a base como a diferença mais marcante entre os dois contratos.

\footnotetext{
${ }^{\$ 2}$ Para Nelson (1985, p. 18), a base assim definida representa a relação correta para a avaliação ex post dos contratos a termo e futuros, ao contrário da definição usual de base, dada como a diferença entre os preços spot e futuro.
} 
A palavra final de Nelson $(1985$, p.22) quanto à substitutibilidade entre os contratos a termo e futuros, pode ser encontrada na seguinte frase "os resultados desta análise implicam que os economistas não devem intercambiar livremente os contratos a termo e futuros em seus modelos. A metodologia correta e exata deve considerar ambos como alternativas possíveis de comercialização".

\subsection{Opç̃es}

$O$ produtor rural, ao vender sua produção através de $C P R$, presente uma necessidade de financiamento, fixa de forma antecipada o preço de entrega de sua mercadoria. A partir desse momento acabam-se suas preocupações acerca do risco de preço. Sua receita está previamente fixada.

No entanto, se houver alterações nas condições de oferta e demanda de seu produto, estas se refletirão no preço futuro. Se as mudanças provocarem um movimento baixista nos preços, a venda antecipada não só lhe terá propiciado recursos financeiros para a efetivação do plantio/condução da lavoura, como, também, terá servido como instrumento de hedging.

O que dizer se o movimento se der no sentido de alta dos preços? Duas podem ser as atitudes do produtor frente a esta questão: a) não se preocupa com o fato porque na negociação da CPR já garantiu uma razoável margem de lucro (além, obviamente, do valor econômico da antecipação de recursos obtida); ou b) lança mão dos mercados futuros ou de opções para garantir participação em eventuais altas de preços.

Em relação ao mercado futuro, o produtor pode abrir uma posição de caráter especulativo. Ao invés de assumir posição vendida, contrária àquela detida no fisico, o que seria natural, abre uma posição comprada. Estando long no mercado, caso os preços se elevem, passa a receber ajustes diários beneficiando-se da alteração do preço de seu produto. 
Uma atuação dessa natureza pode se revelar nociva ao produtor. Além dos custos normais relativos à transação, dos custos de disponibilização de margem e dos custos de monitoramento do mercado, pode se ver frente a uma realidade de preços em baixa. Nesse caso, além dos custos já citados, teria agravada sua situação pela necessidade de pagamento de ajustes à parte contrária, não compensado por posições no mercado físico.

Enquanto o hedging feito em mercados futuros ou a termo fixa um dado preço (um ponto no espaço de preços), a proteção através de opções fixa um limite mínimo ou máximo pelo qual o comprador da opção irá se garantir, estabelecendo, assim, um "seguro" contra a queda ou elevação de preços. Dessa forma, beneficia-se, no primeiro caso, dos movimentos de alta e, no segundo, dos movimentos de baixa.

Além da utilização dos mercados futuros em complementação a operações de CPR, uma outra alternativa disponível ao produtor é a utilização do mercado de opções. A principal vantagem desse mercado é a fixação de um preço mínimo quando se compra uma opção de venda (put) ou de um teto para variação dos preços quando se adquire uma opção de compra (call). Além destas duas posições (com suas respectivas contrapartes, os lançadores da opção), há uma série de estratégias que podem ser combinadas visando o hedging de posições ou a obtenção de resultados positivos.

As opções compõem-se de dois tipos: a) as opções de compra (call) que dão a seus compradores (ou titulares) o direito de comprar determinado ativo a um determinado preço (preço de exercício ou strike price), por um determinado período de tempo e a um determinado preço (prêmio); e b) as opções de venda (put), que dão a seus compradores o direito de vender um determinado ativo a um determinado preço, por um determinado período de tempo, pagando para isso um prêmio.

É importante notar que aos detentores das opções (call ou put) é atribuído um direito, mas não a obrigação de cumprir os termos do contrato (entrega ou recebimento 
do ativo subjacente). Se até o vencimento das opções o preço de mercado do ativo não se mostrar favorável ao exercício ${ }^{53}$, a opção vencerá sem ser exercida. Neste caso, os compradores das opções têm como despesa o prêmio pago, sendo este o lucro dos vendedores (também chamados lançadores).

Embora pelo lado comprador haja o direito e não a obrigação de exercer a opção, pelo lado vendedor há a obrigação em fazê-lo, desde que o comprador manifeste o desejo de exercê-la. A principal característica das opções é estabelecer um limite para as variações de preço. Um limite superior, quando se trata de uma call, ou um limite inferior, quando se trata de uma put. Esta característica é a de um seguro de preços na comercialização do ativo subjacente à opção, em especial as commodities agropecuárias. $O$ risco financeiro é limitado, enquanto o potencial de lucro é mantido.

Por outro lado, pago o prêmio no estabelecimento da posição, nenhuma outra despesa ou comprometimento é necessário. Para o comprador não há chamadas adicionais de margem nem há ajustes diários, com sua possibilidade de acarretar prejuízos e com os próprios custos relativos a esses ajustes. $\mathbf{O}$ comprador de uma opção sabe, desde o início, que a maior despesa (perda) em que pode incorrer é justamente o valor do prêmio.

As opções são classificadas em Americanas ou Européias. As primeiras podem ser exercidas a qualquer momento desde sua negociação até seu vencimento, enquanto as últimas só podem ser exercidas no vencimento.

Considerando que para o produtor a CPR é uma transação que só é finalizada em seu vencimento, quando ocorre a entrega do produto, as opções que melhor se adequam às comparações com esse título são as opções européias.

${ }^{53}$ Preço spot menor do que o preço de exercício nas call, e superior ao preço de exercício nas put. 


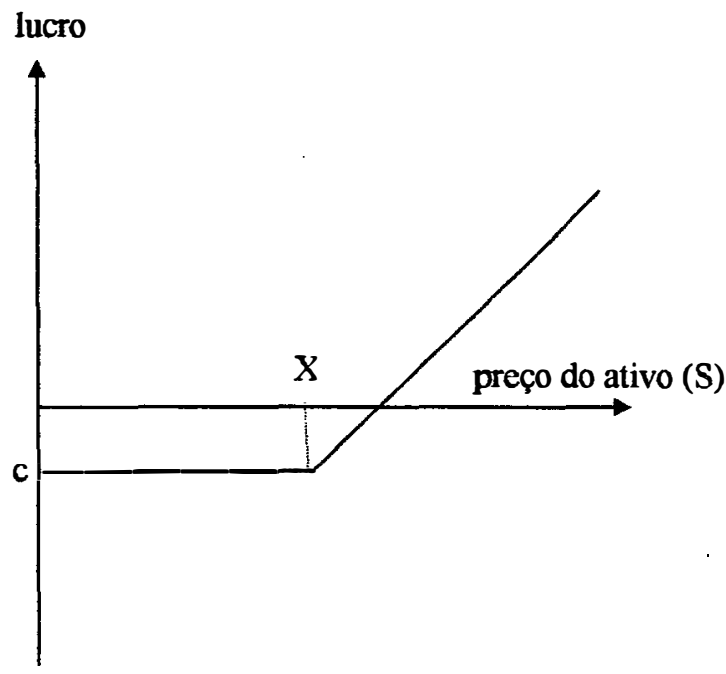

Figura 3-a: lucro resultante da aquisição de uma opção de compra européia ao preço de exercício $\mathrm{X}$.

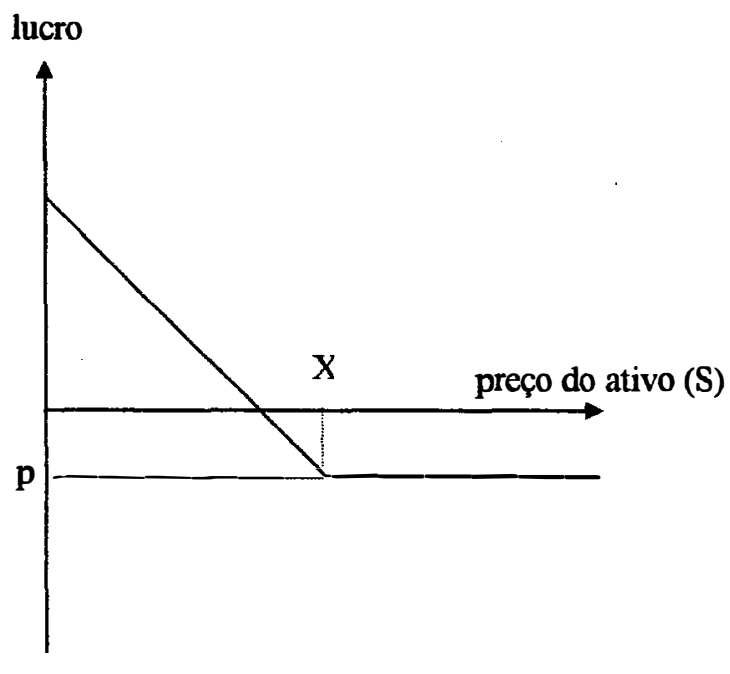

Figura 3-b: lucro resultante da aquisição de uma opção de venda européia, ao preço de exercício $X$.

As Figuras 3-a e 3-b indicam o comportamento das posições em opções européias ao longo das variações do preço do ativo subjacente. Nas opções de compra, que oferecem uma proteção contra elevações de preço, enquanto o preço do ativo (S) se situa aquém do (ou no) preço de exercício (X) a opção não é exercida e o detentor da opção perde o prêmio (c) pago. Quando S supera $X$, a opção é exercida, e o resultado para o titular da call começa a se alterar, tornando-se lucrativo quando o preço físico se toma maior que a soma do preço de exercício com o prêmio pago pela opção, ou seja, há lucro para o detentor da posição quando $S>X+c$.

No caso das opções de venda, que oferecem proteção contra quedas de preço, quando o preço do ativo é menor ou igual ao preço de exercício, a opção é exercida, ou seja, o ativo é vendido ao lançador da opção que é obrigado a honrar a posição assumida. Quando o preço do ativo é superior ao preço de exercício $(S>X)$, a opção não é exercida, significando que o ativo é vendido diretamente no mercado, causando prejuízo ao detentor da opção, de magnitude igual ao prêmio pago. 
Segundo Hull (1996, p.187), as opções podem estar dentro do dinheiro (in the money), no dinheiro (at the money) ou fora do dinheiro (out of the money). Uma opção dentro do dinheiro proporciona a seu titular um fluxo de caixa positivo caso seja exercida. Da mesma forma, uma opção no dinheiro resulta num fluxo de caixa zero, enquanto a fora do dinheiro apresenta fluxo de caixa negativo, se exercidas nessa situação. Uma opção de compra está dentro do dinheiro quando $S>X$, no dinheiro quando $\mathrm{S}=\mathrm{X}$ e fora do dinheiro quando $\mathrm{S}<\mathrm{X}$. Uma opção de venda está dentro do dinheiro quando $S<X$, no dinheiro quando $S=X$ e fora do dinheiro quando $S>X$. Uma opção será exercida se estiver dentro do dinheiro.

O valor intrínseco de uma opção é definido como o máximo de zero e o valor que teria se exercida imediatamente. Para uma opção de compra, o valor intrínseco é, portanto, $\max (\mathrm{S}-\mathrm{X}, 0)$; para uma opção de venda, $\max (\mathrm{X}-\mathrm{S}, 0)$, sendo que uma opção americana dentro do dinheiro deve valer pelo menos seu valor intrínseco. $O$ ideal para $o$ titular de uma opção americana dentro do dinheiro, segundo Hull, é aguardar o vencimento em vez de exercê-la imediatamente. Diz-se, então, que a opção possui valor tempo. Assim, o valor total de uma opção é a soma de seu valor intrínseco com seu valor tempo.

Para Silva (1996, p.56) o preço de venda de uma opção geralmente excede ao seu valor intrínseco, principalmente para opções americanas porque o valor tempo é sempre mantido positivo até a data de sua expiração. Esse autor considera duvidoso se o mesmo ocorre para opções européias, uma vez que, aproximando-se o vencimento o valor da opção pode não aumentar, dado que a opção só pode ser exercida na data de vencimento. Uma opção desse tipo pode estar dentro do dinheiro antes do vencimento e tornar-se fora do dinheiro próximo a essa data.

Como as opções americanas podem ser exercidas a qualquer momento, vale o ensinamento de Leuthold et al. $(1989$, p.321), para quem, quanto mais baixo o preço de exercício da call, ou mais alto o preço de exercício da put, maior a probabilidade de 
serem exercidas e maior é o valor intrínseco ostentado nessas situações. Já para Walmsley (1988, p.157), no vencimento de uma opção, apenas o valor do ativo e o preço de exercício é que determinam seu valor.

Um produtor rural que tenha o desejo de garantir um preço mínimo para o seu produto pode assumir uma posição comprada em put. Admitindo-se que a opção seja sobre o físico, para preços menores do que o preço de exercício exerceria a opção, entregando sua produção ao lançador, enquanto que, para preços superiores, venderia a produção diretamente no mercado. Essa estratégia assegura ao produtor um piso para a comercialização, incorrendo apenas na despesa com o prêmio.

Caso eventualmente quisesse conjugar uma operação dessa natureza com vendas através de CPR, em que o preço de exercício fosse o mesmo praticado na venda antecipada $\left(\mathrm{X}=\mathrm{P}_{\mathrm{cpr}}\right)^{54}$ a estratégia não teria qualquer significado (se anularia), uma vez que para preços inferiores ao preço de exercício o produtor já estaria protegido pela CPR. Para preços superiores, quando o normal é a venda direta no mercado (não exercício da opção), isso não se torna mais possível uma vez que a venda já foi realizada anteriormente e a entrega diferida tem que ser honrada, não restando produto para ser comercializado aos maiores preços vigentes.

Caso um produtor tenha realizado venda de CPR e queira se beneficiar de eventuais aumentos de preço, uma possibilidade ao seu dispor seria a aquisição de opções de compra.

Para verificação do resultado obtido com a combinação dessas duas alternativas $^{55}$, suponha-se que o produto físico tenha a trajetória de preços ascendentes,

\footnotetext{
${ }^{54}$ Deve-se notar que os preços só serão comparáveis quando se transportạr o preço praticado na CPR a futuro (mesma data da opção), a uma taxa de juros que represente as condições vigentes no mercado.

${ }^{55}$ Quando o produtor adota a estratégia de vender CPR e, ao mesmo tempo, adquirir opções de compra ele está, na realidade, criando uma op̧̧ão de venda sintética. Da mesma forma que essas duas estratégias combinadas resultam em uma put sintética, se, por exemplo, uma posição comprada em put for combinada com uma posição vendida em call, o resultado seria una posição sintética vendida em futuros.
} 
como na Figura 4, e que o preço de exercício da opção seja $X$, o qual ocorre para o tempo $T_{0}$. Nessa figura, tanto os preços físicos quanto o das opções são representados no eixo vertical (P), enquanto no eixo horizontal (T) é feita a representação do tempo.

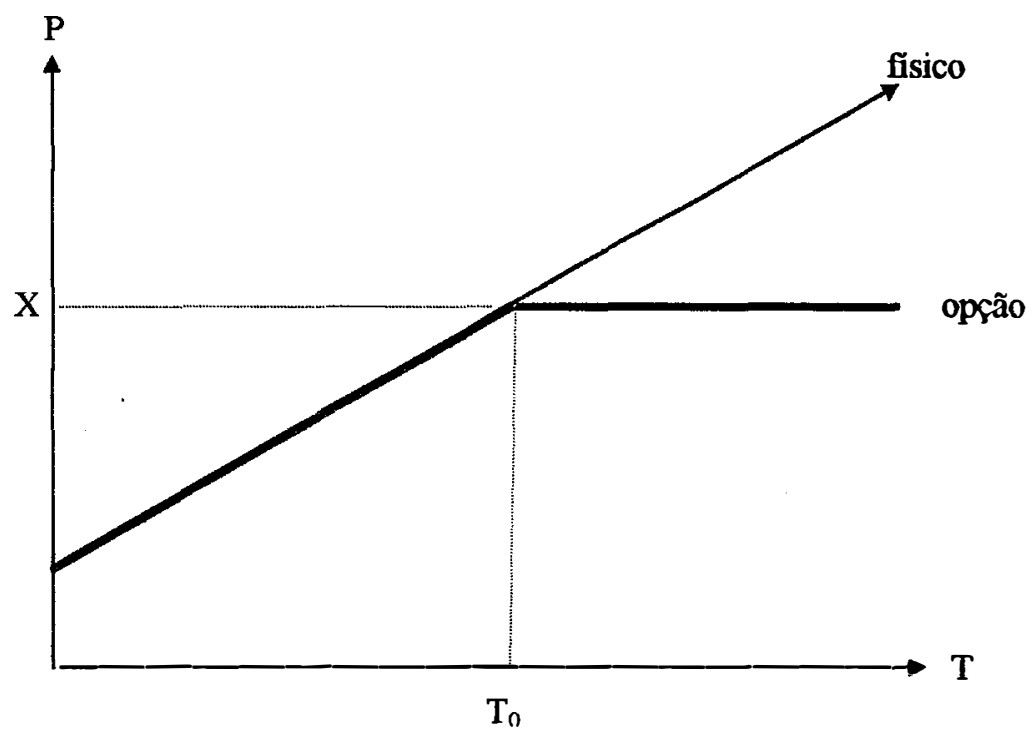

Figura 4 - Comportamento dos preços físico e de opção de compra ao longo do tempo.

Feitas essas suposições, a trajetória relevante para o comprador da call é representada pela linha mais encorpada do gráfico, ou seja, até $T_{o}$ prevalece os preços do físico, enquanto a partir desse ponto, o preço de exercício é considerado. Assim, a evolução do preço físico será acompanhada e comparada com o preço de exercício, visando à tomada de decisão.

Pela análise da Figura 4, pode-se perceber que até o tempo $\mathrm{T}_{0} \mathrm{o}$ comprador da opção não a exerce, uma vez que o preço de exercício supera o preço físico $(X>S)$. Se ele tivesse interesse no produto iria se abastecer diretamente no mercado, ignorando a possibilidade de exercer a opção pois isso seria feito a um preço maior do que o vigente no mercado disponível. 
A partir de $T_{o}$ o preço físico supera o preço de exercício $(S>X)$, tornando lucrativo o exercício da opção. A partir desse instante, o produtor que adquiriu a opção de compra para reforçar o negócio realizado através de CPR adquire o produto do lançador da call (que tem a obrigação de vender) e o vende diretamente no mercado, apropriando-se do diferencial de preços, no caso $\mathrm{S}-\mathrm{X}$, abstraindo-se o prêmio pago.

Por outro lado, admitindo-se que o produtor queira tão-somente beneficiar-se de movimentos de elevação dos preços, a alternativa de assumir posição vendida em call ou put não lhe traria qualquer resultado adicional pois o ganho máximo para o lançador da opção é o prêmio pelo qual é vendida. Além disso, haveria, ainda, os custos de monitoramento do mercado e, para garantir que a opção seja honrada, há chamada de margem com os custos adicionais que essa medida impõe.

\subsection{Considerações finais sobre o capítulo}

Como se viu neste capítulo, embora hajam movimentos que buscam informar e educar os produtores rurais, a participação desses agentes ainda é modesta tanto nos mercados futuros quanto no de opções. No entanto, a existência de contratos futuros para a commodity que produzem e negociam os beneficiará, no mínimo, com uma fonte sinalizadora de preços que embute as expectativas que o mercado está formando com relação àquele produto.

Relembra-se aqui a visão que Telser e Higinbothan (1977) tem a respeito dos mercados futuros. Para esses autores, a função dos mercados futuros seria a de criar um mercado com alta liquidez e que incorporasse a certeza de que os contratos seriam honrados a um baixo custo de transação, facilitando, portanto, as transações entre estranhos. Essa possibilidade permite, inclusive, que o produto seja negociado em nível nacional e até internacional, liberando os produtores da comercialização apenas em mercados locais. 
Discutiu-se, também, a substitutibilidade entre os contratos a termo e futuros. Embora esses contratos possam ser substitutos em alguma medida, concluiu-se que não há substitutibilidade perfeita entre ambos. Em análises que se queira fazer, ambas alternativas devem ser consideradas, não se admitindo o livre intercâmbio entre elas nos modelos analíticos (Nelson, 1985).

Buscou-se também apresentar, de forma breve e sucinta, as op̧̧ões como alternativa para os produtores, especialmente para aqueles que querem praticar vendas através de CPR mas se sentem temerosos de que os preços se elevem, deixando de aproveitar um momento de preços mais favoráveis. Para esses, haveria a possibilidade de conjugar a venda através de CPR com a aquisição de op̧̧ões de compra, o que, aliás, daria forma a um novo derivativo: uma op̧̧ão de venda sintética.

Para concluir, ao se falar em contratos futuros ou de opções, relembra-se que esses instrumentos apresentam duas características principais: a possibilidade de visualização de preços futuros e a possibilidade de servirem como instrumento de hedging. $\mathrm{Ou}$, nas palavras de Tomek (1987, p.21), tanto os futuros quanto as opções são veículos para o descobrimento de preços (price discovery) e hedging. 


\section{MATERIAL E MÉTODOS}

Com o lançamento da CPR não só os agentes do agribusiness se interessaram pelo título, mas, também, segmentos do mercado financeiro que, ao buscarem alternativas de aplicação para seus recursos, acabam fornecendo o funding necessário ao financiamento das atividades rurais a taxas mais atrativas do que aquelas cobradas pelo sistema financeiro.

A CPR pode ser emitida para validade entre as partes (vendedor/comprador) ou pode ser garantida por uma instituição financeira, através de aval. A partir de dados do Banco do Brasil (posição em 15/07/98), relativos às CPRs por ele avalizadas, percebese, em termos percentuais, o expressivo crescimento das operações. De um total de 121 contratos em 1994/95 chegou-se a 3.040 negócios efetuados, representando, no período, um crescimento da ordem de $90,55 \%$ ao ano, não obstante a pequena base inicial sobre a qual foi procedido o cálculo.

Quando o comprador de CPR pertence à cadeia do agribusiness a operação entre esses agentes se configura como uma transação a termo clássica. $O$ vendedor da CPR assume o compromisso de entregar o produto físico no qual o comprador está efetivamente interessado. Não havendo inadimplência por parte do vendedor, há sucesso no desfecho da transação.

No entanto, quando o comprador é apenas um detentor de poupança e procura alternativas de investimento, certamente não haverá interesse no produto físico. Para esses, alguns problemas se tornam evidentes: a) se houver o recebimento do produto 
objeto da CPR o investidor (se pessoa física) poderá arcar com o ICMS, reduzindo-se, portanto, seu lucro; b) caso receba o produto deverá encontrar um comprador para o mesmo, podendo sofrer nova redução de lucro, ou, até mesmo prejuízos, devido a fragilidade na ponta de negociação (caso percebida pelos demais agentes) ou, ainda, por desconhecer as peculiaridades do mercado. Além desses, custos como transporte, impostos interestaduais etc podem reduzir a lucratividade e o interesse dos investidores pelo título.

Dessa forma - dado que a CPR é um título novo e o mercado de derivativos agropecuários no Brasil ainda pode ser considerado incipiente -, foi situado no capítulo 2, fruto de pesquisa teórica, os ambientes contratual e operacional da CPR. Adicionalmente é utilizada neste trabalho a seguinte metodologia: a) efetivação de pesquisa de campo para aferição do "estado das artes" na forma de utilização da CPR; e b) avaliação quantitativa da CPR em seu papel de obtenção de recursos e de proteção contra movimentos de baixa dos preços.

\subsection{A pesquisa de campo}

Munhoz (1989, p.84) diz que a adoção de uma pesquisa de campo decorre da circunstância de inexistência, insuficiência ou incorreção de estimativas de informações julgadas necessárias ao desenvolvimento de um trabalho de investigação. Além disso, ainda de acordo com esse autor, a pesquisa de campo tem por objetivo a coleta de elementos não disponíveis que, ordenados sistematicamente e de acordo com processos adequados, possibilitem o conhecimento de uma determinada situação, hipótese ou norma de procedimento.

Na extensão do conceito, Ruiz $(1986$, p.50) defende a idéia de que a pesquisa de campo consiste na observação dos fatos tal como ocorrem espontaneamente, na coleta de dados e no registro de variáveis possivelmente relevantes para análises posteriores. 
Baseado nessas idéias, admite-se que para o caso da CPR um dos principais instrumentos de investigação não pode deixar de ser outro senão essa modalidade de pesquisa. $O$ título é novo, os dados não estão totalmente disponíveis, seja porque uma grande quantidade de negócios não é registrada na CETIP, seja porque os próprios dados obteníveis junto àquela Central possibilitam poucas conclusões analíticas. Além disso, mesmo que os dados de registro fossem amplamente conhecidos, como avaliar sua interação com os mercados de derivativos, uma vez que tais negócios (CPR $x$ futuros/opções) são transacionados em ambientes distintos e registrados também em locais distintos?

Como diz Munhoz (1989, p.16)

"a investigação científica, vista sob o ângulo de interesse da economia, poderia ser entendida como tendo o objetivo de conhecer a interrelação de variáveis, a fim de que se faculte atuar sobre determinada realidade, visando maximizar a utilização de fatores escassos - quer aumentando a eficiência econômica, quer elevando e diversificando os beneficios sociais" (ênfase do autor).

Outro não é o objetivo da investigação. Decifrar o modus operandi, que vem cercando a utilização da CPR pelo mercado, não só permitirá ganhos de eficiência econômica quando os agentes conhecerem o seu mapeamento, como também propiciará elevação de benefícios sociais ${ }^{56}$, uma vez que os emitentes desse título poderão se financiar no mercado, porém administrando melhor seus riscos e se beneficiando, mesmo que de forma parcial, dos movimentos de elevação dos preços das commodities comercializadas através desse instrumento.

As principais fontes de coleta de dados em pesquisa de campo são o questionário, o formulário e a entrevista. O questionário, segundo Marconi e Lakatos $(1986$, p.88) é um instrumento de coleta de dados, constituído por uma série ordenada de perguntas que devem ser respondidas por escrito e sem a presença de entrevistador. $\mathrm{O}$ formulário, por

${ }^{56}$ Certamente a pesquisa ajuda a evidenciar os principais problemas que ocorrem com o título e as respectivas possibilidades de aperfeiçoamento, cumprindo, dessa forma, o papel de oferecer à sociedade instrumentos de otimização para seus resultados. 
sua vez, seria o questionário respondido por indução e na presença de um entrevistador que pode esclarecer dúvidas na interpretação das perguntas.

A entrevista, por outro lado, conduzida normalmente de forma mais livre quanto ao encadeamento dos questionamentos "consiste no diálogo objetivo de colher, de determinada fonte, de determinada pessoa ou informante, dados relevantes para a pesquisa em andamento" (Ruiz, 1989, p.51).

Para cumprimento do objetivo de aferição do sentimento dos produtores que praticaram venda antecipada de café através de CPRs ${ }^{57}$ intermediadas pelo Banco do Brasil nas safras 96/97 e 97/98, acerca do título e de eventuais transações nos mercados futuros e de opções, será utilizado o formulário (ver Apêndice "A").

Devido ao tamanho da população, ao custo do levantamento de dados, ao tempo necessário para realizar as entrevistas e ao acesso aos elementos da população etc, normalmente se tem a necessidade de se recorrer a uma amostra, a qual, desde que convenientemente determinada, ou seja, desde que representativa da população, permite induções suficientemente precisas e confiáveis (Costa Neto, 1977).

Segundo Cochran (1965), a amostragem acidental simples, na qual a presente pesquisa se fundamenta, constitui-se em um processo para se selecionar $\boldsymbol{n}$ amostras tiradas de $N$ unidades, de forma que cada uma tenha igual probabilidade de ser selecionada, além de ser a modalidade que melhor se presta à apresentação da teoria da amostragem.

Para Cochran (1965, p.105), uma amostra demasiado grande implica em desperdício de recursos, enquanto uma muito pequena diminui a utilidade dos

\footnotetext{
${ }^{57}$ A escolha recaiu sobre as CPR de café porque são as que apresentam maior dinamismo e porque para essa commodity existem instrumentos derivativos (futuros e opções) tanto na BM\&F quanto em bolsas intemacionais.
} 
resultados. No entanto, esse mesmo autor descreve métodos para se determinar o tamanho da amostra, de forma que possa reproduzir as características da população.

$\mathrm{Na}$ seleção de uma amostra aleatória simples, as unidades da população são numeradas de 1 a $\mathrm{N}$, escolhendo-se, em seguida, uma série de números aleatórios compreendidos entre 1 e $\mathrm{N}$, através de uma tabela que contenha esses números, ou através de sorteio, sem reposição. No entanto, há que se definir se a amostra será estratificada $^{58}$, ou não, e seu respectivo tamanho.

Neste trabalho é utilizada a amostra aleatória simples estratificada, com grandeza amostral determinada a partir do método da repartição ótima presumível. Todavia, como as características da população não eram conhecidas a priori, a teoria recomenda que se proceda inicialmente a uma pesquisa piloto que permita determinar a proporção em que determinados atributos aparecem na população ${ }^{59}$.

\subsection{Os papéis de financiamento e hedging}

\subsubsection{A CPR como instrumento de financiamento}

A Cédula de Produto Rural constitui-se em um instrumento híbrido. Por um lado representa um ativo financeiro até o vencimento da cédula e, por outro, um contrato a termo com entrega diferida e preço ajustado e quitado na emissão do título.

Já que a CPR surgiu num momento de crise fiscal e de escassez de recursos para o financiamento das atividades produtivas rurais, o principal papel para o qual foi criada

\footnotetext{
${ }^{58}$ Quando a população se divide em subpopulações (estratos), é razoável supor que, de estrato para estrato, 0 comportamento das variáveis seja substancialmente diverso, mantendo-se, contudo, homogêneo no interior de cada estrato.

59 A definição da grandeza amostral e sua distribuição entre os estratos foi feita de acordo com Cochran (1965), consultando-se, adicionalmente, Som (1996).
} 
foi o de servir como instrumento de financiamento privado das safras, auxiliando no escoamento da produção através da comercialização antecipada.

Anteriormente à comercialização via CPR, o mercado vinha criando alternativas de financiamento principalmente sob o manto daquelas operações de escambo, conhecidas no mercado pelo jargão "troca-troca". A expectativa era de que, com o advento da CPR, os encargos financeiros passassem a situar-se em níveis mais aceitáveis para a atividade rural.

Na seção 2.3.4, que trata do processo de formação dos preços da CPR, foi introduzida a inequação (1) que serve para balizar as decisões do produtor em sua decisão de venda de CPR. A partir daquele modelo, numa análise ex post, a equação adequada para aferir o custo financeiro para o emitente da CPR é dada por:

$$
P_{\text {cpr }}=\frac{P_{f}}{(1+i)^{n / 360}}
$$

onde $\mathrm{P}_{\mathrm{cpr}}$ é o preço por saca recebido pelo produtor no ato da venda da CPR; $\mathrm{P}_{\mathrm{f}}$ é o preço futuro $\mathrm{BM} \& \mathrm{~F}$, em reais, do contrato com vencimento mais próximo ao da CPR; $n$ é o número de dias entre a emissão e o vencimento da CPR e $i$ é a taxa anual de juros.

Como, pelos dados, $\mathrm{P}_{\mathrm{cpr}}, \mathrm{P}_{\mathrm{f}}$ e $n$ são conhecidos, resta determinar a taxa $i$ que, por manipulação algébrica, é dada, em termos percentuais, por:

$$
\mathrm{i}_{\mathrm{cpr}}=\left[\left(\frac{\mathrm{P}_{\mathrm{f}}}{\mathrm{P}_{\mathrm{cpr}}}\right)^{360 / \mathrm{n}}-1\right] \times 100
$$

Para efeito de se averiguar o desempenho da CPR, enquanto instrumento de captação de recursos, a taxa $\mathrm{i}_{\mathrm{cpr}}$ será comparada à taxa over e à taxa de capital de giro anuais. A taxa over é uma taxa nominal mensal, divulgada diariamente, que remunera as 
operações com títulos públicos (somente em dias úteis) quando da realização dos leilões pelo Banco Central. Essa taxa é um balizador do mercado financeiro.

Seja $i_{\text {om }}$ a taxa over como publicada nos jornais e revistas especializados (taxa nominal mensal). Para que se tenha a taxa over anual $\left(i_{o a}\right)$, comparável à taxa $i_{\text {cprr }}$, são necessárias algumas operações.

Para a dedução da fórmula que fornece a taxa over anual, todas as taxas utilizadas serão consideradas na forma unitária. Assim, dada uma taxa over nominal mensal $\left(i_{o m}\right)$, em termos percentuais, sua taxa diária equivalente $\left(i_{e d}\right)$, na forma unitária, é dada por:

$$
i_{e d}=\left(\frac{i_{o m}}{30}\right) / 100=\frac{i_{o m}}{3000}
$$

Obtida a taxa unitária é possível calcular a taxa efetiva mensal, através da seguinte fórmula:

$$
i_{e m}=\left(1+i_{e d}\right)^{d u}-1
$$

onde $d u$ é o número de dias úteis do mês. A partir da taxa efetiva mensal, finalmente é possível calcular a taxa efetiva anual, dada em termos percentuais, pela fórmula:

$$
i_{o a}=\left[\left(1+i_{e m}\right)^{360 / d c}-1\right] \times 100
$$

onde $d c$ é o número de dias corridos do mês sob análise. Substituindo-se (6) em (7) e, esta, em (8), obtém-se:

$$
i_{\text {oa }}=\left[\left(1+\frac{i_{\text {om }}}{3000}\right)^{360 . d u / d c}-1\right] \times 100
$$

A taxa de capital de giro, obtida em termos anuais, porém com informação semanal (Dinheiro Vivo Agência de Informações), necessita (para não distorcer a 
análise) de uma correspondência diária com os dados de emissão das CPR. Para tal correspondência pode-se utilizar o método de interpolação linear.

Finalmente, para o cálculo dos deságios (d), em termos percentuais, a fórmula adequada é dada por:

$$
d=\frac{P_{f}-P_{\text {cpr }}}{P_{f}} \times 100
$$

\subsubsection{A CPR como instrumento de hedging}

Ao que indica a literatura, Black (1976) foi o pioneiro em relacionar o preço dos contratos a termo ao preço dos contratos futuros. Esse autor, utilizando suposições do modelo Black-Scholes de precificação de opções e o instrumental do modelo de precificação de ativos (Capital Asset Pricing Model-CAPM), desenvolveu um modelo que determina o valor das opções e o valor dos contratos a termo em função dos preços futuros.

No caso do contrato a termo, a conclusão foi de que seu valor é dado pela diferença entre os preços futuros e a termo, descontado ao presente pela taxa de juros de curto prazo.

Além de Black, outros autores trabalharam nessa linha de relacionar os preços a termo a preços futuros, discorrendo sobre o valor desses contratos. Podem ser citados como exemplos: Richard e Sundaresan (1981), Jarrow e Oldfield (1981), Cox et al. (1982) e French (1983).

No entanto, do ponto de vista mais específico de avaliar as diferenças entre o hedging utilizando contratos a termo e contratos futuros, inclusive com uma avaliação empírica, o trabalho de Nelson (1985) é que o faz. 
Para Nelson, antes da colheita, no instante $t$, o produtor contrata para entrega no período da colheita, $t^{*}$, uma parcela $\mathrm{x}_{\mathrm{p}}$ de sua produção. $\mathrm{Na}$ colheita, $\mathrm{o}$ produtor recebe $\mathrm{o}$ preço a termo $\mathrm{p}\left(\mathrm{t}, \mathrm{t}^{*}\right)$ para as $\mathrm{x}_{\mathrm{p}}$ sacas contratadas. Se $q$ representa a produção total comercializada em $\mathrm{t}^{*}$, então, a diferença $q-\mathrm{x}_{\mathrm{p}}$, representa as vendas líquidas realizadas ao preço spot $\mathrm{p}\left(\mathrm{t}^{*}, \mathrm{t}^{*}\right)^{60}$. Dessa forma, a renda bruta do produtor, que contrata parte de sua produção a termo $\left(\mathbf{R}_{\mathrm{fwd}}\right)$, é dada por:

$$
\mathrm{R}_{\mathrm{fwd}}=\mathrm{x}_{\mathrm{p}} \mathrm{p}\left(\mathrm{t}, \mathrm{t}^{*}\right)+\left(q-\mathrm{x}_{\mathrm{p}}\right) \cdot \mathrm{p}\left(\mathrm{t}^{*}, \mathrm{t}^{*}\right)
$$

Se manipulada algebricamente, a equação (11) pode ser escrita como:

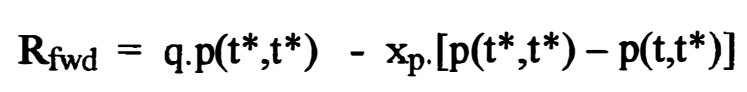

Ao contrário do hedging a termo, que proporciona uma única entrada de receita no final do contrato, a proteção por futuros gera, durante a vida do contrato, um fluxo de receitas e despesas, aqui indicado por $\mathrm{I}^{61}$. Além dișso, o produtor ao invés de entregar as $\mathrm{x}_{\mathrm{f}}$ sacas contratadas em futuro, normalmente encerra sua posição comprando, em $\mathrm{t}^{*}$, contratos ao preço futuro $f\left(t^{*}, T\right)$ que perfaçam a quantidade $x_{f}$ envolvida na transação $e$, ao mesmo tempo, vende no disponível as $q$ sacas produzidas.

A soma da renda apurada no disponível, com o resultado do hedging em futuros, mais as receitas/despesas (I) incorridas na conta "margem", proporciona a seguinte receita $\left(R_{\text {fut }}\right)$ líquida:

$$
R_{\text {fut }}=q \cdot p\left(t^{*}, t^{*}\right)+x_{f} \cdot\left[f(t, T)-f\left(t^{*}, T\right)+I\right]
$$

\footnotetext{
${ }^{60}$ Segundo Nelson $(1985, \mathrm{p} .16)$, nota de rodapé $\mathrm{n}^{\circ} 4$, o preço a termo em $\mathrm{t}^{*}, \mathrm{p}\left(\mathrm{t}^{*}, \mathrm{t}^{*}\right)$, se toma igual ao preço spot em $t^{*}$, desde que tal contrato requeira entrega imediata.

${ }^{61}$ Esse fluxo compreende a margem requerida, as taxas e comissões e as receitas (despesas) auferidas (incorridas) com relação aos ajustes diários. Dependendo da forma pela qual se constituiu a margem (dinheiro em espécie, $\mathrm{CDB}$, títulos públicos, capital de empréstimo etc), pode-se incorrer em receitas ou despesas. Além disso, há que se considerar o movimento favorável ou desfavorável dos ajustes diários. No balanceamento final I pode ser negativo ou positivo.
} 
onde $\mathrm{f}(\mathrm{t}, \mathrm{T})$ é o preço futuro no instante $\mathrm{t}$, anterior à colheita, e $\mathrm{T}$ representa a data de vencimento do contrato.

A base, para Nelson, ao invés de ser dada pela diferença entre os preços spot e futuro, é dada pela diferença entre os preços a termo e futuro. $O$ entendimento é de que essa forma expressa a correta relação para avaliar, de forma ex post, a relação corrente entre os contratos a termo e futuros.

O preço a termo em $t$, antes que o preço spot, indica a avaliação do mercado para $o$ valor da commodity. Isto faz com que a diferença no instante $t$, entre os preços futuro e disponível, seja irrelevante para a avaliação das alternativas de comercialização, disponíveis nos períodos anteriores à colheita.

Se $b\left(k, t^{*}, T\right)$ denota a base em um instante $k$, então o preço futuro no mesmo tempo, expresso em termos do preço a termo e da base, é dado por:

$$
f(k, T)=p\left(k, t^{*}\right)-b\left(k, t^{*}, T\right)
$$

Substituindo a equação acima em (13), enfatiza-se o efeito da base sobre o hedging em futuros e, conseqüentemente, sobre a receita. Dessa forma:

$$
R_{\text {fut }}=q \cdot p\left(t^{*}, t^{*}\right)+x_{f} \cdot\left[p\left(t, t^{*}\right)-b\left(t, t^{*}, T\right)-p\left(t^{*}, t^{*}\right)+b\left(t^{*}, t^{*}, T\right)+I\right]
$$

A variação da base entre os períodos da efetivação do hedging e da comercialização da produção aumenta ou diminui a renda futura.

Admitindo-se que $\Delta \mathrm{p}=\mathrm{p}\left(\mathrm{t}^{*}, \mathrm{t}^{*}\right)-\mathrm{p}\left(\mathrm{t}, \mathrm{t}^{*}\right)$ e que $\Delta \mathrm{b}=\mathrm{b}\left(\mathrm{t}^{*}, \mathrm{t}^{*}, \mathrm{~T}\right)-\mathrm{b}\left(\mathrm{t}, \mathrm{t}^{*}, \mathrm{~T}\right)$, então (15) pode ser escrita de forma mais simples, como:

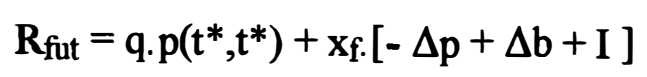


Suponha-se que existam dois produtores com idênticas produção e decisões de comercialização, exceto quanto à preferência por contratos a termo ou futuros. $\mathrm{O}$ primeiro fará o hedging utilizando apenas contratos a termo, enquanto o segundo utilizará somente futuros. No tempo $t$, o primeiro vende $\mathrm{x}_{\mathrm{p}}$ sacas em contratos a termo fazendo jus, ao final, à renda dada pela equação. (12). O segundo desejava vender essa mesma quantidade, no entanto, devido à lumpiness, vende $\mathbf{x}_{\mathbf{f}}$ sacas em futuros. A equação (16) expressa a renda desse produtor.

A diferença entre as rendas recebidas pelo produtor que fez o hedging através de futuros e aquele que utilizou contratos a termo, ponderada pela proteção desejada $x_{p}$, fornece a expressão necessária para comparar os contratos a termo e futuros como alternativas de comercialização.

Subtraindo-se, então, (12) de (16), dividindo por $\mathrm{x}_{\mathrm{p}}$ e agrupando os termos, temse:

$$
\frac{R_{f u t}-R_{f w d}}{x_{p}}=-\left(\frac{x_{f}-x_{p}}{x_{p}}\right) \Delta p+\frac{x_{f}}{x_{p}} \Delta b+\frac{x_{f}}{x_{p}} I
$$

A equação (17) constitui-se no modelo de Nelson e sugere que a lumpiness, as variações da base e os requerimentos de margens/ajustes diários constituem as potenciais diferenças para verificação empírica entre os contratos a termo e futuros como alternativas de comercialização.

$O$ coeficiente $\left(x_{f}-x_{p}\right) / x_{p}$ representa a proporção de descasamento entre $o$ hedging em futuros e o desejado/passível de realização via contratos a termo. Por causa da sub ou sobreproteção causadas pela lumpiness, a proporção continua exposta a variações de preço, como se pode visualizar no primeiro termo do lado direito da equação (17). A proporção $x_{f} / x_{p}$, que indica a parcela de produção vinculada em futuros, 
não está isenta do risco de base nem dos requerimentos de margem, conforme indicam o segundo e o terceiro termos do lado direito da equação citada.

Conforme se vê pela equação (17), expectativas de variação da base podem influenciar na escolha entre contratos futuros e a termo como instrumento de hedging. Uma variação positiva da base torna maior o resultado apurado com essa equação, contribuindo para um melhor resultado do hedging em futuros sobre aquele realizado por contratos a termo. Uma variação negativa indica uma diminuição na diferença de renda, mostrando prevalência do hedging a termo.

Quando $\left(R_{\text {fut }}-R_{f w d}\right) / x_{p}$ é positivo, significa que $R_{f u t}>R_{f w d}$, o que mostra ter sido o hedging em futuros mais vantajoso do que aquele realizado através de contratos a termo. Quando esse valor é negativo a situação se inverte.

\subsubsection{A utilização de opções na apropriação do diferencial positivo de preços}

Se o objetivo de um produtor rural é fixar um determinado preço mínimo, ficando livre para comercializar a produção se o preço de mercado ultrapassar o valor fixado, então, como solução de mercado, o caminho para o produtor é a aquisição de contratos de opção de venda, cujo preço de exercício seja coincidente com o preço mínimo pretendido.

Se, por outro lado, o produtor fixou o preço de parte de sua produção através da venda antecipada, via CPR, e tem a expectativa de que os preços irão se elevar, pode adotar a estratégia de adquirir opções de compra, as quais lhe darão a oportunidade de se apropriar do diferencial positivo de preços, caso este ocorra.

As opções, especialmente as de venda, traduzem para o produtor o sentimento de um autêntico seguro de preço. Não só um limite mínimo é estabelecido, como para adquirir tal seguro o produtor necessita pagar um prêmio. $\mathbf{O}$ prêmio, que é o preço pelo qual se adquirem as opções, depende de pelo menos quatro fatores (Marques e Mello, 
1997, p.98): preço de exercício, preço do ativo subjacente, do tempo decorrente entre a aquisição da opção e seu vencimento e da volatilidade de preços apresentada pelo ativo objeto.

De um modo geral o prêmio, em uma opção de compra, é função crescente do preço do ativo, do tempo decorrente para o vencimento e da volatilidade, sendo decrescente em relação ao preço de exercício.

No caso do café, as opções de compra são lançadas pela BM\&F em séries. Cada série recebe um código e é estabelecido um preço de exercício. A partir desses elementos, o mercado estabelece em leilão o prêmio (sopesadas as variáveis que o influenciam), o qual transmite o direito de comprar ou vender àquele preço.

Para uma análise ex post ter-se-ia diariamente a observação dos preços de exercício e de seus respectivos prêmios. Os prêmios incorporariam e refletiriam todas as variáveis que os influenciam, sendo, contudo, uma função decrescente do preço de exercício.

Para efeitos analíticos, admita-se que o prêmio de uma opção de compra (c) seja uma função linear decrescente do preço de exercício (X), dada por uma equação do tipo:

$$
c=a X+b
$$

onde $b$ é uma constante que expressa o coeficiente linear da reta e $a$ é uma constante negativa que determina sua inclinação.

Para verificação $a$ posteriori da obtenção de ganhos financeiros na utilização de uma estratégia combinada de venda de CPR com a concomitante aquisição de opções de compra, a seguinte condição deve ser satisfeita:

$$
\mathrm{S}-\mathrm{P}_{\mathrm{qpr}}>\mathrm{C}
$$


onde $\mathrm{S}$ é o preço spot no vencimento da CPR e $\mathrm{P}_{\text {cpr }}$ é o preço por saca, obtido com a venda da CPR, atualizado para a mesma data focal com $90 \%$ da taxa over ou com a taxa de remuneração da caderneta de poupança.

Os valores apurados indicarão se o produtor poderia ter utilizado com êxito a estratégia.

\subsection{Considerações finais sobre o capítulo}

Este capítulo, de cunho metodológico, mostrou os passos percorridos para a consecução dos objetivos propostos, ou seja, a indicação de que a inserção da CPR no rol dos contratos a termo e a visualização de seus ambientes contratual e operacional foi buscada a partir de pesquisa teórica, enquanto a verificação do sentimento dos produtores que praticaram venda antecipada de café, via CPR, nas safras 96/97 e 97/98 foi aferido através da realização de pesquisa de campo, cujo desenho baseou-se na amostragem aleatória simples, precedida de pesquisa piloto para caracterização de certos atributos presentes na população.

Além desses itens, desenhou-se o modelo que seria utilizado para aferição da CPR enquanto instrumento de financiamento, ao mesmo tempo que apresentando-se o modelo de Nelson, foram criadas as condições para verificação da CPR enquanto instrumento de hedging, contrastando-a com a proteção via mercados futuros. Adicionalmente, foi indicado o instrumental analítico que permitiria aferir a possibilidade de o emitente de CPR apropriar-se de eventuais diferenciais positivos de preços, através da aquisição de opções de compra. 


\section{DISCUSSÃO E ANÁLISE dOS RESULTADOS DA PESQUISA DE CAMPO}

\subsection{Aspectos Gerais}

Considerando que a CPR é um título ainda recente, com séries de dados que não englobam todos os negócios realizados na economia e considerando, ainda, a dualidade de seu papel, ao servir como mecanismo de financiamento e ao servir como instrumento de comercialização antecipada, proporcionando proteção contra queda de preços, levouse a efeito uma pesquisa de campo que tinha por objetivo aferir o "estado das artes" na utilização da CPR de café arábica, visando observar o perfil dos produtores que a utilizaram, o nível de satisfação, a forma de utilização do instrumento e a existência de negociação concomitante em contratos futuros/de opções etc.

Dado o fato de ser o Banco do Brasil a principal instituição financeira a operar no segmento, dando aval aos títulos e assegurando a entrega do produto ao comprador, o universo amostral foi o dos produtores que emitiram CPR, nas safras 96/97 e 97/98, com interveniência daquele banco.

Nessas duas safras foram emitidas 650 cédulas, envolvendo 390 produtores, cuja distribuição por microrregiões encontra-se na Tabela 5. Analisando-se essa tabela, percebe-se que foram emitidas CPR de café em apenas 3 estados, destacando-se Minas Gerais, com $78,2 \%$ das transações, secundado por São Paulo, com $20,3 \%$, enquanto ao Paraná coube a modesta quantia de $1,5 \%$ do total de negócios efetivados.

Do ponto de vista da diversidade de produtores, no Paraná houve maior atomização na emissão de cédulas. Os 10 negócios registrados foram efetivados por 9 
produtores, sendo que um único produtor emitiu mais de 1 cédula. $\mathrm{O}$ segundo estado em diversidade de produtores foi Minas Gerais, com 508 cédulas emitidas por 342 produtores, proporcionando uma média de 1,5 cédula por produtor. Para São Paulo, esse quadro se alterou. Foram 132 negócios firmados por 39 produtores, representando uma média de 3,4 cédulas por produtor.

Tabela 5. CPR de café avalizadas pelo Banco do Brasil: safras 96/97 e 97/98 (distribuição por microrregião)

\begin{tabular}{|c|c|c|c|c|c|c|}
\hline MICRORREGIÃO & $\begin{array}{r}\text { CPRs } \\
\text { emitidas }\end{array}$ & $\begin{array}{l}\text { número de } \\
\text { emitentes }\end{array}$ & $\begin{array}{l}\text { qtd.fisica (em } \\
\text { sacas } 60 \mathrm{~kg} \text { ) }\end{array}$ & $\begin{array}{r}\text { média por } \\
\text { produtor }\end{array}$ & $\begin{array}{l}\text { qtd.fisica (em } \\
1.000 \mathrm{~kg})\end{array}$ & Valor - R\$ \\
\hline Alfenas & 34 & 23 & 11.000 & 478 & 660.000 & $1.738 .621,62$ \\
\hline Araxá & 37 & 27 & 7.060 & 261 & 423.600 & $1.325 .295,00$ \\
\hline Campo Belo & 24 & 24 & 3.400 & 142 & 204.000 & $598.101,90$ \\
\hline Divinópolis & 1 & 1 & 700 & 700 & 42.000 & $128.527,14$ \\
\hline Lavras & 6 & 6 & 1.100 & 183 & 66.000 & $164.661,18$ \\
\hline Manhuaçu & 2 & 2 & 600 & 300 & 36.000 & $123.500,04$ \\
\hline Oliveira & 20 & 17 & 5.200 & 306 & 312.000 & $902.449,80$ \\
\hline Paracatu & 3 & 3 & 1.000 & 333 & 60.000 & $204.143,88$ \\
\hline Passos & 22 & 20 & 5.200 & 260 & 312.000 & $985.578,64$ \\
\hline Patos de Minas & 88 & 55 & 32.400 & 589 & 1.944 .000 & $5.291 .170,80$ \\
\hline Patrocínio & 95 & 38 & 45.200 & 1.189 & 2.712 .000 & $6.586 .531,62$ \\
\hline Piumhi & 28 & 17 & 8.500 & 500 & 510.000 & $1.453 .029,78$ \\
\hline Poços de Caldas & 33 & 16 & 13.100 & 819 & 786.000 & $1.707 .512,48$ \\
\hline Sta.Rita Sapucaí & 20 & 15 & 6.200 & 413 & 372.000 & $1.064 .132,34$ \\
\hline São Lourenço & 1 & 1 & 600 & 600 & 36.000 & $120.000,00$ \\
\hline S.SebastiãoParaíso & 33 & 24 & 10.700 & 446 & 642.000 & $1.850 .586,18$ \\
\hline Três Marias & 1 & 1 & 100 & 100 & 6.000 & $11.610,00$ \\
\hline Uberaba & 3 & 3 & 1.300 & 433 & 78.000 & $213.000,00$ \\
\hline Uberlândia & 8 & 5 & 3.800 & 760 & 228.000 & $710.530,02$ \\
\hline Unaí & 1 & 1 & 1.000 & 1.000 & 60.000 & $226.200,00$ \\
\hline Varginha & 48 & 43 & 12.204 & 284 & 732.250 & $2.013 .924,31$ \\
\hline MINAS GERAIS & 508 & 342 & 170.364 & 498 & 10.221 .850 & $27.419 .106,73$ \\
\hline Apucarana & 1 & 1 & 100 & 100 & 6.000 & $19.000,02$ \\
\hline Cornélio Procópio & 9 & 8 & 21.500 & 2.687 & 1.290 .000 & $4.388 .670,00$ \\
\hline PARANA & 10 & 9 & 21.600 & 2.400 & 1.296 .000 & 4.407.670,02 \\
\hline Batatais & 72 & 12 & 45.300 & 3.775 & 2.718 .000 & $5.440 .012,96$ \\
\hline Franca & 33 & 11 & 12.400 & 1.127 & 744.000 & $2.190 .522,62$ \\
\hline Limeira & 2 & 2 & 1.200 & 600 & 72.000 & $208.162,14$ \\
\hline Marília & 3 & 3 & 1.200 & 400 & 72.000 & $220.280,16$ \\
\hline Pirassununga & 2 & 1 & 400 & 400 & 24.000 & $73.020,00$ \\
\hline Ribeirão Preto & 1 & 1 & 1.000 & 1.000 & 60.000 & $160.000,20$ \\
\hline São João Boa Vista & 19 & 9 & 5.810 & 646 & 348.600 & $933.677,21$ \\
\hline SÃO PAULO & 132 & 39 & 67.310 & 1.726 & 4.038 .600 & $9.225 .675,29$ \\
\hline BRASIL & 650 & 390 & 259.274 & 665 & 15.556 .450 & 41.052.452,04 \\
\hline
\end{tabular}

Fonte: Banco do Brasil - UEN RURAL E AGROINDUSTRIAL - GECOM/BBCPR NOTA: as cidades foram classificadas por microrregiōes, de acordo com classificação do IBGE. 
Com relação à média de sacas por produtor, os números são de 498, $1.726 \mathrm{e}$ 2.400, respectivamente para Minas, São Paulo e Paraná.

Analisando-se os números envolvidos, inclusive a média de sacas por CPR, onde em Minas o número obtido foi de 335, enquanto para o Paraná e São Paulo foram, respectivamente, 2.160 e 510 , infere-se que no primeiro estado os produtores que transacionaram CPR nas duas safras consideradas são de menor porte do que aqueles dos outros estados.

Quando se pretende estudar por amostragem uma população cujas características sejam desconhecidas, a teoria sugere a realização de uma pesquisa piloto para determinação dos atributos que vão pautar o estudo principal.

Como no caso da CPR o desconhecimento era total, foi realizada pelo autor deste trabalho uma pesquisa piloto nas cidades de Patrocínio, no cerrado mineiro, e de Três Pontas, no sul de Minas (microrregião de Varginha), para levantamento dos atributos da população e definição das proporções que serviriam para a determinação da grandeza amostral.

A partir do levantamento das proporções e da utilização da repartição ótima presumível obteve-se, do universo de emitentes de CPR, uma população amostral de 185 produtores, os quais, seguindo os critérios de definição de tamanho de estratos expostos em Cochran (1965), foram divididos em 62 produtores para o cerrado mineiro e 123 para as demais regiões do país.

O método adotado na aplicação dos formulários foi o de enviá-los para as agências do Banco do Brasil que intermediaram CPR com os produtores sorteados no processo de definição da amostra aleatória, para a devida entrevista. Esse fator permitiu que se adotassem as fórmulas de custo fixo na definição da grandeza amostral. 
No desenvolvimento da pesquisa, como muitos dos questionários estavam demorando a chegar, houve o envolvimento do autor deste trabalho, através de telefonemas e, até mesmo, através de deslocamentos até as cidades de domicílio dos produtores, visando a efetivação das entrevistas.

No cenário subjacente à exploração cafeeira, percebe-se que uma das preocupações atuais da cafeicultura é a busca pela descomoditização do produto. Zylbersztajn e Neves (1993, p.10) descrevem que a região do cerrado mineiro tem características de altitude, pluviosidade e solos excelentes para a produção de café de alta qualidade. Essa vocação para cafés de qualidade, aliada ao fato de ser uma região de incorporação à produção de café relativamente recente (o que pressupõe cafeicultores menos tradicionais/conservadores), certamente propiciaram que, em 1991, cinco entre dez produtores premiados no Concurso Illycafé de qualidade fossem da região de Patrocínio. Para 1992, esse número se elevou para nove entre os dez premiados.

Essa região se destaca na busca da descomoditização do café. Há um movimento organizado em associações, cuja união deu origem ao Conselho das Associações dos Cafeicultores do Cerrado-CACCER, cujo objetivo é o de organizar a representatividade dos produtores da região, demarcar regiões de origem controlada, controlar a qualidade com padronização, selo de qualidade do produto, certificado de origem e prestação de serviços que vão desde a padronização até embarque e transporte (Zylbersztajn e Neves, 1993, p.11).

Além disso, os autores citados destacam, ainda, que a ação coordenadora do CACCER levou a definir padronização alternativa para o café produzido na região, a qual não ignora a tipologia baseada no número de defeitos, mas incorpora fava, cor e altitude da área de produção. Assim, surge a marca "Café do Cerrado" com logomarca e tipos diferenciados, indicando que um produto tradicionalmente tratado como uma 
commodity pode ser diferenciado, conseguindo levar ao produtor parte do prêmio pago pelo consumidor exigente, situado no final da cadeia agroindustrial.

Esse esforço de diferenciação do produto e de produção em bases mais empresariais levaram a que se admitisse no estudo a estratificação da amostra, com vistas a melhor apreender a realidade, através da separação dessa região em contraposição àquelas onde o café é produzido há mais tempo e, no geral, de forma mais tradicional.

\subsection{Perfil dos produtores}

A pesquisa de campo baseou-se em questionário pré-formatado, onde o primeiro dado de identificação dizia respeito à área cultivada e ao número de pés plantados. A Tabela 6 evidencia os resultados obtidos.

Tabela 6. CPR de café: área cultivada e número de pés plantados

\begin{tabular}{|c|c|c|c|c|c|c|c|c|}
\hline \multirow[b]{2}{*}{ INTERVALO } & \multicolumn{4}{|c|}{ CERRADO MINEIRO } & \multicolumn{4}{|c|}{ DEMAIS REGIŌES } \\
\hline & $\begin{array}{l}\text { qtd.pro- } \\
\text { dutores }\end{array}$ & $\%$ & $\begin{array}{l}\mathrm{n}^{0} \text { médio } \\
\text { hectares }\end{array}$ & $\mathrm{n}^{0}$ pés/ha & $\begin{array}{l}\text { qtd.pro- } \\
\text { dutores }\end{array}$ & $\%$ & $\begin{array}{l}\mathrm{n}^{0} \text { médio } \\
\text { hectares }\end{array}$ & $\mathrm{n}^{0}$ pés/ha \\
\hline 0 a 50 ha & 22 & 35,5 & 33,5 & 3.648 & 37 & 30,1 & 29,2 & 2.853 \\
\hline 51 a 100 ha & 19 & 30,7 & 72,8 & 3.104 & 29 & 23,6 & 78,6 & 3.197 \\
\hline 101 a 150 ha & 4 & 6,5 & 113,8 & 3.055 & 15 & 12,2 & 128,9 & 2.537 \\
\hline 151 a $200 \mathrm{ha}$ & 2 & 3,2 & 160,0 & 3.013 & 9 & 7,3 & 172,6 & 2.628 \\
\hline 201 a 250 ha & 3 & 4,8 & 226,7 & 3.280 & 11 & 8,9 & 238,0 & 2.659 \\
\hline 250 a $300 \mathrm{ha}$ & 3 & 4,8 & 280,0 & 4.286 & 5 & 4,1 & 291,8 & 2.015 \\
\hline acima 300 ha & 9 & 14,5 & 690,0 & 3.300 & 17 & 13,8 & 836,7 & 2.430 \\
\hline TOTAL & 62 & 100,0 & $171,4^{a}$ & $3.354^{6}$ & 123 & $\overline{100,0}$ & $204,5^{a}$ & $2.538^{b^{-}}$ \\
\hline
\end{tabular}

Fonte: dados da pesquisa

NOTAS: a média global de hectares por produtor.

b. número total de pés pelo número de hectares.

Pela análise da tabela percebe-se que, em ambos os casos, o número de produtores se concentra em áreas de até 100 ha, com a região do cerrado mineiro 
concentrando $66,2 \%$ dos produtores nessa faixa, enquanto para as demais regiões o número correspondente é de 53,7\%. A média de hectares dentro de cada intervalo é relativamente homogênea para as duas regiões consideradas, sendo mais significativa apenas para o último intervalo, aliás, em virtude de sua amplitude. No entanto, a média de hectares por produtor na região "demais" é $19,3 \%$ superior à média do cerrado mineiro.

Com relação ao número de pés por hectare ${ }^{62}$, em todos os intervalos é superada a marca de 3.000 na região do cerrado, enquanto na "demais", apenas no intervalo de 50 a 100 ha essa marca é superada.

Segundo Bacha $(1988$, p.19), a tecnologia vigente para as décadas de 70 e 80 preconizava o plantio de 1.666 ou 1.900 covas por hectare, enquanto os plantios ocorridos a partir de 1993 vem sendo conduzidos com nova tecnologia, nos sistemas semi-adensado, adensado ou superadensado, com $5.000,7.500$ ou 10.000 pés por hectare, respectivamente. Pela análise das médias regionais constantes da tabela inferese que o cerrado mineiro, por apresentar maiores médias de pés por hectare, é a região que vem utilizando mais intensamente a nova tecnologia de plantio.

Aliás, enquanto no cerrado as áreas de plantio são mais recentes, na "demais" a introdução da nova sistemática de plantio implantar-se-ia mais por substituição de lavouras antigas do que por expansão de área, como é o caso da primeira região. No entanto, para tal substituição deve-se levar em conta a relação custo/beneficio, até porque a primeira produção significativa só se dá aos 4 anos de idade do cafeeiro.

Ainda na linha de verificação do perfil, foi contemplado no questionário uma pergunta que buscava verificar se os produtores haviam emitido CPR para outras culturas/explorações. Houve apenas 4 respostas afirmativas, sendo 3 para a região do

\footnotetext{
${ }^{62}$ Não foi previsto no questionário a obtenção da quantidade de pés plantados diferenciando-se o sistema de plantio. Plantios superadensados e adensados coexistem com o sistema tradicional.
} 
cerrado e 1 para as demais regiões. Tal dado, aliado ao fato de que os produtores ouvidos eram domiciliados em regiões tipicamente cafeeiras, indica que a maioria tinha como exploração comercial apenas a cultura de café.

Buscando verificar se havia tradição na comercialização antecipada de café, apenas 18 produtores $(14,8 \%)$ na região "demais" manifestaram-se quanto à prática de contratação a termo de café, enquanto no cerrado a resposta afirmativa contemplou 19 dos 62 produtores ouvidos $(30,6 \%)$.

Entendendo-se que um dos temores que o produtor tem, ao vender sua safra (ou parte dela) de forma antecipada, é de os preços subirem após a efetivação da venda, causando-lhe o sentimento de prejuizo, buscou-se aferir se, concomitante à venda através de CPR o produtor havia feito operações nos mercados futuros ou de opções, visando precaver-se contra essa possibilidade ${ }^{63}$. Na região "demais", 2 produtores fizeram operações em futuros e 2 em opções simultaneamente às operações de CPR. No cerrado, 2 produtores operaram em futuros, enquanto em opções houve apenas 1 participante.

O questionário contemplava, também, uma questão a respeito de se os produtores alguma vez já haviam operado nos mercados de derivativos. $\mathrm{O}$ resultado encontra-se na Tabela 7.

Tabela 7. Utilização de contratos futuros/opções por cafeicultores emitentes de CPR

\begin{tabular}{|c|c|c|c|c|c|}
\hline \multirow[b]{2}{*}{ MODALIDADE } & \multicolumn{2}{|c|}{ CERRADO MINEIRO } & \multicolumn{2}{|c|}{ DEMAIS REGIỐES } & \multirow{2}{*}{$\begin{array}{c}\text { TOTAL } \\
\text { PRODUTORES }\end{array}$} \\
\hline & n $^{\circ}$ produtores & $\begin{array}{l}\% \text { s/total } \\
\text { do estrato }\end{array}$ & $\mathrm{n}^{0}$ produtores & $\begin{array}{l}\% \text { s/total } \\
\text { do estrato }\end{array}$ & \\
\hline Futuros & 24 & 38,7 & 28 & 22,8 & 52 \\
\hline Opç̃es & 5 & 8,1 & 9 & 7,3 & 14 \\
\hline
\end{tabular}

Fonte: dados da pesquisa

${ }^{63} \mathrm{O}$ produtor pode beneficiar-se de elevaçðes de preço adquirindo opções de compra ou comprando contratos futuros, por exemplo. 
Como se pode perceber pela análise da tabela, os produtores, em sua grande maioria, ainda não desenvolveram o hábito de se proteger contra oscilações de preços, administrando os riscos pertinentes através dos instrumentos derivativos. Em termos percentuais, a região do cerrado encontra-se na vanguarda na utilização de contratos futuros, com $38,7 \%$ de respostas afirmativas, enquanto na outra região esse percentual foi de $22,8 \%$.

$\mathrm{Na}$ pesquisa piloto realizada em Patrocínio e Três Pontas, as respostas afirmativas quanto à utilização de contratos futuros foram de 13 para a primeira cidade ( $50 \%$ do total) e de "zero" para a segunda, num universo de 15 produtores. Com relação a contratos de opções, os números respectivos foram de 4 e zero. Nas respostas os produtores, quase invariavelmente, diziam que a primeira experiência de operação nos mercados futuros havia se dado no próprio ano da pesquisa, 1998. Além disso, muitos realizaram suas operações porque obtiveram financiamento para as margens e ajustes diários, garantido por emissão de CPR.

Se se puder extrapolar a realidade vivenciada na pesquisa piloto, duas conclusões podem ser extraídas: a) que o trabalho de divulgação que tanto a BM\&F como o Banco do Brasil vem empreendendo necessita ser intensificado na região "demais"; e b) que a disponibilização de mecanismos, que atendam as necessidades do produtor rural ${ }^{64}$, podem fazer com que os agricultores lancem mão de recursos de administração de risco/garantia de receita como mecanismo auxiliar na comercialização de suas safras.

Os demais questionamentos envolvidos na pesquisa disseram respeito exclusivamente à utilização da $\mathrm{CPR}$, ainda com uma questão tipicamente de verificação do perfil dos emitentes. Tratava-se de verificar a freqüência de utilização do título como

\footnotetext{
${ }^{64}$ A Resolução 2.500, de 28/05/98, do BACEN permite a captação de recursos externos para financiamento de margens de garantia, ajustes diários e prêmios em operações nos mercados futuros e de opções. A partir dessa Resolução foram instituidos fundos para viabilizar tais operações.
} 
mecanismo de financiamento e como alternativa de fixação de preços. Os resultados encontram-se consolidados na Tabela 8.

Tabela 8. CPR - freqüência de utilização pelos emitentes

\begin{tabular}{ccccc}
\hline & \multicolumn{2}{c}{ CERRADO MINEIRO } & \multicolumn{2}{c}{ DEMAIS REGIÕES } \\
\cline { 2 - 5 } QUANTIDADE DE SAFRAS & n'produtores & $\%$ & n'produtores & $\%$ \\
\hline 1 safra & 26 & 41,9 & 83 & 67,5 \\
2 safras & 23 & 37,1 & 33 & 26,8 \\
3 safras & 8 & 12,9 & 6 & 4,9 \\
4 safras & 5 & 8,1 & 1 & 0,8 \\
\hline TOTAL & 62 & 100,0 & 123 & 100,0 \\
\hline
\end{tabular}

Fonte: dados da pesquisa.

O que chama mais a atenção na análise da Tabela 8 é o fato de que no cerrado mineiro $58,1 \%$ dos produtores ouvidos já haviam utilizado CPR mais de uma vez, enquanto na outra região considerada esse percentual atingiu apenas $32,5 \%$. Talvez uma das razões que explique essa diferença (este tópico será abordado adiante) seja o fato de que os produtores, de um modo geral, encontraram bastante dificuldade na entrega do produto, queixando-se freqüentemente de ter havido rigor na classificação.

\subsection{Aspectos relativos à operação de venda de CPR}

A primeira das questões desta subseção dizia respeito à razão pela qual os produtores optaram pela CPR em suas estratégias de financiamento/comercialização. Buscava-se verificar se o principal motivo tinha sido aquele para o qual a CPR foi criada (instrumento de captação de recursos), ou, se havia sido utilizada como mecanismo de apoio à comercialização, propiciando a venda antecipada do produto e garantindo o respectivo preço de venda. 0 questionamento, cujos resultados encontram-se consolidados na Tabela 9, contemplava esses dois aspectos e deixava em aberto, para resposta, se havia um outro motivo para escolha desse título.

Não obstante o fato de a pergunta conter apenas três alternativas, vários produtores insistiram em considerar como resposta uma mescla da primeira com a 
segunda alternativa, ou seja, a possibilidade de angariar recursos para suprir suas necessidades e, ao mesmo tempo, comercializar a produção de forma antecipada, fixando sua receita e definindo seu custo de produção na sistemática de equivalênciaproduto.

Tabela 9. Razão de utilização da CPR

\begin{tabular}{lcccc}
\hline \multirow{2}{*}{ RAZÃo } & \multicolumn{2}{c}{ CERRADO MINEIRO } & \multicolumn{2}{c}{ DEMAIS REGIÕES } \\
\cline { 2 - 5 } & $\mathrm{n}^{\circ}$ produtores & $\%$ & $\mathrm{n}^{0}$ produtores & $\%$ \\
\hline $\begin{array}{l}\text { a. falta de recursos para o custeio da } \\
\text { lavoura }\end{array}$ & 33 & 53,2 & 56 & 45,5 \\
$\begin{array}{l}\text { b. antecipação da comercialização, } \\
\text { garantindo preço }\end{array}$ & 16 & 25,8 & 35 & 28,5 \\
$\begin{array}{l}\text { c. outra } \\
\text { d. a+b }\end{array}$ & 1 & 1,6 & 4 & 3,2 \\
\hline TOTAL & 12 & 19,4 & 28 & 22,8 \\
\hline
\end{tabular}

Fonte: dados da pesquisa.

Mesmo admitindo-se a resposta híbrida, percebe-se que, para as duas regiões, o fator preponderante na venda de CPR foi a necessidade de obtençã̃o de recursos para o financiamento de gastos com a lavoura. No entanto, considerando a resposta de forma pura, adicionada à parcela de produtores que responderam de forma composta, nota-se que $45,2 \%$ dos produtores do cerrado tiveram a preocupação de antecipar a comercialização com o benefício de garantir o escoamento da produção e, ao mesmo tempo, fixar o preço de venda. Por outro lado, para a outra região considerada o percentual de produtores que tiveram a mesma preocupação atingiu $51,3 \%$.

Levando-se em conta a crítica usual de que o produtor sabe produzir mas não sabe comercializar sua produção, esses números, em torno de $50 \%$ para ambas as regiões, aliado ao número de produtores que já fizeram operações nos mercados futuros/de opções (ver Tabela 7), são um indicador de que a mentalidade pode estar mudando. Pode estar havendo o despertar para a necessidade de se precaver contra as freqüentes oscilações de preços que invariavelmente ocorrem com o café. 
Os produtores que responderam ter utilizado a CPR com outros fins, cinco no total, o fizeram com o objetivo de realizar investimentos; saldar dívidas contraídas anteriormente; com o intuito de se capitalizar e, até mesmo, pela oportunidade de realizar um bom negócio. Esta última assertiva certamente foi embasada em preços futuros favoráveis, com a possibilidade de obtenção de recursos no ato de emissão da cédula.

Sejam quais forem as razões que levaram os produtores a utilizar esse mecanismo de venda antecipada, saber se foi um bom negócio só é possível através da verificação do nível de satisfação com a utilização do instrumento. Quatro foram as alternativas de resposta, como se pode avaliar na Tabela 10.

Tabela 10. CPR - Nível de satisfação com a venda

\begin{tabular}{lcccc}
\hline & \multicolumn{2}{c}{ CERRADO MINEIRO } & \multicolumn{2}{c}{ DEMAIS REGIÓES } \\
\cline { 2 - 5 } & $\mathrm{n}^{0}$ de produtores & $\%$ & $\mathrm{n}^{0}$ de procutores & $\%$ \\
\hline Muito satisfeito & 26 & 41,9 & 33 & 26,8 \\
Satisfeito & 28 & 45,1 & 67 & 54,5 \\
Nada acrescentou & 4 & 6,5 & 3 & 2,4 \\
Insatisfeito & 4 & 6,5 & 20 & 16,3 \\
\hline TOTAL & 62 & 100,0 & 123 & 100,0
\end{tabular}

Fonte: dados da pesquisa.

Para os produtores que emitiram CPR de café, pode-se considerar que a cédula foi aprovada com boa imagem, eis que $87 \%$ dos respondentes do cerrado declararam-se entre satisfeitos e muito satisfeitos, enquanto esse nível atingiu nas demais regiões o percentual de $81,3 \%$.

Estar satisfeito com o instrumento não representa apenas a aprovação de um "título de crédito". A questão transcende esse aspecto, uma vez que não se trata só de 
um instrumento de captação de recursos mas, sim, constitui-se em uma nova filosofia de comercialização agrícola.

A CPR, ao permitir a venda antecipada da produção, leva o produtor a examinar seu custo de produção; as projeções de oferta e demanda que poderão afetar os preços; a possibilidade de ocorrência de fenômenos climáticos favoráveis ou adversos que possam influenciar preços etc. $\mathrm{O}$ balanceamento entre essas variáveis é que vai determinar sua decisão de venda e, além disso, ao examinar esses pontos levantados, o produtor vai agregar valor à sua estratégia de comercialização, só efetivando a venda a termo se perceber condições favoráveis para fazê-la. Com mecanismos nessa linha, pode-se dizer que o produtor se torna mais profissional na comercialização, podendo obter êxito na fase seguinte à produção, a qual normalmente maneja com eficiência e eficácia.

Uma outra causa que pode ter ajudado no nível de satisfação do produtor é o fato de as CPR serem apregoadas em leilão eletrônico para todo o País, dando oportunidade ao produtor de praticar a venda fora do mercado local facultando-lhe a liberação dessa limitação e permitindo, ao mesmo tempo, beneficiar-se de eventuais prêmios transferidos por intermediários que possuem contratos de fornecimento a terceiros em boas condições de preços.

Os produtores que entenderam que a CPR nada acrescentou, seja como instrumento de captação ou de viabilização de comercialização antecipada, atingiram apenas $6,5 \%$ no cerrado e $2,4 \%$ no restante do País.

Para os produtores que manifestaram-se insatisfeitos $(6,5 \%$ na primeira região e $16,3 \%$ na segunda), as principais causas disseram respeito à classificação do produto para entrega. Dentre os 24 respondentes neste quesito, houve 15 manifestações de que o produto não foi aceito pelo comprador, sendo que a não aceitação ligou-se à classificação. Houve quatro manifestações relativas ao "rigor" com que a classificação 
teria sido efetuada; uma manifestação relativa ao alto preço da armazenagem e outra dizendo que o armazém receptor era distante.

Das razões para a insatisfação, 2 produtores manifestaram que houve demora por parte do banco; 6 se manifestaram quanto à elevação dos preços após a venda, enquanto 1 assinalou o item que considerava ter sido alto o deságio.

A questão que buscava aferir as razões da insatisfação admitia assinalamento de mais de uma alternativa. O que se percebe, todavia, é que as principais queixas estiveram relacionadas à questão da classificação, ao ponto de um produtor (cuja resposta não foi contabilizada acima) dizer taxativamente que a "classificação [foi] rigorosa, em desacordo com os padrões vigentes no mercado".

O questionário previu uma questão aberta para sugestões ao aprimoramento da CPR. A resposta que mais emergiu nesse item (que será tratado adiante) foi a reclamação contra o sistema de classificação. Como interpretar a insatisfação com a classificação? Ela está sendo rigorosa, de forma à proporcionar um prêmio aos preparadores do café e aos compradores? Os produtores não foram devidamente alertados quanto ao padrão exigido (ou se esqueceram após receber um preço mais alto destinado a um café de qualidade superior)? Ou, ainda, será que há uma falha contratual, no sentido de que deveriam ser ofertadas CPR para qualidades inferiores? ${ }^{65}$ Buscar respostas para estas indagações abre campo para novas investigações.

\subsection{Avaliação financeira do negócio}

A avaliação financeira da venda a termo, através de CPR, não foi realizada de forma direta pelo produtor. Ao contrário, as questões foram feitas de forma indireta, utilizando-se perguntas comparativas. 
Tabela 11. Comparação da CPR com o custeio com recursos próprios ou de crédito rural

\begin{tabular}{lcccc}
\hline \multirow{2}{*}{ SENSAÇÃO } & \multicolumn{2}{c}{ CERRADO MINEIRO } & \multicolumn{2}{c}{ DEMAIS REGIÓES } \\
\cline { 2 - 5 } & $\mathrm{n}^{0}$ produtores & $\%$ & $\mathbf{n}^{0}$ produtores & $\%$ \\
\hline De que ganhou dinheiro & 32 & 51,6 & 65 & 52,8 \\
De que empatou & 23 & 37,1 & 44 & 35,8 \\
De que perdeu dinheiro & 7 & 11,3 & 14 & 11,4 \\
\hline TOTAL & 62 & 100,0 & 123 & 100,0
\end{tabular}

Fonte: dados da pesquisa.

A primeira das questões, evidenciada na Tabela 11, pedia para o produtor comparar a obtenção de recursos via CPR (que exige a fixação de preço) com a possibilidade de utilizar recursos próprios ou recursos de crédito rural, que o deixariam livre para comercializar o produto após a colheita, aos preços vigentes no mercado ${ }^{66}$. Fazendo-se essa comparação, centrando o pensamento na ótica de fixação de preço, perguntava-se: utilizando a CPR, ganhou dinheiro? Perdeu? Empatou?

Mais da metade dos produtores em ambas as regiões tiveram a sensação de que o resultado financeiro com a utilização da CPR superou as alternativas de utilizar recursos próprios ou de crédito rural ${ }^{67}$. Por outro lado, a sensação de perda financeira praticamente se igualou nas duas regiões, situando-se no patamar de $11 \%$.

A sensação de empate entre as alternativas atingiu pouco mais de $35 \%$ nas duas regiões. Essa sensação ex post pode não estar considerando outros fatores. Cabe, então, qualificar a questão.

\footnotetext{
${ }^{65}$ Após essas duas safras consideradas no estudo foram instituídas CPR para diferentes tipos de café.

${ }^{66}$ Deve-se lembrar que o produtor rural muitas vezes é tido como um especulador em potencial, sempre esperando que o preço de seu produto vai subir.

${ }^{67}$ Não se estava interessado em aferir se a possibilidade de utilizar recursos próprios ou de crédito rural estava à disposição do produtor, mas apenas considerar, para efeito de comparação, tal possibilidade.
} 
Suponha-se que na época de venda das CPRs os produtores estivessem descapitalizados ou que não houvesse possibilidade de se recorrer aos recursos do crédito rural, seja por inexistência/insuficiência, seja pelos limites de acesso a cada produtor. $\mathbf{O}$ que ocorreria? A inexistência de recursos levaria o produtor a se decidir entre duas alternativas ou a um mix entre ambas: efetuar operações "troca-troca" que lhe garantissem os insumos a serem aplicados na lavoura ou diminuir os tratos culturais como um todo (capinas e aplicação de insumos químicos).

A primeira alternativa, mesmo que the garantisse cuidar da lavoura de forma adequada, certamente o levaria a ter deságios superiores ${ }^{68}$ aos praticados na venda por CPR. Se antes a sensação era de "empate", neste caso ocorreria uma perda real.

A segunda possibilidade à sua disposição poderia ser mais grave. Sem recursos para as capinas e aplicação de insumos, a produção certamente iria cair, aumentando sobremaneira seu custo unitário, além de diminuir sua receita. $O$ prejuízo seria certo.

Outra questão que buscava aquilatar o resultado financeiro (ver Tabela 12) e, ao mesmo tempo, avaliar a receptividade quanto à nova forma de comercialização dizia respeito à continuidade ou não de utilização da CPR na presença de recursos de crédito rural fartos e limitados apenas às reais necessidades do produtor.

Tabela 12. Utilização da CPR na presença de crédito rural

\begin{tabular}{lcccc}
\hline & \multicolumn{2}{c}{ CERRADO MINEIRO } & \multicolumn{2}{c}{ DEMAIS REGIOES } \\
\cline { 2 - 5 } ATTTUDE & $\mathrm{n}^{\circ}$ de produtores & $\%$ & $\mathrm{n}^{\circ}$ de produtores & $\%$ \\
\hline Continuaria a utilizar CPR & 28 & 45,2 & 75 & 60,9 \\
Desistina de utilizar CPR & 26 & 41,9 & 36 & 29,3 \\
$\begin{array}{l}\text { Continuaria, dependendo das } \\
\text { condiçóes do mercado }\end{array}$ & 8 & 12,9 & 12 & 9,8 \\
\hline TOTAL & 62 & 100,0 & 123 & 100,0 \\
\hline
\end{tabular}

Fonte: dados da pesquisa.

NOTA: a. respostas espontâneas (não prevista no questionário)

${ }^{68}$ O produtor certamente negociaria com o fornecedor em situação de desvantagem, fragilizando-se na negociação. 
Se a cafeicultura do cerrado for considerada como administrada em bases mais modernas e empresariais, seria de se esperar que mesmo na presença de crédito rural a CPR continuasse a ser utilizada, principalmente por seu papel na administração de riscos via fixação de preço, ou devido ao papel que desempenha no escoamento da produção. No entanto, $41,9 \%$ dos produtores responderam que, diante do crédito rural farto e não limitado, desistiriam de utilizá-la. Para as demais regiões esse percentual foi de $29,3 \%$, indicando, neste caso, uma maior receptividade ao título.

Já para aqueles que continuariam com o título (45,2\% no cerrado e $60,9 \%$ no restante do País), a conclusão a que se chega é de que esses produtores vêem o instrumento como auxiliar em suas estratégias de comercialização por fixar preço, garantir o escoamento da produção e saber, de antemão, a magnitude de seus lucros pois tiveram fixadas sua receita e tiveram seus custos estabelecidos na moeda que lhes é peculiar, ou seja, produto. Para estes a CPR transcende a mera possibilidade de servir como instrumento captador de recursos.

Uma surpresa que a aplicação do questionário trouxe consigo foi a de exibir resposta para uma pergunta inexistente ${ }^{69}$. Esta tratava do fato de que continuariam a utilizar a CPR mesmo na presença de crédito rural, dependendo das condições do mercado. O percentual de produtores que vislumbraram esta alternativa atingiu $12,9 \%$ no cerrado mineiro e $9,8 \%$ na outra região considerada.

O que se pode afirmar a respeito dessa resposta é que os produtores enxergam com segurança o papel de instrumento de hedging desempenhado pela CPR, ou seja, num cenário de preços futuros descendentes não hesitariam em utilizar o título e o fariam como instrumento de apoio à comercialização.

\footnotetext{
${ }^{69}$ Pensou-se originalmente em proporcionar apenas duas alternativas de resposta para o produtor pois é sabido que quando há um meio termo, a tendência é de os respondentes optarem por essa solução.
} 
Avaliar financeiramente a CPR está muito ligado à observação do movimento de preços. Se os preços apresentarem trajetória descendente após a venda antecipada, com certeza haverá lucro para o produtor que escolheu essa estratégia. No entanto, se a trajetória for de preços ascendentes o produtor, mesmo obtendo lucro (se decidiu a venda em bases técnicas), poderá ter a sensação de perda ou, ainda, poderá privar-se do diferencial positivo de preços.

Ao temor de que os preços se elevem após a venda a termo, buscou-se verificar se os produtores tinham conhecimento de mecanismos que permitissem a apropriação do total ou de parte desses eventuais aumentos de preços ${ }^{70}$. Textualmente a pergunta recebeu a seguinte redação: "vendida a produção a preço fixado, você tem conhecimento de que pode se beneficiar de eventuais aumentos de preços através dos mercados futuros e de opções?". Os resultados encontram-se consolidados na Tabela 13.

Tabela 13. CPR: Conhecimento da existência de mecanismos de apropriação de aumentos de preços

\begin{tabular}{ccccc}
\hline & \multicolumn{2}{c}{ CERRADO MINEIRO } & \multicolumn{2}{c}{ DEMAIS REGIÓES } \\
\cline { 2 - 5 } CONHECIMENTO & $\mathbf{n}^{\circ}$ de produtores & $\%$ & $\mathbf{n}^{\circ}$ de produtores & $\%$ \\
\hline SIM & 37 & 59,7 & 67 & 54,5 \\
NÃO & 25 & 40,3 & 56 & 45,5 \\
\hline TOTAL & 62 & 100,0 & 123 & 100,0 \\
\hline
\end{tabular}

Fonte: dados da pesquisa.

Em ambas as regiões consideradas mais de $54 \%$ dos produtores responderam ter conhecimento de mecanismos que permitem a apropriação de eventuais elevações de preços, mesmo que já os tenham fixado anteriormente. Como, em operações complementares às emissões de $\mathrm{CPR}$, apenas 4 produtores assinalaram ter operado em

\footnotetext{
${ }^{70} \mathrm{O}$ produtor rural, como hedger, normalmente venderia contratos futuros ou compraria opções de venda. No entanto, como seu preço já estaria fixado através da CPR, uma das alternativas para se beneficiar de elevações de preço seria ingressar no mercado em situação oposta à do hedging de venda. Comprando contratos futuros receberia ajustes se o preço se elevasse, enquanto ao adquirir opções de compra poderia exercer o direito ao preço de exercício, revendendo o produto a preço de mercado (mais alto), e apropriando-se do diferencial positivo.
} 
futuros e apenas 3 em opções, depara-se com o seguinte quadro: a) os produtores ficaram contentes com os preços fixados vis-à-vis seus custos de produção e, eventualmente, os preços históricos do café; b) não acreditavam em elevações de preços; ou c) não tinham acesso fácil às operações, seja pela maior dificuldade em se montar estratégias desse tipo, seja porque o mercado não tem liquidez (especialmente o mercado de opções).

Nas duas safras consideradas (96/97 e 97/98) os preços foram favoráveis às operações de CPR e, certamente por isso, os produtores, de um modo geral, mostraramse satisfeitos com o título e tiveram a sensação de que ganharam dinheiro ao incorporálo em suas estratégias de captação de recursos e de comercialização da produção. No entanto, caso os preços tivessem se elevado de forma razoável, os produtores poderiam ter-se manifestado de forma completamente diferente.

Para a possibilidade de elevação de preços há espaço para o surgimento de profissionais que montem estratégias visando a apropriação desses ganhos e há espaço, também, para a atuação de entidades que aproximem os produtores desses mecanismos de apoio à comercialização.

\subsection{A opinião livre dos produtores}

Tentar aferir a realidade que perpassa o ambiente negocial a partir de questões fechadas se torna mais fácil do ponto de vista da tabulação e interpretação dos dados. Perde-se, contudo, uma riqueza de informações que podem emanar da experiência e da realidade de cada produtor.

Pensando na possibilidade de enriquecimento do trabalho, colocou-se no questionário uma pergunta aberta onde se buscava avaliar, na opinião do produtor, o que faltava para que a CPR se constituísse em um título que melhor pudesse auxiliá-lo em suas necessidades de obtenção de recursos, comercialização da produção e hedging. 
$\mathrm{Na}$ questão aberta as respostas foram reclamativas ou propositivas. Em todo caso, a análise (pelos participantes do mercado) das questões levantadas poderá propiciar o aperfeiçoamento do título ou de sua forma de colocação, permitindo a que os vendedores e compradores melhor se beneficiem dessa modalidade de comercialização.

Tabela 14. CPR: Críticas/sugestões

\begin{tabular}{|c|c|c|c|}
\hline MANIFESTAÇÃO DO PRODUTOR & $\begin{array}{l}\text { CERRADO } \\
\text { MINEIRO }\end{array}$ & $\begin{array}{l}\text { DEMAIS } \\
\text { REGIÕES }\end{array}$ & Total \\
\hline \multicolumn{4}{|l|}{ Classificacão/preparacão do produto: } \\
\hline - $\quad$ rigor na classificação/padronização & 10 & 20 & 30 \\
\hline - $\quad$ aceitação do produto com ágios/deságios & 4 & 5 & 9 \\
\hline - $\quad$ adoção de padrão safra/região & 2 & 11 & 13 \\
\hline - $\quad$ maior envolvimento da cooperativa & 1 & 7 & 8 \\
\hline - $\quad$ definição/clareza de critérios (transparência) & 4 & - & 4 \\
\hline - $\quad$ padrão exigido muito alto & 1 & 1 & 2 \\
\hline - falta de profissionalismo/honestidade do mercado & 1 & 1 & 2 \\
\hline - $\quad$ recebimento de café bica corrida & 1 & 2 & 3 \\
\hline - $\quad$ representante dos produtores na arbitragem & 1 & 1 & 2 \\
\hline \multicolumn{4}{|l|}{ Aspectos inerentes à formalização da cédula: } \\
\hline $\begin{array}{l}\text { vistoria para previsão de safra (demorada/conser- } \\
\text { vadora) }\end{array}$ & 3 & 3 & 6 \\
\hline - $\quad$ excesso de garantias exigidas (hipoteca) & 3 & 14 & 17 \\
\hline - burocracia/demora (banco/registro de imóveis) & 10 & 20 & 30 \\
\hline - $\quad$ necessidade de flexibilizar normas/procedimentos & 4 & 14 & 18 \\
\hline $\begin{array}{l}\text { - } \quad \text { existência de CPR de acordo com padrão regio- } \\
\text { nal/hábitos de comercialização }\end{array}$ & 1 & 11 & 12 \\
\hline - permitir negócios de balcão & 1 & 2 & 3 \\
\hline - $\quad$ lotes menores (ingresso pequeno produtor) & - & 4 & 4 \\
\hline \multicolumn{4}{|l|}{ Aspectos inerentes ao custo } \\
\hline - taxa de aval alta & 4 & 5 & 9 \\
\hline - $\quad$ deságio/custo global altos & 10 & 3 & 13 \\
\hline - armazenamento/beneficiamento/preparo & 3 & 3 & 6 \\
\hline - $\quad$ taxas muito altas nos registros de imóveis & 4 & 6 & 10 \\
\hline \multicolumn{4}{|l|}{ Entrega } \\
\hline $\begin{array}{l}\text { - ampliação da rede de armazéns (mais próximos; } \\
\text { no município; cooperativa) }\end{array}$ & 9 & 17 & 26 \\
\hline - $\quad$ menor exigência/maior agilidade & 5 & 3 & 8 \\
\hline - possibilitar entrega no imóvel & 2 & - & 2 \\
\hline \multicolumn{4}{|l|}{ Aspectos gerais } \\
\hline - possibilitar seguro contra fenômenos adversos & 1 & 1 & 2 \\
\hline $\begin{array}{l}\text { - desenvolver/propiciar acesso a mecanismos de } \\
\text { apropriação de elevação de preços } \\
\text { - } \\
\text { ampliar/melhorar a divulgacão da CPR inclusive }\end{array}$ & 2 & 7 & 9 \\
\hline suas regras & 1 & 11 & 12 \\
\hline possibilitar recompra & - & 3 & 3 \\
\hline
\end{tabular}

Fonte: dados da pesquisa. 
As queixas e sugestões que tiveram mais de um assinalamento foram consolidadas nos seguintes cinco grupos (ver Tabela 14): a) classificação/preparação do produto, com 73 assinalamentos; b) aspectos inerentes à formalização do título, com 90; c) aspectos que envolvem o custo de emissão/registro, com 38; d) questões relativas à entrega do produto, com 36; e e) aspectos gerais, com 26 assinalamentos.

No primeiro grupo, o item que mais se destacou foi aquele considerado como de rigor excessivo na classificação/padronização ${ }^{71}$ do produto. Nos demais itens deste grupamento, os que mais se destacaram dizem respeito a alternativas para equilibrar o assunto, quais sejam: adoção de ágios ou deságios para ajustamento do produto colhido àquele previsto no contrato-padrão; adoção de padrão que seja pertinente à qualidade do café colhido em cada região ou safra (quer de qualidade superior ou inferior); e maior envolvimento das cooperativas na preparação do café, como responsável pela entrega, como classificadora ou, ainda, como representante dos produtores no processo de arbitragem.

No segundo grupo, as queixas dizem respeito aos aspectos burocráticos que emolduram o processo de obtenção do aval bancário. Assim é que a vistoria de previsão de safra para definição dos parâmetros negociais foi considerada demorada e/ou conservadora em 6 oportunidades, enquanto o excesso de garantias exigidas e a demora na conclusão da operação foram objeto de 47 assinalamentos.

Do ponto de vista do aprimoramento do instrumento, foram feitos 18 registros no quesito que sugere a flexibilização das normas e procedimentos, com vistas à imprimir maior tempestividade ao processo, principalmente no que diz respeito à possibilidade de aproveitamento de momentos favoráveis de preços. Ainda com respeito ao aprimoramento do título, 12 produtores sugeriram a adoção de CPRs moldadas de acordo com o padrão e hábitos regionais de comercialização.

\footnotetext{
${ }^{71}$ Uma das queixas é de que o rigor na classificação deixa o produtor vulnerável, tendo seu produto recusado ou sendo forçado a aceitar deságios.
} 
No aspecto custo, a pesquisa surpreende. O senso comum, muito presente na mídia e em conversas informais, é de que os negócios com CPR são inibidos pelo alto custo do aval. No entanto, apenas 9 produtores (4,9\% do total) consideraram essa realidade. $\mathrm{O}$ custo de aval é superado pelas reclamações quanto aos elevados custos de registro das CPR nos Registros de Imóveis, para validade das garantias. O principal item deste segmento é aquele que considera os custos globais, incluindo o deságio, muito altos.

Com relação ao item "entrega", o que se destaca é a sugestão para que seja ampliada a rede armazenadora, de forma a que os armazéns se situem mais próximos do imóvel produtor. É de se registrar, também, a solicitação dos produtores para que as cooperativas sejam admitidas como armazenadoras.

Por fim, destacam-se nos "aspectos gerais" os itens relativos à possibilidade de apropriação de eventuais altas de preços e que diz respeito à necessidade de maior divulgação do título, inclusive de suas regras. Talvez uma melhor divulgação das regras e a constância na negociação de CPR possam minorar as críticas quanto à classificação do produto. Esta questão talvez possa ser amenizada, porém a existência de tantas queixas sugere que esse item realmente deve apresentar componentes problemáticos.

Além dos aspectos contidos na Tabela 14, foram assinalados alguns pontos interessantes, como os seguintes: que o leilão de venda de CPR seja interligado às bolsas internacionais; que seja propiciado seguro de carga (transporte até o armazém); que haja pré-amostra antes da entrega; que seja estipulado quantidade aceitável de defeitos na CPR (tipo 6, até 80 defeitos, por exemplo); que haja melhoria no relacionamento produtor/BM\&F; que seja adotado bônus de fiança em operações junto à BM\&F, devido à tradição/idoneidade; que haja maior agilidade na liberação do crédito pós leilão; que sejam admitidas CPRs de prazos superiores a uma safra; que os critérios de previsão de safra sejam apurados; que se admita a liquidação financeira; que se pugne por maior 
liquidez, como forma de reduzir o deságio; que se admita a vinculação de mais de um produtor por lote (acesso aos pequenos produtores); que haja liquidez no mercado de opções e, finalmente, que dívidas antigas possam ser repactuadas com CPR.

\subsection{Considerações finais sobre o capítulo}

Embora a motivação inicial para o surgimento da CPR tenha sido dotar o setor rural de um instrumento que permitisse o financiamento privado das safras, desafogando a pressão sobre o crédito rural institucional, com o seu lançamento não só os agentes do agribusiness se interessaram pelo título, mas, também, segmentos do mercado financeiro que, ao buscarem alternativas de aplicação para seus recursos, acabam fornecendo o funding necessário ao financiamento das atividades rurais a taxas mais atrativas do que aquelas cobradas pelo sistema financeiro em operações de capital de giro.

Quando o comprador de CPR pertence à cadeia do agribusiness a operação entre esses agentes se configura como uma transação a termo clássica. $O$ vendedor da $C P R$ assume o compromisso de entregar o produto físico no qual o comprador está efetivamente interessado. Não havendo inadimplência por parte do vendedor, há sucesso no desfecho da transação.

No entanto, quando o comprador é apenas um detentor de poupança e procura alternativas de investimento, certamente não haverá interesse no produto físico. Por isso a existência de um mercado secundário seria interessante e, também, é por essa razão que se estuda no âmbito da BM\&F a adoção de uma CPR com liquidação financeira. Na medida em que cresça a demanda pelo título há a tendência de o custo de sua emissão se tornar mais atrativo para o produtor rural.

Como se pode perceber ao longo do texto, os produtores que utilizaram a CPR consideram que esse instrumento veio preencher uma lacuna existente no mercado, não só quanto ao aspecto "financiamento", mas também quanto ao aspecto proteção contra 
quedas de preço. Durante a realização das entrevistas foi muito comum ouvir-se considerações positivas a respeito do título, principalmente considerando ser uma das únicas alternativas à disposição dos produtores de maior porte.

Além disso, percebeu-se claramente que a utilização dos mercados futuros como instrumento de fixação de preço, por parte dos produtores, cresceu a partir da experiência com a CPR, além do que, muitos dos títulos emitidos na safra 98/99 se destinaram a lastrear operações realizadas junto à $B M \& F$. 


\section{CPR: FINANCIAMENTO E HEDGING}

\subsection{A CPR como instrumento de financiamento}

Como visto nos tópicos anteriores, a CPR desempenha dois papéis principais. Ao mesmo tempo que se caracteriza como um instrumento de captação de recursos, se constitui, também, em instrumento de proteção contra movimentos de quedas nos preços.

$\mathrm{Na}$ atividade rural, assim como em qualquer outra atividade econômica, o crédito exerce um papel significante, uma vez que apresenta a capacidade de substituir e/ou complementar os recursos próprios. Na busca de capitais de terceiros para a satisfação das necessidades de tratos culturais e colheita há, no entanto, limitações técnicas e financeiras representadas pelas características peculiares da atividade rural, com altos riscos de preços e de produção (além dos percalços naturais, a atividade é tomadora de preços).

Como se viu anteriormente, o Estado era o principal alocador de recursos ao campo, situação que se deteriorou com a crise fiscal e que esteve no âmago da criação da CPR, cujo principal motivador teria sido a possibilidade de permitir o financiamento privado das atividades rurais.

As práticas existentes apresentavam dois complicadores principais. Para o tomador de recursos, os altos deságios praticados em operações do tipo "troca-troca" ou de venda de safra pendente. Para o alocador, o risco de inadimplemento por parte do produtor. 
A CPR, quando avalizada por uma instituição financeira, praticamente elimina o risco de default na entrega do produto, ao passo que, como instrumento de financiamento apresentaria uma situação ideal se suas taxas se aproximassem daquelas praticadas no crédito rural oficial ${ }^{72}$. A situação mais desfavorável seria aquela em que a taxa de juros, embutida nas operações de CPR, se aproximasse ou até mesmo superasse as taxas vigentes para operações de capital de giro.

Esta seção tem o intuito de - baseado nos dados relativos às CPR de café das safras $96 / 97$ e $97 / 98$ - avaliar se esse título cumpriu adequadamente seu papel de instrumento de captação de recursos.

Ressalta-se contudo que, embora segmentado para efeito analítico, o papel da CPR como instrumento de financiamento não deve ser visto de forma isolada, mas sim, contemplando seu papel de proteção de preços (assunto da próxima seção) e como elemento instrumentalizador da própria produção em $\mathrm{si}^{73}$.

Para efeito comparativo, a Tabela 15 apresenta os dados relativos ao prazo de vigência dos títulos; valor líquido, por saca, obtido com a venda através de CPR; preço futuro (na emissão do título) do contrato mais próximo ao vencimento da CPR; deságio praticado; custo financeiro total para o tomador dos recursos $\left(\mathrm{i}_{\mathrm{cpr}}\right)$; taxa over anual e taxa anual de capital de giro.

Os dados referidos são apresentados em valores médios por mês de emissão das CPR (com os respectivos desvios-padrão) e segmentados em três regiões ${ }^{74}$ produtoras:

\footnotetext{
${ }^{72}$ Há um reconhecimento geral de que o setor rural necessita de taxas diferenciadas em relação aos demais setores da economia, seja em função dos riscos que incorpora, seja por ser uma atividade tomadora de preços, seja por se inserir numa realidade internacional de altos subsidios e protecionismo.

${ }^{73}$ Deve-se lembrar que, se o produtor não dispuser de recursos, poderá ter sua produção diminuida pela ausência ou deficiência nos tratos culturais. Qual o valor econômico atribuído a essas perdas? Evitar as perdas compensaria a assunção de uma taxa de juros mais elevada? As respostas poderiam ser obtidas em pesquisas adicionais.

${ }^{74}$ Por apresentar apenas $10 \mathrm{CPR}$, não foram considerados os dados relativos ao Paraná.
} 
Estado de São Paulo; cerrado mineiro e sul de Minas. A segmentação adotada fornece 38 observações.

Tabela 15. A CPR como instrumento de financiamento

\begin{tabular}{|c|c|c|c|c|c|c|c|c|c|}
\hline $\begin{array}{l}\text { mês/ } \\
\text { ano }\end{array}$ & região & est. & $\begin{array}{c}\text { prazo } \\
\text { dias }\end{array}$ & $\begin{array}{r}\text { vr./saca } \\
\text { R\$ }\end{array}$ & $\begin{array}{r}\text { Pfut } \\
\text { emissão } \\
R \$ \\
\end{array}$ & deságio & $\begin{array}{r}\text { icpr } \\
\text { anual }\end{array}$ & $\begin{array}{r}\text { taxa over } \\
\text { anual }\end{array}$ & $\begin{array}{r}\text { taxa } \\
\text { cap.giro } \\
\text { anual } \\
\end{array}$ \\
\hline Nov/95 & são paulo & $\begin{array}{l}\mathbf{m} \\
\mathrm{dp}\end{array}$ & $\begin{array}{r}285 \\
0\end{array}$ & $\begin{array}{r}95.00 \\
0\end{array}$ & $\begin{array}{r}116.77 \\
0\end{array}$ & $\begin{array}{r}18.64 \\
0\end{array}$ & $\begin{array}{r}29.77 \\
0\end{array}$ & $\begin{array}{r}39.45 \\
0\end{array}$ & $\begin{array}{r}73.80 \\
0\end{array}$ \\
\hline \multirow[t]{2}{*}{ Jan/96 } & são paulo & $\begin{array}{l}m \\
d p\end{array}$ & $\begin{array}{r}220 \\
0\end{array}$ & $\begin{array}{r}90.00 \\
0\end{array}$ & $\begin{array}{r}120.22 \\
0\end{array}$ & $\begin{array}{r}25.14 \\
0\end{array}$ & $\begin{array}{r}60.60 \\
0\end{array}$ & $\begin{array}{r}34.02 \\
0\end{array}$ & $\begin{array}{r}55.20 \\
0\end{array}$ \\
\hline & cerrado MG & $\begin{array}{l}m \\
d p\end{array}$ & $\begin{array}{r}218 \\
5.37\end{array}$ & $\begin{array}{r}89.5 \\
4.75\end{array}$ & $\begin{array}{r}119.85 \\
6.13\end{array}$ & $\begin{array}{r}25.29 \\
3.39\end{array}$ & $\begin{array}{r}62.72 \\
13.46\end{array}$ & $\begin{array}{r}35.25 \\
0.76\end{array}$ & $\begin{array}{r}56.81 \\
1.84\end{array}$ \\
\hline \multirow[t]{2}{*}{ Fev/96 } & são paulo & $\begin{array}{c}m \\
d p\end{array}$ & $\begin{array}{l}190 \\
24.58\end{array}$ & $\begin{array}{r}108.66 \\
2.09\end{array}$ & $\begin{array}{r}129.87 \\
5.74\end{array}$ & $\begin{array}{r}16.17 \\
4.35\end{array}$ & $\begin{array}{r}44.10 \\
21.97\end{array}$ & $\begin{array}{r}32.55 \\
0.05\end{array}$ & $\begin{array}{r}52.11 \\
1.88\end{array}$ \\
\hline & cerrado MG & $\begin{array}{l}m \\
d p\end{array}$ & $\begin{array}{l}191 \\
15.77\end{array}$ & $\begin{array}{r}108.85 \\
7.34\end{array}$ & $\begin{array}{r}128.61 \\
3.03\end{array}$ & $\begin{array}{r}15.38 \\
5.14\end{array}$ & $\begin{array}{r}37.93 \\
15.69\end{array}$ & $\begin{array}{r}33.59 \\
1.14\end{array}$ & $\begin{array}{r}48.85 \\
2.35\end{array}$ \\
\hline \multirow[t]{3}{*}{ Mar/96 } & são paulo & $\begin{array}{l}m \\
d p\end{array}$ & $\begin{array}{l}137 \\
26.04\end{array}$ & $\begin{array}{r}108.87 \\
1.17\end{array}$ & $\begin{array}{r}128.07 \\
2.44\end{array}$ & $\begin{array}{r}14.97 \\
1.18\end{array}$ & $\begin{array}{r}57.12 \\
20.96\end{array}$ & $\begin{array}{r}28.59 \\
0.06\end{array}$ & $\begin{array}{r}46.52 \\
0.14\end{array}$ \\
\hline & cerrado MG & $\underset{d p}{m}$ & $\begin{array}{r}157 \\
1.89\end{array}$ & $\begin{array}{r}108 \\
0\end{array}$ & $\begin{array}{r}125.74 \\
1.02\end{array}$ & $\begin{array}{r}14.11 \\
0.70\end{array}$ & $\begin{array}{r}41.80 \\
2.26\end{array}$ & $\begin{array}{r}28.54 \\
0\end{array}$ & $\begin{array}{r}47.43 \\
2.07\end{array}$ \\
\hline & sul MG & $\begin{array}{l}m \\
d p\end{array}$ & $\begin{array}{l}151 \\
13.92\end{array}$ & $\begin{array}{r}109.59 \\
3.19\end{array}$ & $\begin{array}{r}125.67 \\
279\end{array}$ & $\begin{array}{r}12.80 \\
1.04\end{array}$ & $\begin{array}{r}38.95 \\
3.52\end{array}$ & $\begin{array}{r}28.55 \\
0.03\end{array}$ & $\begin{array}{r}49.21 \\
1.99\end{array}$ \\
\hline \multirow[t]{2}{*}{ Abr/96 } & cerrado MG & $\underset{d p}{m}$ & $\begin{array}{r}139 \\
8.74\end{array}$ & $\begin{array}{r}110.93 \\
2.36\end{array}$ & $\begin{array}{r}123.23 \\
2.76\end{array}$ & $\begin{array}{r}9.96 \\
2.09\end{array}$ & $\begin{array}{r}31.62 \\
8.38\end{array}$ & $\begin{array}{r}27.80 \\
0.87\end{array}$ & $\begin{array}{r}58.55 \\
1.07\end{array}$ \\
\hline & sul MG & $\begin{array}{l}m \\
d p\end{array}$ & $\begin{array}{l}149 \\
10.29\end{array}$ & $\begin{array}{r}109.20 \\
2.35\end{array}$ & $\begin{array}{r}122.84 \\
3.96\end{array}$ & $\begin{array}{r}11.07 \\
1.72\end{array}$ & $\begin{array}{r}33.57 \\
8.85\end{array}$ & $\begin{array}{r}27.16 \\
0.41\end{array}$ & $\begin{array}{r}58.80 \\
\quad 0.90\end{array}$ \\
\hline \multirow[t]{3}{*}{ Mai/96 } & são paulo & $\begin{array}{l}m \\
d p\end{array}$ & $\begin{array}{r}93 \\
30.95\end{array}$ & $\begin{array}{r}122.75 \\
3.03\end{array}$ & $\begin{array}{r}131.57 \\
2.37\end{array}$ & $\begin{array}{r}6.68 \\
2.70\end{array}$ & $\begin{array}{r}34.15 \\
15.87\end{array}$ & $\begin{array}{r}25.30 \\
0.12\end{array}$ & $\begin{array}{r}49.37 \\
1.47\end{array}$ \\
\hline & cerrado MG & $\underset{d p}{m}$ & $\begin{array}{r}111 \\
3.58\end{array}$ & $\begin{array}{r}116.15 \\
3.31\end{array}$ & $\begin{array}{r}132.40 \\
1.53\end{array}$ & $\begin{array}{r}12.28 \\
1.65\end{array}$ & $\begin{array}{r}53.28 \\
7.78\end{array}$ & $\begin{array}{r}25.22 \\
0.05\end{array}$ & $\begin{array}{r}53.19 \\
3.60\end{array}$ \\
\hline & sul MG & $\underset{d p}{m}$ & $\begin{array}{r}111 \\
5.12\end{array}$ & $\begin{array}{r}117.72 \\
4.37\end{array}$ & $\begin{array}{r}132.34 \\
1.03\end{array}$ & $\begin{array}{r}11.05 \\
3.05\end{array}$ & $\begin{array}{r}47.03 \\
15.77\end{array}$ & $\begin{array}{r}25.26 \\
0.10\end{array}$ & $\begin{array}{r}52.87 \\
3.43\end{array}$ \\
\hline \multirow[t]{2}{*}{ Jun/96 } & cerrado MG & $\underset{d p}{m}$ & 84 & 117.01 & 126.66 & 7.62 & 40.44 & 27.23 & 47.04 \\
\hline & sul MG & $\begin{array}{l}m \\
d p\end{array}$ & $\begin{array}{l}86 \\
0.58\end{array}$ & $\begin{array}{r}113.15 \\
1.62\end{array}$ & $\begin{array}{r}125.84 \\
0\end{array}$ & $\begin{array}{r}10.08 \\
1.29\end{array}$ & $\begin{array}{r}56.46 \\
8.80\end{array}$ & $\begin{array}{r}26.36 \\
0\end{array}$ & $\begin{array}{r}46.68 \\
0.13\end{array}$ \\
\hline Jul/96 & sul MG & $\begin{array}{l}\mathbf{m} \\
\mathrm{dp}\end{array}$ & 59 & 108.75 & 116.65 & 6.77 & 53.37 & 24.70 & 44.70 \\
\hline Out/96 & sul MG & $\begin{array}{l}\mathbf{m} \\
\mathrm{dp}\end{array}$ & $\begin{array}{r}277 \\
0\end{array}$ & $\begin{array}{r}96.73 \\
0.38\end{array}$ & $\begin{array}{r}121.16 \\
0\end{array}$ & $\begin{array}{r}20.16 \\
0.31\end{array}$ & $\begin{array}{r}34.00 \\
0.68\end{array}$ & $\begin{array}{r}26.48 \\
0\end{array}$ & $\begin{array}{r}44.41 \\
0\end{array}$ \\
\hline Nov/96 & são paulo & $\begin{array}{l}m \\
d p\end{array}$ & 239 & 101.10 & 126.70 & 20.21 & 40.50 & 23.80 & 41.44 \\
\hline
\end{tabular}


Tabela 15. A CPR como instrumento de financiamento

\begin{tabular}{|c|c|c|c|c|c|c|c|c|c|}
\hline $\begin{array}{l}\text { mês/ } \\
\text { ano }\end{array}$ & região & est. & $\begin{array}{r}\text { prazo } \\
\text { dias }\end{array}$ & $\begin{array}{r}\text { vr./saca } \\
\text { R\$ }\end{array}$ & $\begin{array}{r}\text { Pfut } \\
\text { emissão } \\
\text { R\$ }\end{array}$ & deságio & $\begin{array}{l}\text { icpr } \\
\text { anual }\end{array}$ & $\begin{array}{r}\text { taxa over } \\
\text { anual }\end{array}$ & $\begin{array}{r}\text { taxa } \\
\text { cap.giro } \\
\text { anual } \\
\end{array}$ \\
\hline \multirow[t]{3}{*}{ Dez/96 } & são paulo & $\begin{array}{l}m \\
d p\end{array}$ & 273 & 101.10 & 122.93 & 17.76 & 29.40 & 22.43 & 43.10 \\
\hline & cerrado MG & $\begin{array}{l}m \\
d p\end{array}$ & $\begin{array}{r}257 \\
9.90\end{array}$ & $\begin{array}{r}105.78 \\
6.26\end{array}$ & $\begin{array}{r}128.49 \\
7.87\end{array}$ & $\begin{array}{r}17.67 \\
0.17\end{array}$ & $\begin{array}{r}31.36 \\
1.76\end{array}$ & $\begin{array}{r}22.82 \\
0.56\end{array}$ & $\begin{array}{r}43.90 \\
1.13\end{array}$ \\
\hline & sul MG & $\begin{array}{l}m \\
d p\end{array}$ & $\begin{array}{r}263 \\
4.04\end{array}$ & $\begin{array}{r}111.48 \\
14.02\end{array}$ & $\begin{array}{r}132.28 \\
0\end{array}$ & $\begin{array}{r}15.73 \\
10.60\end{array}$ & $\begin{array}{r}28.78 \\
19.38\end{array}$ & $\begin{array}{r}23.52 \\
0\end{array}$ & $\begin{array}{r}41.30 \\
0.20\end{array}$ \\
\hline \multirow[t]{3}{*}{ Jan/97 } & são paulo & $\begin{array}{l}m \\
d p\end{array}$ & $\begin{array}{l}215 \\
25.16\end{array}$ & $\begin{array}{r}129.22 \\
8.00\end{array}$ & $\begin{array}{r}152.18 \\
5.87\end{array}$ & $\begin{array}{r}15.12 \\
3.29\end{array}$ & $\begin{array}{r}32.81 \\
12.57\end{array}$ & $\begin{array}{r}22.42 \\
0.48\end{array}$ & $\begin{array}{r}49.08 \\
0.73\end{array}$ \\
\hline & cerrado MG & $\begin{array}{l}m \\
d p\end{array}$ & $\begin{array}{l}223 \\
14.76\end{array}$ & $\begin{array}{r}128.18 \\
11.07\end{array}$ & $\begin{array}{r}152.29 \\
7.23\end{array}$ & $\begin{array}{r}15.88 \\
5.36\end{array}$ & $\begin{array}{r}33.29 \\
12.32\end{array}$ & $\begin{array}{r}22.22 \\
0.42\end{array}$ & $\begin{array}{r}49.09 \\
0.85\end{array}$ \\
\hline & sul MG & $\begin{array}{l}\mathbf{m} \\
\mathrm{dp}\end{array}$ & $\begin{array}{l}238 \\
14.61\end{array}$ & $\begin{array}{r}128.59 \\
7.42\end{array}$ & $\begin{array}{r}149.67 \\
7.58\end{array}$ & $\begin{array}{r}14.10 \\
1.76\end{array}$ & $\begin{array}{r}25.89 \\
3.68\end{array}$ & $\begin{array}{r}22.96 \\
1.75\end{array}$ & $\begin{array}{r}48.85 \\
0.81\end{array}$ \\
\hline \multirow[t]{3}{*}{ Fev/97 } & são paulo & $\begin{array}{l}m \\
d p\end{array}$ & $\begin{array}{l}185 \\
32.36\end{array}$ & $\begin{array}{r}164.92 \\
10.93\end{array}$ & $\begin{array}{r}192.56 \\
10.99\end{array}$ & $\begin{array}{r}14.34 \\
3.53\end{array}$ & $\begin{array}{r}37.43 \\
14.97\end{array}$ & $\begin{array}{r}23.13 \\
0.77\end{array}$ & $\begin{array}{r}45.99 \\
2.04\end{array}$ \\
\hline & cerrado MG & $\begin{array}{l}m \\
d p\end{array}$ & $\begin{array}{l}193 \\
14.93\end{array}$ & $\begin{array}{r}156.54 \\
7.83\end{array}$ & $\begin{array}{r}187.07 \\
6.52\end{array}$ & $\begin{array}{r}16.30 \\
3.42\end{array}$ & $\begin{array}{r}40.01 \\
10.73\end{array}$ & $\begin{array}{r}23.57 \\
0.26\end{array}$ & $\begin{array}{r}46.66 \\
1.97\end{array}$ \\
\hline & sul MG & $\begin{array}{c}m \\
d p\end{array}$ & $\begin{array}{r}199 \\
21.3\end{array}$ & $\begin{array}{r}148.84 \\
12.56\end{array}$ & $\begin{array}{r}180.24 \\
12.68\end{array}$ & $\begin{array}{r}17.41 \\
3.97\end{array}$ & $\begin{array}{r}42.67 \\
13.14\end{array}$ & $\begin{array}{r}23.65 \\
0.47\end{array}$ & $\begin{array}{r}47.97 \\
1.74\end{array}$ \\
\hline \multirow[t]{3}{*}{ Mar/97 } & são paulo & $\begin{array}{l}m \\
d p\end{array}$ & $\begin{array}{l}153 \\
23.92\end{array}$ & $\begin{array}{r}179.66 \\
13.65\end{array}$ & $\begin{array}{r}198.75 \\
12.97\end{array}$ & $\begin{array}{r}9.39 \\
\quad 7.49\end{array}$ & $\begin{array}{r}26.90 \\
20.93\end{array}$ & $\begin{array}{r}20.58 \\
0.68\end{array}$ & $\begin{array}{r}45.66 \\
1.48\end{array}$ \\
\hline & cerrado MG & $\underset{d p}{m}$ & $\begin{array}{l}174 \\
12.88\end{array}$ & $\begin{array}{r}177.29 \\
9.73\end{array}$ & $\begin{array}{r}208.78 \\
9.96\end{array}$ & $\begin{array}{r}14.99 \\
4.57\end{array}$ & $\begin{array}{r}40.55 \\
13.99\end{array}$ & $\begin{array}{r}20.62 \\
0.63\end{array}$ & $\begin{array}{r}45.72 \\
1.46\end{array}$ \\
\hline & sul MG & $\begin{array}{c}m \\
d p\end{array}$ & $\begin{array}{l}168 \\
20.58\end{array}$ & $\begin{array}{r}173.20 \\
10.50\end{array}$ & $\begin{array}{r}205.77 \\
13.36\end{array}$ & $\begin{array}{r}15.68 \\
4.66\end{array}$ & $\begin{array}{r}45.86 \\
16.81\end{array}$ & $\begin{array}{r}20.57 \\
0.62\end{array}$ & $\begin{array}{r}45.67 \\
1.45\end{array}$ \\
\hline \multirow[t]{3}{*}{ Abr/97 } & são paulo & $\begin{array}{l}m \\
d p\end{array}$ & $\begin{array}{l}113 \\
30.67\end{array}$ & $\begin{array}{r}181.83 \\
8.86\end{array}$ & $\begin{array}{r}207.65 \\
8.57\end{array}$ & $\begin{array}{r}12.44 \\
2.18\end{array}$ & $\begin{array}{r}56.89 \\
17.79\end{array}$ & $\begin{array}{r}22.07 \\
0.82\end{array}$ & $\begin{array}{r}41.22 \\
0.51\end{array}$ \\
\hline & cerrado MG & $\underset{d p}{m}$ & $\begin{array}{l}135 \\
20.53\end{array}$ & $\begin{array}{r}177.55 \\
9.32\end{array}$ & $\begin{array}{r}201.71 \\
6.81\end{array}$ & $\begin{array}{r}11.96 \\
4.01\end{array}$ & $\begin{array}{r}42.37 \\
16.80\end{array}$ & $\begin{array}{r}21.86 \\
0.76\end{array}$ & $\begin{array}{r}41.09 \\
0.58\end{array}$ \\
\hline & sul MG & $\begin{array}{c}m \\
d p\end{array}$ & $\begin{array}{l}134 \\
20.74\end{array}$ & $\begin{array}{r}177.38 \\
8.18\end{array}$ & $\begin{array}{r}202.70 \\
7.44\end{array}$ & $\begin{array}{r}12.46 \\
3.50\end{array}$ & $\begin{array}{r}45.67 \\
\quad 17.42\end{array}$ & $\begin{array}{r}22.01 \\
0.79\end{array}$ & $\begin{array}{r}41.24 \\
0.43\end{array}$ \\
\hline \multirow[t]{3}{*}{ Mai/97 } & são paulo & $\underset{d p}{m}$ & $\begin{array}{l}101 \\
25.91\end{array}$ & $\begin{array}{r}204.19 \\
15.61\end{array}$ & $\begin{array}{r}239.99 \\
20.55\end{array}$ & $\begin{array}{r}14.76 \\
4.14\end{array}$ & $\begin{array}{r}84.47 \\
35.53\end{array}$ & $\begin{array}{r}20.07 \\
0.14\end{array}$ & $\begin{array}{r}43.00 \\
0.74\end{array}$ \\
\hline & cerrado MG & $\begin{array}{l}m \\
d p\end{array}$ & $\begin{array}{l}101 \\
24.66\end{array}$ & $\begin{array}{r}208.21 \\
20.28\end{array}$ & $\begin{array}{r}243.06 \\
21.02\end{array}$ & $\begin{array}{r}14.34 \\
4.21\end{array}$ & $\begin{array}{r}81.83 \\
44.91\end{array}$ & $\begin{array}{r}20.09 \\
0.13\end{array}$ & $\begin{array}{r}43.11 \\
0.51\end{array}$ \\
\hline & sul MG & $\begin{array}{l}m \\
d p\end{array}$ & $\begin{array}{l}110 \\
17.79\end{array}$ & $\begin{array}{r}198.88 \\
14.55\end{array}$ & $\begin{array}{r}239.37 \\
20.00\end{array}$ & $\begin{array}{r}16.77 \\
3.65\end{array}$ & $\begin{array}{r}91.35 \\
44.16\end{array}$ & $\begin{array}{r}20.01 \\
0.29\end{array}$ & $\begin{array}{r}43.11 \\
0.44\end{array}$ \\
\hline \multirow[t]{2}{*}{ Jun/97 } & cerrado MG & $\begin{array}{l}m \\
d p\end{array}$ & $\begin{array}{r}74 \\
29.58\end{array}$ & $\begin{array}{r}205.95 \\
92.76\end{array}$ & $\begin{array}{r}229.09 \\
104.43\end{array}$ & $\begin{array}{r}9.08 \\
6.07\end{array}$ & $\begin{array}{r}65.02 \\
51.17\end{array}$ & $\begin{array}{r}16.99 \\
8.28\end{array}$ & $\begin{array}{r}36.35 \\
17.57\end{array}$ \\
\hline & sul MG & $\begin{array}{l}m \\
d p\end{array}$ & $\begin{array}{l}87 \\
8.95\end{array}$ & $\begin{array}{r}244.70 \\
16.56\end{array}$ & $\begin{array}{r}251.28 \\
17.21\end{array}$ & $\begin{array}{r}2.48 \\
5.44\end{array}$ & $\begin{array}{r}14.28 \\
25.93\end{array}$ & $\begin{array}{r}21.08 \\
0.23\end{array}$ & $\begin{array}{r}43.14 \\
0.09\end{array}$ \\
\hline
\end{tabular}

Fonte: dados da pesquisa. 
A taxa $i_{c p r}$ foi obtida considerando-se o preço futuro BM\&F, em reais, como valor futuro; o preço da CPR, em reais (valor real de venda), como valor presente e, como prazo, o número médio de dias com os quais os títulos foram emitidos. A taxa diária resultante foi anualizada, fornecendo a taxa de juros praticada no "financiamento". As taxas CDI-over, obtidas diariamente, foram anualizadas, enquanto as taxas de capital de giro $^{75}$, fornecidas originalmente para períodos semanais, foi tornada diária por interpolação linear e, ao fim, anualizada, com base no conceito de taxas equivalentes.

Uma palavra adicional merece ser dita a respeito da taxa CDI-over. Essa é uma taxa de captação, apurada nas transações interbancárias. Além disso, serve como parâmetro nas aplicações em CDB e em fundos. Alguns fundos, chegam a remunerar os cotistas com até $95 \%$ dessa taxa. Dessa forma, obter recursos à essa taxa já seria uma boa alternativa, principalmente se esses recursos têm como destino a viabilização da produção.

Conforme se vê pela análise da Tabela 15, das 38 observações ali contidas, apenas 5 apontam para uma taxa de financiamento $\left(\mathrm{i}_{\mathrm{cpr}}\right.$ ) próxima à taxa CDI-over, portanto a um custo atrativo. Destas 5, duas se situaram em patamar inferior (São Paulo, nov/95 e sul de Minas, jun/97), enquanto as demais a superaram em até 15\% (cerrado mineiro, fev. e abr/96 e sul de Minas, jan/97).

No geral, das 38 observações, em 24 oportunidades $(63,2 \%)$ o custo financeiro para os produtores situou-se em níveis inferiores às taxas de capital de giro. Pode-se dizer que a taxa de capital de giro seria um teto máximo para a obtenção de recursos. $\mathrm{Na}$ média, as 24 observações que se situaram em níveis inferiores a essa taxa, refletem um percentual de $72 \%$ da taxa de capital de giro, ou seja, na média as taxas de financiamento das CPR foram $28 \%$ inferiores às taxas vigentes para capital de giro. Resta saber se esse patamar pode ser considerado bom.

\footnotetext{
${ }^{75}$ Os preços futuros foram fornecidos pela BM\&F, enquanto as taxas CDI-over e de capital de giro foram obtidas na revista Juros \& Moedas, da Agência Dinheiro Vivo.
} 
Para uma atividade comercial ou industrial, as taxas obtidas podem ser consideradas satisfatórias. No entanto, para o setor primário o nível de taxas aferido poderia ser considerado alto, não fossem alguns atenuantes.

O deságio médio do preço das CPR em relação ao preço futuro foi de $13,96 \%$, indicando um descasamento não muito grande em relação a esse número e, considerado o patamar de preços obtido para as CPR (R\$128,41 na média das 24 observações), observa-se uma significativa margem de lucro, quando comparado aos custos de produção. Bacha $(1998$, p.18) apurou um custo de produção de US $\$ 68,95$, na média entre os anos 1996 e 1997, para as regiões de Ribeirão Claro (PR) e Três Pontas (MG), para o sistema de plantio tradicional e de US\$ 48,35 no caso do sistema adensado ${ }^{76}$. Referida margem de lucro estaria a indicar que seria melhor absorver os encargos financeiros observados, do que sujeitar-se a uma produção menor, pela incapacidade de cuidar adequadamente da lavoura.

Além disso, não se sabe qual seria a taxa de juros praticada nas operações de escambo e naquelas de adiantamento por conta de entregas futuras.

Por fim, cabe considerar as taxas que se situaram em patamar superior às taxas de capital de giro. Neste item encontram-se $14(36,8 \%)$ das 38 observações registradas. Nesta categoria percebe-se que 6 observações estão compreendidas no período de emissão das CPR da safra 96/97, distribuídas entre os meses de janeiro, março, maio, junho e julho de 1996. Não há, aparentemente, um elo comum entre as observações, a não ser que 3 foram registradas na fase de tratos culturais e 3 na fase de colheita.

As observações restantes concentraram-se maciçamente nos meses de abril e maio/97, com assinalamentos para todas as três regiões consideradas, enquanto para

\footnotetext{
${ }^{76}$ Os preços citados podem ser utilizados como proxy para as demais regiões produtoras. A taxa de câmbio em todo o periodo considerado variou de $\mathrm{R} \$ 0,9650$ por dólar, a cerca de $\mathrm{R} \$ 1,0761$ por dólar.
} 
março/97 houve um único registro para o sul de Minas e, para junho/97, o registro final, para o cerrado mineiro.

- Nessas observações que superaram a taxa de capital de giro, houve uniformidade em sua distribuição por regiões: 4 para São Paulo; 5 para o sul de Minas e 5 para 0 cerrado mineiro. Por outro lado, dentre as 14 observações, 10 apresentaram deságios de até $15 \%$, percentual razoavelmente aceitável.

Também para essas observações não há um padrão de comportamento uniforme, devendo-se ressaltar que no ano de 97 as taxas mais elevadas concentraram-se no mês de maio, mês que apresentou os preços futuros mais elevados. Aliás, o patamar de preços futuros, sobre os quais foram baseados os preços das CPR eram substancialmente superiores aos custos de produção, oferecendo margem para a atividade suportar taxas de juros mais elevadas.

Se a taxa de capital de giro puder ser considerada como referencial para as taxas de financiamento, pode-se concluir que as taxas de juros para a CPR foram satisfatórias, uma vez que 24 das 38 taxas apuradas ficaram aquém desse referencial, enquanto 3 situaram-se em patamar minimamente superior, totalizando, nesse enfoque, $71 \%$ das CPR emitidas nessa faixa de juros.

\subsection{A CPR como instrumento de hedging}

No capítulo introdutório - visão geral do problema - destacou-se que além do risco de produção, os produtores rurais estão expostos principalmente aos risco de carência de recursos para o plantio/condução das lavouras e aos riscos de preço.

Entre as alternativas existentes para esse último tipo de risco estão os contratos a termo, futuros ou de opções. Nesta seção analisar-se-á o desempenho da CPR como instrumento de hedging, comparando-a com a proteção obtida com a venda de contratos 
futuros. A base para comparação foi propiciada pelo modelo desenvolvido por Nelson (1985), expresso pela equação (17), depois de considerados os devidos ajustes em virtude da situação singular da CPR.

A CPR é negociada em lotes de 100 sacas, equivalendo cada contrato, portanto, a um contrato futuro de café negociado na BM\&F. Assim, o hedging desejado $\left(\mathrm{x}_{\mathrm{p}}\right)$ se iguala ao hedging através de futuros $\left(\mathrm{x}_{\mathrm{f}}\right)$. Além disso, se for considerada a análise unitária $\left(x_{p}=1\right)$, a equação (17) se reduz a:

$$
R_{\text {fit }}-R_{\text {fwd }}=\Delta b+I
$$

Substituindo-se $\Delta \mathrm{b}$ por sua expressão equivalente (ver seção 4.2.2), obtém-se:

$$
R_{\text {fut }}-R_{\text {fwd }}=\left[p\left(t^{*}, t^{*}\right)-p\left(t, t^{*}\right)\right]-\left[f\left(t^{*}, T\right)-f(t, T)+I\right]
$$

No modelo original e na equação acima, $\mathrm{p}\left(\mathrm{t}^{*}, \mathrm{t}^{*}\right)$ refere-se ao preço disponível, pois assume-se que em $t^{*}$ o preço a termo se torna o preço spot, uma vez que tal contrato, nesse período, requer entrega imediata (Nelson, 1985, p.16). Por outro lado, $p\left(t, t^{*}\right)$, que no modelo original representa o preço negociado em $t$, para entrega do produto em $t^{*}$, na equação (21) tem a mesma correspondência, porém de forma ajustada financeiramente. $O$ preço em questão é o preço líquido obtido por saca na venda da CPR (deduzida a taxa de aval), transportado até o vencimento do título ${ }^{77}$ com a incidência de $90 \%$ da taxa CDI-over ou pela taxa mensal de remuneração da caderneta de poupança ${ }^{78}$.

\footnotetext{
${ }^{77}$ Como o preço da CPR sofreu um desconto financeiro quando da negociação do título, não há perda de generalidade quando, neste momento, se admite, para efeito de comparação, a atualização do mesmo. A propósito, esses dois valores são equivalentes segundo o conceito de capitais equivalentes. Ver, a propósito, entre outros, Mathias e Gomes, 1982.

${ }^{78}$ Os indices de remuneração da cademeta de poupança foram fomecidos pela Caixa Econômica Federal; os preços spot, pelo CEPEA-Centro de Estudos Avançados em Economia Aplicada, da ESALQ; os preços futuros pela BM\&F, enquanto as taxas de câmbio e de CDI-over foram extraidas da Revista Juros \& Moedas.
} 
Assumindo-se que o produtor, ao buscar a CPR, está também buscando financiamento, admite-se que o mesmo não possui recursos para financiar o custo de entrada no mercado futuro (comissões mais margem), supondo-se, então, o financiamento de tais recursos ${ }^{79}$, cujos encargos estão expressos pelo componente "T" da equação (21).

Para efeito de verificação de qual estratégia teria sido mais efetiva, se o hedging por CPR ou por futuros, o valor de $x_{p}$ não influencia os resultados. Por isso assumiu-se $x_{p}=1$. Dessa forma, a equação (21) expressa a diferença entre a receita obtida com a venda de uma saca de café no mercado futuro e a venda de uma saca de café através de CPR, no momento da liquidação da posição em futuros, ocasião em ocorre a venda no físico e inversão de posições no mercado futuro.

Se o valor obtido for positivo, o hedging através de futuros terá sido mais vantajoso ${ }^{80}$ para o produtor, na grandeza que o número indicar, ao passo que, se o valor obtido for negativo, a situação se inverte e a vantagem é transferida para a CPR.

A Tabela 16 sintetiza os resultados verificados. Nessa tabela há um conjunto de colunas que exibe valores em cujos cálculos o preço da CPR foi atualizado com $90 \%$ da taxa over, enquanto no outro conjunto, a taxa de atualização foi a de remuneração da caderneta de poupança.

Quando o preço líquido da CPR é transportado no tempo, desde a emissão até seu vencimento, com a aplicação de $90 \%$ da taxa over, percebe-se que para as três regiões consideradas houve dominância do hedging através de CPR em relação aos contratos

\footnotetext{
${ }^{79}$ Os recursos considerados como financiados foram: $R \$ 1.600,00$ de margem por contrato (100 sacas), mais $0,30 \%$ sobre o valor do contrato na entrada e na saída da posição, adicionado de $6,32 \%$, sobre os $0,60 \%$, de taxa operacional (considerou-se a mesma base de cálculo na entrada e na saída, para efeito de simplificação dos cálculos) (BM\&F, bd, 18/08/97). Para apuração dos devidos encargos foi utilizada a taxa CDI-over.

${ }^{80}$ Deve-se lembrar que estâo sendo comparadas duas estratégias de hedging e não uma estratégia de proteção versus uma posição no Ísico comercializada na colheita ao preço de mercado.
} 
futuros. Em 38 observações, o hedging através da Cédula de Produto Rural superou a outra modalidade considerada em 26 oportunidades, perfazendo um percentual de $68,4 \%$.

Tabela 16. hedging CPR $x$ futuros

\begin{tabular}{|c|c|c|c|c|c|c|}
\hline \multirow[b]{2}{*}{ MÊS } & \multicolumn{3}{|c|}{$\mathrm{P}_{\mathrm{cpr}}$ atualizado com $90 \%$ da taxa over } & \multicolumn{3}{|c|}{$P_{\mathrm{cpr}}$ atualizado com a taxa da poupança } \\
\hline & Cerrado & Sul Minas & São Paulo & Cerrado & Sul Minas & São Paulo \\
\hline novembro/95 & - & - & -2.92 & - & - & 3.41 \\
\hline janeiro/96 & 7.07 & - & 6.57 & 11.05 & - & 10.08 \\
\hline fevereiro/96 & -2.73 & - & -151 & 2.83 & - & 3.57 \\
\hline março/96 & 0.2 & -1.96 & 2.99 & 3.72 & 1.47 & 6.07 \\
\hline abril/96 & -3.98 & -4.22 & - & -0.19 & -0.44 & - \\
\hline maio/96 & 2.04 & -0.55 & -5.00 & 4.78 & 2.25 & -2.59 \\
\hline junho/96 & -3.53 & -1.20 & - & -1.11 & 1.02 & - \\
\hline julho/96 & - & -5.02 & - & - & -3.74 & - \\
\hline outubro/96 & - & -5.18 & - & - & 0.05 & - \\
\hline novembro/96 & - & - & -3.14 & - & - & -0.49 \\
\hline dezembro/96 & -5.21 & -6.96 & -8.91 & -3.39 & -4.53 & -7.30 \\
\hline janeiro/97 & -5.69 & -17.85 & -8.82 & -2.88 & -14.34 & -5.98 \\
\hline fevereiro/97 & -0.07 & -0.48 & -2.48 & 4.69 & 4.23 & 1.97 \\
\hline março/97 & 3.32 & 4.29 & -6.90 & 6.47 & 7.16 & -4.13 \\
\hline abril/97 & -1.67 & -3.71 & 1.11 & 1.47 & -0.50 & 3.88 \\
\hline maio/97 & 13.53 & 13.44 & 11.12 & 15.3 & 15.28 & 12.87 \\
\hline junho/97 & 0.11 & -22.14 & - & 1.87 & -19.99 & - \\
\hline
\end{tabular}

Fonte: dados da pesquisa.

No sul de Minas, a predominância dos contratos a termo sobre os futuros atingiu o percentual de 84,6\%, sendo desfavorável apenas nos meses de março e maio de 1997. No cerrado mineiro a vantagem da CPR foi da ordem de $53,8 \%$, ou seja, 7 das 13 observações, distribuídas ao longo dos meses que registraram negócios com o título. Já para São Paulo, a vantagem da CPR sobre os futuros foi de $66,7 \%$, com predominância de resultados positivos em 1997.

Para o segmento que se está considerando (atualização do Popr com $90 \%$ da taxa CDI-over), o valor mais expressivo de dominância da CPR sobre futuros se dá em 
junho/97 para o sul de Minas. Essa supremacia foi de R\$22,14 por saca. Na média das observações, o hedging por CPR superou em R\$ 1,74, por saca, aquele feito com a utilização de futuros.

Quando se aplica a taxa de remuneração da poupança ${ }^{81}$ na atualização do preço da CPR, o resultado se altera. Neste cenário, a predominância dos futuros, que era de 12 observações, no caso anterior, se eleva para 23 , representando $60,5 \%$ do total de registros.

Neste segmento, a região na qual o hedging através de futuros teve sua melhor performance foi a do cerrado mineiro. Dentre 13 possibilidades, a CPR foi superada em 9. No geral, quando se toma a média dos valores registrados na Tabela 16, para a faixa de atualização de preço que se está considerando, a proteção através de futuros superou a obtida por intermédio de CPR em R\$ 1,42 por saca. Aliás, neste caso, todos os indicadores reforçam o melhor desempenho dos futuros.

Por que em janeiro/96 e maio/97 os dados apontam vantagem sistemática (ambas as categorias analisadas) dos futuros sobre a CPR? Quando há essa predominância, temse:

$$
p\left(t^{*}, t^{*}\right)-p\left(t, t^{*}\right)>\left[f\left(t^{*}, T\right)-f(t, T)+I\right]
$$

Assim, quando o termo do lado direito da inequação é positivo (desprezando-se, "I", para efeito de raciocínio), significa que houve elevação do preço relativo ao contrato futuro entre a emissão e o vencimento da CPR. Neste caso, o produtor, com posição vendida em futuros, deveria pagar ajustes diários, tendo prejuízo em sua posição short.

No entanto, nesta situação considerada, o hedging em futuros teria sido melhor do que o efetuado através de CPR. É que, quando ocorre a situação acima, o lado

\footnotetext{
${ }^{81}$ Quando se pensa em custo de oportunidade, a taxa que se aplica é, no mínimo, a taxa de reajuste da cademeta de poupança. Trata-se de um ativo praticamente livre de risco e de fácil acesso a toda a população.
} 
esquerdo da inequação é necessariamente positivo, exigindo-se que a diferença entre o preço spot e o preço da CPR, transportado para o vencimento, supere a diferença entre os preços futuros. Neste caso, como a diferença entre os preços CPR e disponível supera a diferença entre os preços futuros, o hedging através deste último instrumento se caracteriza como uma alternativa melhor, uma vez que se pode liquidá-lo de forma financeira, minimizando a "perda" em relação à proteção obtida via CPR.

A situação do preço disponível elevando-se em relação ao preço da CPR, fazendo com que a diferença entre ambos superasse a diferença entre os futuros, incluindo custo de manutenção da posição, ocorreu para o mês de janeiro/96 e para o Sul de Minas, em maio/97.

Por outro lado, se o termo da direita da desigualdade (22) se mostra negativo, é porque o preço futuro, no vencimento do contrato, foi inferior ao preço praticado quando de sua emissão. Tal fato leva os detentores de posições vendidas a receber ajustes diários, tornando lucrativas tais posições. Isto foi o que ocorreu para o cerrado mineiro e para São Paulo em maio/97.

No entanto, em $(22)$, se $f\left(t^{*}, T\right)-f(t, T)+I<0$, então a diferença entre os preços no disponível e o da CPR pode ser tanto negativa quanto positiva ou nula. Se negativa, uma condição formal deve ser cumprida: medidos em termos absolutos, os valores apurados no lado esquerdo de (22) devem ser menores do que aqueles registrados em seu lado direito.

Se ambos forem negativos, significa que o ganho para o produtor ocorreu tanto na detenção de posições em CPR quanto em futuros, sendo que nessa última modalidade o ganho superou o da primeira.

Já quando o hedging por CPR supera aquele feito por futuros, como ocorreu sistematicamente para as três regiões consideradas nos meses de abril e dezembro de 
1996 e janeiro de 1997 (nas duas modalidades de ajuste do preço da CPR), está-se considerando o caso, onde:

$$
p\left(t^{*}, t^{*}\right)-p\left(t, t^{*}\right)<f\left(t^{*}, T\right)-f(t, T)+I
$$

Matematicamente há duas alternativas a serem consideradas. Se o lado direito for negativo, então o lado esquerdo será necessariamente negativo e superior, em valor absoluto, ao outro termo considerado.

Desprezando-se "I", para efeito de raciocínio, significa que tanto os preços spot quanto os futuros declinaram, quando comparados entre a emissão e o vencimento. Porém, a magnitude de queda do preço disponível, em relação ao preço CPR, foi superior àquela observada para os preços futuros.

Esta situação, levando-se em conta os encargos das posições em futuros, ocorreu, para o $\mathrm{P}_{\text {cpr }}$ corrigido com $90 \%$ da taxa over, para o sul de Minas em junho/97 e para São Paulo em fevereiro e maio de 1996. Quando se utiliza a remuneração da poupança, verifica-se que esse fato ocorreu para o sul de Minas em junho/97 e para São Paulo em maio/96.

A segunda alternativa ocorre quando o lado direito de (23) é positivo. Neste caso, o lado esquerdo tanto pode ser positivo quanto negativo ou nulo. No entanto, como o preço CPR é formado a partir do preço futuro e como, no vencimento, os preços spot e futuro tendem a convergir, então, o cenário mais provável é que, se o lado direito é positivo, o termo da esquerda também o será, aliás, é a situação que ocorreu para os meses e as regiões que foram consideradas.

Mas, o que isto significa? Os termos da direita e da esquerda positivos indicam que tanto o preço futuro quanto o preço disponível em $\mathrm{t}^{*}$ superaram os preços futuro $\mathrm{e}$ $\mathrm{CPR}$, respectivamente, em $t$. No hedging por futuros haveria a necessidade de 
pagamento de ajustes diários, enquanto, em relação ao mercado físico, o hedging por CPR teria se mostrado desfavorável, porém a um nível inferior ao volume financeiro desembolsado no pagamento dos ajustes diários.

Quando um produtor está vendendo CPR, o preço pelo qual o produto vai ser arrematado é um preço bruto, ainda não excluída a taxa de aval. Esse é o referencial para o vendedor. Além disso, como a pesquisa de campo indicou, a maioria não utiliza os mercados futuros ou de opções em suas estratégias de comercialização.

Dessa forma, buscou-se verificar como se comportariam os dados, desprezandose tanto a taxa de aval quanto os custos decorrentes das operações em futuros. $\mathbf{O}$ resultado está consolidado na Tabela 17.

Tabela 17. Hedging CPR $x$ futuros, desconsiderando-se as taxas incidentes

\begin{tabular}{|c|c|c|c|c|c|c|}
\hline \multirow[b]{2}{*}{ MÊS } & \multicolumn{3}{|c|}{$\mathrm{P}_{\text {cpr }}$ atualizado com $90 \%$ da taxa over } & \multicolumn{3}{|c|}{$P_{\mathrm{cpr}}$ atualizado com a taxa da poupança } \\
\hline & Cerrado & Sul Minas & São Paulo & Cerrado & Sul Minas & São Paulo \\
\hline novembro/95 & - & - & -4.47 & - & - & 2.24 \\
\hline janeiro/96 & 6.07 & - & 5.23 & 14.37 & - & 8.90 \\
\hline fevereiro/96 & -4.60 & - & -3.16 & 7.46 & - & 2.11 \\
\hline março/96 & -1.66 & -3.74 & 1.26 & 4.40 & 3.37 & 4.44 \\
\hline abril/96 & -5.62 & -5.93 & - & -5.54 & -0.70 & - \\
\hline maio/96 & 0.54 & -2.03 & -6.47 & .75 & -1.19 & -4.01 \\
\hline junho/96 & -4.58 & -2.19 & - & -7.56 & -5.87 & - \\
\hline julho/96 & - & -5.64 & - & - & -10.11 & - \\
\hline outubro/96 & - & -8.09 & - & - & 0.54 & - \\
\hline novembro/96 & - & - & -5.61 & - & - & -2.83 \\
\hline dezembro/96 & -8.50 & -10.46 & -11.85 & -2.54 & -3.96 & -10.16 \\
\hline janeiro/97 & -9.57 & -21.86 & -12.64 & -4.69 & -11.44 & -9.67 \\
\hline fevereiro/97 & 4.58 & -4.73 & -7.15 & 1.89 & 2.43 & -2.52 \\
\hline março/97 & -1.46 & -0.22 & -11.28 & 4.33 & 4.74 & -8.43 \\
\hline abril/97 & -5.16 & -6.87 & -1.76 & -0.56 & -2.86 & 1.07 \\
\hline maio/97 & 10.21 & 10.62 & 8.31 & 16.74 & 15.35 & 10.09 \\
\hline junho/97 & -3.0 & -25.03 & - & 6.02 & -14.47 & - \\
\hline
\end{tabular}

Fonte: dados da pesquisa. 
O que se observa pela análise da tabela é que para o preço da CPR ajustado com 90\% da taxa CDI-over, a prevalência da CPR sobre futuros, que no caso anterior era de 26 observações dentre 38 , passa para 30 , atingindo o percentual de $78,9 \%$. Já para a outra situação considerada (reajuste pela remuneração da caderneta de poupança), ao invés de 15, verificam-se 19 oportunidades onde ocorrem essa prevalência, saindo-se de um percentual de $39,5 \%$ para $50 \%$.

\subsection{A utilização de opções na apropriação dos diferenciais de elevação de preços}

Como um dos principais temores ostentado pelos produtores em transacionar com CPR é o receio de que o preço se eleve após a venda, procurar-se-á, nesta seção, verificar de forma ex post se esse receio teria sido verdadeiro nas safras de café 96/97 e 97/98. Como se viu na seção 4.2.3, a possibilidade de ganho financeiro utilizando opções de compra, de forma concomitante à CPR, ocorre quando o preço da saca atualizado, obtido com a venda da CPR $\left(\mathrm{P}_{\mathrm{cpr}}\right)$, subtraído do preço spot (S) no vencimento da cédula, é superior ao prêmio que seria pago pela opção de compra.

$\mathrm{Na}$ definição do valor do prêmio, vai-se desconsiderar o valor tempo, por se tratar de uma análise ex post e por considerar-se que a posição é mantida até o seu vencimento, o que a transforma em opção do tipo européia.

$\mathrm{Na}$ busca de dados para a análise, apenas se conseguiu, junto à $\mathrm{BM} \& \mathrm{~F}$, os dados relativos aos prêmios, sem vinculação aos respectivos preços de exercício. Assim, optou-se por uma análise meramente indicativa e limitada, derivada da observação dos prêmios listados diariamente e da observação de alguns preços de exercício, obtidos em boletins diários daquela entidade.

Após a verificação desses dados e com as limitações apontadas, que impediram o ajuste de uma curva, adotou-se para a definição do valor do prêmio uma função linear decrescente, onde para um preço de exercício de $\mathrm{R} \$ 100,00$ o prêmio considerado foi de $\mathbf{R} \$ 20,00$, enquanto para $\mathbf{R} \$ 200,00$ de strike price o prêmio era de $\mathbf{R} \$ 5,00$. Neste caso, 
o preço de exercício considerado não foi o das séries de opções apregoadas na BM\&F, mas sim aquele preço que representa a média mensal dos preços líquidos das $\mathrm{CPR}$, atualizados ou pela poupança ou por $90 \%$ da taxa over.

Tabela 18. Possibilidade de aquisição de opção de compra

\begin{tabular}{|c|c|c|c|c|c|c|}
\hline \multirow{3}{*}{ MÊS } & \multicolumn{6}{|c|}{$P_{\mathrm{cpr}}$ atualizado com $90 \%$ da taxa over } \\
\hline & \multicolumn{2}{|c|}{ Cerrado } & \multicolumn{2}{|c|}{ Sul Minas } & \multicolumn{2}{|c|}{ São Paulo } \\
\hline & $\mathrm{S}-\mathrm{P}_{\text {cor }}$ & Prêmio & $\mathbf{S}-\mathbf{P}_{\text {cor }}$ & Prêmio & $S-P_{c p r}$ & Prêmio \\
\hline nov/95 & - & - & - & - & 8,31 & 17,87 \\
\hline jan/96 & 23,76 & 19,81 & - & - & 21,21 & 19,81 \\
\hline fev/96 & 3,04 & 16,92 & - & - & $-1,96$ & 16,99 \\
\hline $\operatorname{mar} / 96$ & 9,53 & 17,68 & 5,46 & 17,46 & $-1,03$ & 17,70 \\
\hline abr/96 & 5,32 & 17,36 & 4,97 & 17,60 & - & - \\
\hline $\mathrm{mai} / 96$ & 3,95 & 16,97 & 1,32 & 16,60 & $-6,74$ & 15,97 \\
\hline jun/96 & 3,90 & 16,83 & 7,04 & 17,44 & - & - \\
\hline jul/96 & - & - & 6,60 & 18,33 & - & - \\
\hline out/96 & - & - & 98,64 & 18,84 & - & ـ \\
\hline nov/96 & - & - & - & - & 74,51 & 18,51 \\
\hline $\operatorname{dez} / 96$ & 106,66 & 17,77 & 114,89 & 16,72 & 124,80 & 18,43 \\
\hline jan/97 & 89,66 & 14,40 & 74,07 & 14,14 & 86,38 & 14,27 \\
\hline fev/97 & 62,75 & 9,96 & 61,32 & 11,14 & 43,76 & 8,76 \\
\hline $\operatorname{mar} / 97$ & 42,70 & 7,10 & 44,52 & $\mathbf{7 , 8 5}$ & 26,45 & 6,92 \\
\hline $\mathrm{abr} / 97$ & 39,33 & 7,25 & 34,96 & 7,23 & 18,23 & 6,75 \\
\hline mai/97 & 0,15 & 2,80 & 17,15 & 4,21 & 3,40 & 3,49 \\
\hline jun/97 & $-41,44$ & $-3,36$ & $-27,50$ & $-2,73$ & - & - \\
\hline
\end{tabular}

Fonte: dados da pesquisa.

Tabela 19. Possibilidade de aquisição de opção de compra

\begin{tabular}{|c|c|c|c|c|c|c|}
\hline \multirow{3}{*}{ MÊS } & \multicolumn{6}{|c|}{$\mathrm{P}_{\mathrm{cpr}}$ atualizado com a taxa da poupança } \\
\hline & \multicolumn{2}{|c|}{ Cerrado } & \multicolumn{2}{|c|}{ Sul Minas } & \multicolumn{2}{|c|}{ São Paulo } \\
\hline & $S-P_{\text {cor }}$ & Prêmio & $S-P_{c o r}$ & Prêmio & $S-P_{c p r}$ & Prêmio \\
\hline nov/95 & - & - & - & - & 14,65 & 18,82 \\
\hline jan/96 & 27,71 & 20,40 & - & - & 24,72 & 20,33 \\
\hline fev/96 & 8,60 & 17,76 & - & - & 3,12 & 17,75 \\
\hline $\mathrm{mar} / 96$ & 13,06 & 18,21 & 8,89 & 17,98 & 2,06 & 18,87 \\
\hline $\mathrm{abr} / 96$ & 9,10 & 17,93 & 8,75 & 18,16 & - & - \\
\hline mai/96 & 6,30 & 17,45 & 4,12 & 17,02 & $-4,33$ & 16,33 \\
\hline jun/96 & 6,32 & 17,20 & 9,26 & 17,77 & - & - \\
\hline jul/96 & - & - & 7,88 & 18,52 & - & - \\
\hline out/96 & - & - & 103,87 & 19,62 & - & - \\
\hline nov/96 & - & - & - & - & 77,16 & 18,91 \\
\hline $\mathrm{dez} / 96$ & 108,47 & 18,04 & 117,31 & 17,08 & 126,41 & 18,67 \\
\hline jan/97 & 92,47 & 14,82 & $\mathbf{7 7 , 5 7}$ & 14,67 & 89,22 & 14,70 \\
\hline fev/97 & 67,53 & 10,68 & 66,03 & 11,84 & 48,22 & 9,43 \\
\hline $\mathrm{mar} / 97$ & 45,85 & 7,57 & 47,39 & 8,28 & 29,21 & 7,33 \\
\hline abr/97 & 42,46 & 7,72 & 38,16 & 7,71 & 20,99 & 7,16 \\
\hline mai/97 & 1,92 & 3,07 & 18,98 & 4,48 & 5,15 & 3,75 \\
\hline jun/97 & $-39,68$ & $-3,10$ & $-25,35$ & $-2,40$ & - & - \\
\hline
\end{tabular}

Fonte: dados da pesquisa. 
As Tabela 18 e 19 consubstanciam os resultados obtidos. Como já foi dito anteriormente, a possibilidade de aquisição de opções de compra, visando a apropriação dos diferenciais positivos de preços, em caso de elevação, se dá quando a diferença entre os preços spot e CPR supera o prêmio calculado.

Assim, para o cerrado mineiro, no ano de 1996, a utilização de opções de compra só seria factível no mês de janeiro, de forma residual, e, de forma expressiva, em dezembro. Já para o ano de 1997, a utilização de opções de compra seria realizada, com expressivos ganhos, nos meses de janeiro a abril. Em junho, o Pcpr supera o preço disponível, dando ganhos aos produtores que optaram por vender produto através de CPR. Neste último caso, a utilização de opções de compra levaria fatalmente à perda do prêmio pago.

Para o sul de Minas, a estratégia produziria um ganho muito bom em outubro/96 e, de dezembro/96 a maio/97, produziria um ganho excelente em dezembro, para diminuir mês a mês, atingindo um ganho não muito expressivo no último mês dessa série.

A análise para São Paulo produz uma situação similar àquela observada para o sul de Minas trocando-se, apenas, o mês de outubro pelo mês de novembro, na primeira observação e, ainda, registrando-se o ganho residual ocorrido em janeiro de 1996.

Um subproduto que se pode obter pela análise das últimas duas tabelas é a verificação das diferenças entre os preços spot e os preços CPR atualizados. Quando o valor é negativo, o produtor teve, de forma inequívoca, um ganho financeiro direto ao adotar a venda através de CPR, além, obviamente dos ganhos indiretos, como, por exemplo, a garantia de recursos nas épocas próprias e a certeza do escoamento de sua produção. 
$\mathrm{Na}$ Tabela 18, das 38 observações registradas, houve diferença negativa entre os preços CPR e disponível em 5 oportunidades, sendo que 3 delas ocorreram para o estado de São Paulo. Já, com relação à Tabela 19, diferenças negativas ocorreram em apenas 3 registros.

\subsection{Considerações finais sobre o capítulo}

Relembra-se que na seção 6.1 , das 38 observações relativas ao custo de financiamento da CPR, em 14 oportunidades a taxa embutida na transação superou a taxa praticada nas operações de capital de giro. No entanto, na pesquisa de campo (ver Tabela 10), $87 \%$ dos produtores manifestaram-se entre satisfeitos e muito satisfeitos. Além disso, $51,6 \%$ dos produtores declararam seu sentimento de que haviam ganho dinheiro com a utilização da cédula, enquanto $37,1 \%$ entenderam que houve equivalência na alternativa de obtenção de funding através de CPR, quando comparado à alternativa de utilização de recursos próprios ou de crédito rural. Como explicar esse sentimento vis-à-vis os números desfavoráveis ocorridos?

Deve-se notar que para aquelas 14 observações referidas no parágrafo anterior, em 5 o hedging através de CPR superou o efetuado através de futuros, quando utilizada a taxa de $90 \%$ do over para atualização do preço da CPR, contrabalançando as taxas desfavoráveis apuradas.

Recorda-se, ainda, que a CPR cumpre dois papéis diretos: o de levantar fundos para suprir as necessidades da lavoura e o de fixar um preço de venda. De forma indireta, cumpre pelo menos mais dois papéis: a) o de fixar um nível de lucro para a atividade (parcela comercializada), quando permite fixar as receitas e os custos; e b) o de viabilizar os tratos culturais de que a lavoura necessita e, sem os quais haveria queda de produção. Nesta alternativa, afasta do produtor as preocupações acerca da necessidade de avaliar os custos de oportunidade de não praticar os tratos culturais necessários (se 
não dispusesse de dinheiro) e retira-lhe as incertezas, principalmente no que diz respeito ao nível de produção que obteria ${ }^{82}$.

A conjugação desses fatores é que, certamente, fez com que o nível de aceitação da CPR, aferido pela pesquisa de campo e pelos dados quantitativos analisados, se situasse nos padrões registrados.

\footnotetext{
${ }^{82}$ Moreira (1998) ao analisar o prêmio de risco da CPR, chegou à conclusão de que a cédula pode proteger o produtor do risco inerente à indexação a que os financiamentos rurais eram submetidos. Além disso, conclui que a CPR eleva o nivel de utilidade esperada ao proteger o produtor da probabilidade de ocorrência de um evento indesajado (prejuizo financeiro), e é uma altemativa atrativa para a captação de recursos para a agricultura.
} 


\section{CONCLUSÕES}

O cenário vivenciado pelo setor rural, no final da década de 80 e início da década de 90, além da extinção dos subsídios ao campo, foi de extrema escassez de crédito rural. A economia passava por intensa crise fiscal que impunha aos agentes econômicos a busca de soluções situadas fora do aparelho do Estado.

Nesse ambiente de busca de alternativas, surgiram mecanismos que permitiam o financiamento privado das safras, dentre os quais a Cédula de Produto Rural.

A CPR é uma cambial, através da qual o emitente vende a termo sua produção agropecuária, recebendo o valor da venda no ato da formalização do negócio e se comprometendo a entregar o produto vendido na quantidade, qualidade e em local e data estipulados no título. A cédula pode ser emitida para validade entre as partes (vendedor/ comprador) ou pode ser garantida por uma instituição financeira, que honrará a entrega física, caso o vendedor não cumpra as condições contratuais.

No cenário de altas taxas inflacionárias que vigorou por muitos anos no Brasil, a demanda dos produtores rurais sempre foi pela existência de financiamentos em equivalência-produto. A CPR cumpre esse papel. É um financiamento referenciado em produto, que possibilita ao produtor dimensionar seus custos na moeda cujo domínio lhe é estritamente familiar.

Por outro lado, no ato de sua emissão, o preço é travado, gerando vantagens se o preço cair na época que seria natural a comercialização do produto, ou seja, como o 
preço foi fixado ex ante a CPR torna-se, então, um instrumento de hedging contra oscilações para baixo, aumentando a receita do produtor (num cenário de preços desfavoráveis) em comparação com aquela que obteria se não houvesse fixado o preço. No entanto, se o movimento dos preços for ascendente, o produtor não poderá se beneficiar do diferencial de preços vigente (preço de mercado versus preço obtido) pois, na emissão da CPR, já houve a fixação desse valor, de forma consensual entre o vendedor e o comprador. Inclusive, no vencimento da CPR nada mais há a fazer, uma vez que o produtor recebeu o pagamento do produto no fechamento do negócio.

Como se vê, por um lado a CPR desempenha um papel de financiamento e, por outro, um papel de proteção de preços. Além desses dois, desempenhados de forma explícita e direta, cumpre, ainda, de forma indireta, mais dois papéis: a) o de fixar um nível de lucro para a parcela da produção comercializada (receitas e custos fixados); e b) o de viabilizar o plantio/tratos culturais de que a lavoura necessita, afastando das preocupações do produtor o dimensionamento do custo econômico que lhe seria impingido caso esses tratos não fossem realizados.

Um produtor que tenha por objetivo fazer o hedging de sua produção pode fazêlo através de uma, ou da combinação, das seguintes formas: contratos a termo; contratos futuros ou de opções. Nos contratos a termo, além da fixação de preço (caso mais freqüente), deve ocorrer a entrega fisica do produto. Nos mercados futuros, a posição natural de um produtor é a venda de contratos, sem a necessidade de entrega, eis que a liquidação pode ocorrer de forma financeira, pela assunção de uma posição inversa.

No texto há uma discussão a respeito da inserção da CPR no ambiente dos contratos a termo e futuros e também a respeito da substitutibilidade entre esses dois tipos de contratos, concluindo-se, a exemplo de vários autores, não haver substitutibilidade perfeita entre ambos, pois, se um contrato a termo fosse um substituto perfeito para um contrato futuro, não haveria qualquer necessidade de o produtor operar neste último mercado. Ficaria só com os contratos a termo. 
Outra possibilidade de hedging se dá através da compra de opções de venda. Se o objetivo do produtor é assegurar um determinado preço, deverá escolher entre os dois primeiros instrumentos. Se, ao contrário, seu objetivo é o de assegurar um nível mínimo de preços, então deverá tomar posição em opções de venda.

Agora, se a opção do produtor pela CPR decorre de sua necessidade em levantar recursos para o plantio/condução de suas lavouras, o preço fixado pode não lhe ser atraente. $\mathrm{O}$ produtor pode querer tomar posições que lhe garantam a apropriação do diferencial relativo a eventuais elevações de preços. A alternativa seria comprar contratos futuros, arcando com os ajustes diários caso haja queda de preços, ou adquirir opções de compra. Esta última, é uma boa alternativa, se o prêmio estiver em um patamar assimilável pelo produtor. Caso os preços declinem, o produtor perde apenas o prêmio pago. Aliás, em opções, o adquirente do contrato sempre sabe o nível máximo de seu eventual prejuízo, o prêmio.

A CPR por se constituir em um contrato a termo apresenta interações muito fortes com os mercados futuros, além de interagir com os mercados de opções, como forma de complementar estratégias ou de criar posições sintéticas.

Os preços referenciais dos contratos futuros se formam no pit de negociação, a partir da avaliação das condições de oferta e demanda e condensa as expectativas e informações dos players do mercado. Os preços das opções se formam nesse mesmo local e permitem, pela análise dos preços de exercício mais negociados, a inferência das expectativas que estão se formando em relação ao comportamento futuro da commodity. 
Os preços que emergem tanto dos futuros quanto das opções vão balizar as negociações com CPR, cujos preços são formados a partir de leilões eletrônicos ${ }^{83} \mathrm{com}$ alcance nacional. Os preços da CPR vão servir, de certa forma, como um teste para os preços futuros/de opções. Embora investidores alheios ao mercado físico possam participar do mercado, a CPR representa mercadoria a ser entregue pelo produtor e, como tal, seus preços devem guardar estreita relação com a realidade do mercado disponível, propiciando mais uma oportunidade para que os agentes avaliem suas informações e seu nível de expectativas.

Do ponto de vista do hedging, o papel da CPR é bem claro. Ao fixar o preço, protege o produtor contra movimentos de baixa, a exemplo das posições short em futuros e long em opção de venda. Além disso, se a preocupação fundamental do produtor for a de obter financiamento e o mercado indicar possibilidade de elevação dos preços, poderá assumir posição comprada em futuros, a qual lhe propiciará o recebimento de ajustes diários se os preços subirem ou poderá, ainda, adquirir opções de compra, exercendo-a se sua expectativa se confirmar.

Não se deve esquecer, por outro lado, que, do ponto de vista da expansão dos mercados futuros, os compradores de CPR terão uma tendência de travarem suas posições utilizando-se de transações inversas em relação à posição do físico.

Pelo que se viu ao longo deste trabalho, para um produtor rural atuar em mercados futuros haveria um grau razoável de dificuldade pelos custos envolvidos, pela relativa dificuldade de acesso, pela necessidade de financiamento das margens e dos ajustes diários e pela complexidade inerente ao acompanhamento do mercado. Dependendo do porte do produtor e do volume de produção destinado ao hedging, os

\footnotetext{
${ }^{83}$ Por sinal, a CPR transacionada em leilão e com aval de uma instituição financeira rompe com a característica principal dos contratos a termo, a especificidade. Nessas condições, a exemplo dos mercados futuros, também facilita os negócios entre estranhos.
} 
custos (especialmente os de transação) poderiam superar os beneficios dessa alternativa mercadológica.

Restaria, ainda, o mercado de opções. A idéia de "seguro" traduzida por essa modalidade de operação tem apelo para os produtores. Em contraposição aos mercados futuros, com margens e ajustes diários, a alternativa de pagar, unicamente, um prêmio para garantir um preço mínimo é atraente. $O$ que tem dificultado a maior utilização desse instrumento de apoio à comercialização é o valor dos prêmios.

A atuação no mercado a termo ${ }^{84}$, por outro lado, poderia se constituir na melhor alternativa, desde que houvesse a possibilidade de se aferir renda compatível com a realidade global do mercado (em outras palavras, dentro da realidade de preços compatíveis com os mercados spot e futuros, ou com deságios suportáveis, quando há adiantamento monetário). Isso seria verdadeiro porque no mercado a termo normalmente os negócios são feitos com pessoas já conhecidas pelos produtores; porque há o comprometimento físico da mercadoria (realidade mais assimilável pelo produtor) e porque, neste último mercado, a atuação do produtor é do tipo "assume uma posição e esquece".

O que seria interessante, no entanto, seria o produtor olhar para as alternativas disponíveis e construir, a partir da análise de sua realidade e da realidade do mercado, um portfolio que the propiciasse extrair proveito das várias possibilidades existentes. A CPR é um título que não precisa ser utilizado separadamente. Pode muito bem, dadas suas características, ser mesclada a outros instrumentos, complementando as estratégias de comercialização.

Considerando a parte empirica, o trabalho conteve, também, uma pesquisa de campo, baseada na técnica de amostragem aleatória, que buscava aferir o sentimento dos

${ }^{84}$ Conforme exposto em Nelson (1985, p.15), nota de rodapé $n^{\circ} 1$, pesquisa conduzida pelo USDA e pela CFTC apontou uma clara preferência dos produtores por contratos a termo sobre os contratos futuros. 
produtores - que praticaram venda antecipada de café nas safras 96/97 e 97/98 - acerca da CPR e de eventuais transações nos mercados futuros e de opções.

Os principais resultados mostraram: a) que os produtores pouco utilizam os mercados de derivativos agropecuários em suas estratégias de comercialização ${ }^{85}$; b) que a falta de recursos para o custeio da lavoura foi a principal causa de procura pela CPR; c) que continuariam a utilizar o instrumento, mesmo num cenário de abundância de crédito rural; d) o sentimento de que a maioria ganhou dinheiro com a operação; e e) que a quase totalidade dos produtores declarou-se entre satisfeitos e muito satisfeitos com a CPR.

Ainda, com relação à pesquisa de campo, pode-se perceber, ao longo do trabalho, que os produtores que utilizaram CPR em suas estratégias, consideraram que esse instrumento veio preencher uma lacuna existente no mercado, não só quanto ao aspecto "financiamento", mas também no aspecto proteção contra queda de preços ou, alternativamente, como oportunidade de se receber, de forma antecipada, um preço considerado bom. Durante a realização das entrevistas foi muito comum ouvir-se considerações positivas a respeito do título, principalmente considerando ser uma das únicas alternativas de obtenção de recursos à disposição dos produtores de maior porte.

Além disso, percebeu-se, claramente, que a utilização dos mercados futuros como instrumento de fixação de preço cresceu a partir da experiência com a CPR, até porque, muitas das CPR emitidas na safra $98 / 99$ se destinaram a lastrear operações realizadas junto à $B M \& F$.

\footnotetext{
${ }^{85}$ Aliás, para Tomek $(1987$, p.30) as vantagens para o produtor provenientes dos mercados futuros e de opções são de forma indireta, mais do que direta Os beneficios indiretos seriam proporcionados pelos compradores de seu produto e só se tomariam possíveis se houvesse um ativo e rico mercado.
} 
A pesquisa de campo permitiu verificar que vários produtores que haviam travado preço em futuros liquidaram suas posições após sentir que já haviam obtido um lucro razoável com os ajustes diários.

Tais produtores preferiram realizar os lucros à sujeitarem-se à melhoria dos preços que anulariam, no todo ou em parte, o resultado obtido. A propósito, cumpre recordar a observação de Working $(1962$, p.436) sobre o fato de que tem sido conhecido dos hedgers o fato de o hedging usualmente envolver mais do que a prática de se evitar incorrer em riscos (risk avoidance).

Outra questão que o trabalho aborda diz respeito ao papel que a CPR desempenha como instrumento de financiamento. Comparou-se a taxa efetiva do "financiamento" por CPR, com as taxas CDI-over e de capital de giro. Como a taxa over é uma taxa de captação, considera-se que se os recursos tomados tivessem uma taxa de juros próxima a esse referencial, o custo seria interessante. No entanto, de 38 observações, apenas $5(13,2 \%)$ se situaram nesse patamar. Nas demais, $24(63,2 \%)$ se situaram em níveis inferiores à taxa de capital de giro (que seria um teto máximo, por ser uma taxa de curto prazo e vigente para o comércio), enquanto o restante ultrapassou essa taxa.

Além do item acima buscou-se avaliar o papel da CPR enquanto instrumento de hedging, comparando-a com a possibilidade de venda de contratos futuros. Um ajuste teve que ser feito: atualizou-se o preço da CPR, para o seu vencimento, com $90 \%$ da taxa over, numa primeira alternativa, e, em outra, com a taxa de remuneração da caderneta de poupança.

Realizados esses ajustes, percebeu-se que no primeiro caso o hedging por CPR teria sido favorável em $68,4 \%$ das oportunidades, enquanto para o segundo caso, esse percentual atingiu, apenas, 39,5\%. Ou seja, admitindo-se a taxa da poupança na atualização do preço da CPR, a vantagem se transfere para os contratos futuros. 
Por último, considerou-se a possibilidade de o produtor, vendido em CPR, poder se apropriar de eventuais aumentos de preços, pela aquisição de opções de compra. Se considerado o preço da CPR ajustado por $90 \%$ da taxa over, das 38 observações, a possibilidade de renda adicional obtida no mercado de opções ocorreu em 20 oportunidades (52,6\%), sendo que em 4 dessas oportunidades o ganho teria sido apenas residual, enquanto nas outras 16 houve possibilidade de ganhos expressivos. Para o preço da CPR reajustado pela poupança, a situação não se altera, a não ser nos ganhos financeiros que melhoram um pouco.

O estudo, embora trazendo a lume dados anteriormente não disponíveis, apresentou a limitação de se cingir aos dados fornecidos pelo Banco do Brasil. O ideal seria estender a pesquisa, principalmente a de campo, para abranger aqueles produtores que emitem CPR em transação direta com o comprador de seu produto. Essa maior abrangência poderia indicar porque grande parte das operações de CPR estão se dando à margem do sistema financeiro e de registro, e os pontos que estão se constituindo em gargalos para o maior desenvolvimento do instrumento.

Outra questão que mereceria verificação está relacionada à questão cultural. Verificar se esse aspecto produz efetivas limitações ao desenvolvimento de instrumentos como a CPR, futuros e opções e verificar até que ponto um trabalho educativo surtiria efeito, pode ser de grande valia para o desenvolvimento do mercado de mecanismos auxiliares à comercialização da produção.

Referiu-se ao longo do texto na aceitação de taxas de juros elevadas no "financiamento" através de CPR, em contraposição ao custo de oportunidade da não efetivação dos tratos culturais, com reflexos na produção. Dimensionar esses custos e esclarecer os produtores quanto aos deságios e correspondentes encargos financeiros praticados nessas operações poderia ser uma atribuição dos serviços de extensão. Definir-se-ia, a priori, taxas aceitáveis do ponto de vista tanto do produtor como do 
comprador/investidor, de forma que não houvesse tanta discrepância entre as taxas praticadas, conforme se observou com os dados abertos.

Estratégias envolvendo opções constitui-se em um campo ainda a ser perseguido pelos agentes que atuam no mercado. Definir os intervalos de preços para a aquisição das opções vis-à-vis o preço obtido na $\mathrm{CPR}$, e projetado para o futuro, e os prêmios assimiláveis pelos produtores pode se constituir em campo para a atuação de consultores especializados na commodity café e na montagem de operações que permitam a apropriação de ganhos originados de elevações de preços.

Por último, uma questão que mereceria ser aprofundada e que pode ser objeto de outras pesquisas é a questão da CPR com liquidação financeira. Essa modalidade de CPR eliminaria os problemas de classificação e de entrega, objeto de muitas queixas dos produtores; facilitaria a entrada de investidores (não interessados na mercadoria); favoreceria a solidificação de um mercado secundário, mas poderia, também, favorecer a venda de produto não representativo de bens reais. Enfim, as respostas só emergiriam com uma pesquisa sobre o tema. 


\section{REFERÊNCIAS BIBLIOGRÁFICAS}

ACCARINI, J.H. Economia e Desenvolvimento Rural: Reflexões sobre o Caso Brasileiro. Petrópolis, Vozes, 1987, 224 p.

AGRIANUAL 99. Anuário da Agricultura Brasileira. FNP Consultoria \& Comércio; M\&S Mendes e Sestoni e Editora Argos comunicação.

ANFAVEA. Anuário Estatístico (Associação Nacional dos Fabricantes de Veículos Automotores). São Paulo, 1996.

ANUALPEC 98. Anuário da Pecuária Brasileira. FNP Consultoria \& Comércio e Boviplan Consultoria Agropecuária.

ARAÚJO, P.F.C.de; ALMEIDA, A.de. Financiamento da Agricultura: Evolução e Perspectivas. Preços Agrícolas, abril, 1997, p. 3-8.

BACHA, C.J.C. A Cafeicultura Brasileira nas Décadas de 80 e 90 e suas Perspectivas. Preços Agrícolas, v.XII, $n^{\circ} 142,1998$, p. 14-22.

BAHN, H.M. Futures and Options Pilot Program: Some Recent Experiences in the U.S.A. Apresentado no Encontro sobre Futuros e Opções Agrícolas (Op̧̧ões como Instrumento de Política Agrícola) realizado na ESALQ/USP, Piracicaba, 1996.

BARROS, J.R.M.de; MANOEL, A. Insumos Agrícolas: Evolução Recente e Perspectivas. In: BRANDÃO, Antonio S.P. (org.). Os Principais Problemas da Agricultura Brasileira: Análise e Sugestões. Rio de Janeiro, IPEA/INPES, 1988 (Série PNPE, 18).

BANCO DO BRASIL. CPR: Relatório de Atividades, sem data "a”. Brasília-DF.

BANCO DO BRASIL. BB-CPR Cédula de Produto Rural, sem data " $b$ ". Brasília-DF (informação institucional).

BANCO DO BRASIL BB-CPR Cédula de Produto Rural: Diagnóstico, sem data "c". Brasília-DF.

BESSADA, O. O Mercado Futuro e de Opções. Rio de Janeiro, Record, 1995, $2^{\mathrm{a}}$ ed. $299 \mathrm{p}$.

BLACK, F. The Pricing of Commodity Contracts. Journal of Financial Economics. 3, 1976, p.167/79. Reprinted in: WHALEY, R. E. (ed.). Selected Writings on Futures Markets: Interrelations Among Futures, Option, and Futures Option Markets. Chicago, CBOT, 1992, $414 \mathrm{p}$. 
BM\&F-BOLSA DE MERCADORIAS \& FUTUROS. bd (boletim diário, vários números).

BM\&F-BOLSA DE MERCADORIAS \& FUTUROS. Informações Diárias sobre Preços Futuros de Café.

BOTEON, M. Mercado Interno de Frutas Cítricas: Caracterização e Perspectivas para Novos Instrumentos de Comercialização. Piracicaba, 1997, 59 p. Escola Superior de Agricultura Luiz de Queiroz, Universidade de São Paulo (Plano de Dissertação).

BRANCO, A. A Moeda do Campo Sai do Forno. Gazeta Mercantil, 10-12/10/97, p.c-7.

BRASIL. Lei $\mathrm{n}^{\circ} 8.929$, de 22/08/94. Diário Oficial da República Federativa do Brasil, $n^{\circ}$ 161, p. 12.045. Institui a Cédula de Produto Rural, e dá outras providências.

CAMARGO, P.deT. Mercados Futuros: Hedging de Commodities Agrícolas. Rio de Janeiro, 1991 (survey). Não publicado.

CARLTON, D.W. Futures Markets: Their Purpose, Their History; Their Growth, Their Success and Failures. The Journal of Futures Markets, v.1,n.3, p.237-271, 1984.

CASTRO, P.R.de; ALIMANDRO. R.N. Crédito Rural com Mecanismo de Hedge, 1990. Não publicado.

CBOT-CHICAGo BOARD OF TRADE. Manual de Commodities. Promerc-Assoc.p/o Desenvolvimento do Mercados, $390 \mathrm{p}$.

CEPEA-CENTRO DE ESTUDOS AVANÇADOS EM ECONOMIA APLICADA (ESALQ) - Informação Diária sobre Preços de Café (mercado disponível).

CETIP-CENTRAL DE CUSTÓDIA E DE LIQUIDAÇÃO FINANCEIRA DE TÍTULOS - Estoque Semanal de CPRs Registradas.

COCHRAN, W.G. Técnicas de Amostragem. Rio de Janeiro, USAID/Fundo de Cultura, 1965, $555 \mathrm{p}$.

CORRÊA, A.L. Curso de Mercado Futuro e de Opções de Café. São Paulo, BM\&F, $1995,63 \mathrm{p}$.

COSTA NETO, P.L.de O. Estatística. São Paulo, Edgard Blücher, 1977, 264 p. 
COX, J.C.; INGERSOLL, JR., J.E.; ROSS, S.A. The Relation Between Forward Price and Futures Prices. Journal of Financial Economics, vol. 9, 1982, p.321-46. Reprinted in: WHALEY, Robert. E. (ed.). Selected Writings on Futures Markets: Interrelations Among Futures, Option, and Futures Option Markets. Chicago, CBOT, $1992,414 \mathrm{p}$.

DINHEIRO VIVO AGÊNCIA DE INFORMAÇÕES S.A. Juros \& Moedas. Diversos números.

FERGUSON, C.E. Microeconomia. Rio de Janeiro, Forense-Universitária, 1986, 624 p., $9^{\mathrm{a}}$ ed.

FERRARI, A.T. Metodologia da Pesquisa Científica. São Paulo, McGraw-Hill do Brasil, 1982, $318 \mathrm{p}$.

FORBES, L.F. Mercados Futuros: Uma Introdução. São Paulo, Bolsa de Mercadorias \& Futuros (BM\&F), 1994, $68 \mathrm{p}$.

FRANCA, T.J.F. Fontes Alternativas de Financiamento para o Setor Agrícola: O Certificado de Mercadoria com Emissão Garantida - CM-G. Piracicaba, 1997, 125 p. Dissertação de Mestrado (Versão para Defesa). Escola Superior de Agricultura Luiz de Queiroz, Universidade de São Paulo.

FRENCH, K.R. A Comparison of Futures and Forward Prices. Journal of Financial Economics, 12, p. 311-342, 1983.

FRICK, O. Cédula de Produto Rural e o Mercado Futuro Agrícola. Resenha BM\&F, $\mathbf{n}^{\circ}$ 103, p.69-78, jan/fev., 1995.

FRICK, O. Os Indicadores de Preço nos Mercados Futuros. Resenha BM\&F, no 111, julho, 1996.

FRICK, O. Cash \& Carry em Mercados Invertidos. Resenha BM\&F, n 112, p.35-39, ago/set., 1996b.

GASQUES, J.G.; VILLA VERDE, C.M. Crescimento da Agricultura Brasileira e Política Agrícola nos Anos Oitenta. In: XXVIII Congresso Brasileiro de Economia e Sociologia Rural, 1990. Anais. SOBER, 1990, v.1, p.185-213.

GOLDIN, I.; REZENDE, G.C. A Agricultura Brasileira na Década de 80: Crescimento numa Economia em Crise. Rio de Janeiro, IPEA, 1993, 119 p. (Série IPEA, 138). 
GONZALEZ, B.C.de R. A Pequena Empresa e o Setor Informal: uma Análise das Barreiras Existentes ao Livre Crescimento e Transição ao Setor Formal. Porto Alegre, 1989, 182 p. Dissertação de Mestrado. Faculdade de Ciências Econômicas, Universidade Federal do Rio Grande do Sul.

GONZALEZ, B.C.de R. Expectativas para a Agropecuária Brasileira na Década de 90. Banco do Brasil. Comentários Econômicos, III:02-06, 29.01/ 02.02.90.

GONZALEZ, B.C.de R.; COSTA, S.M.A.L. Agricultura: Modernização e Desempenho, Teoria e Evidência Econômica, v.5,n. 10, p.7-35, maio, 1998.

GONZAlez, B.C.de R.; MARQUeS, P.V. A CPR de Café: uma Pesquisa Piloto. Piracicaba, ESALQ, 1998, 20 p. (não publicado).

HULL, J.. Introdução aos Mercados Futuros e de Opções. São Paulo, 1996, BM\&F/Cultura, 448 p. $2^{\mathrm{a}}$ ed.

KAMARA, A. Issues in Futures Markets: a Survey. The Journal of Futures Markets, v.2, no 3, p.261-294, 1982.

JARROW, R.A.; OLDFIELD, G.S. Forward Contracts and Futures Contracts. Journal of Financial Economics, 9, p.373-82, 1981.

JOHNSON, L.L. The Theory of Hedging and Speculation in Commodity Futures. The Review of Economic Studies, 27, p. 139-151, 1960.

LAZZARINI, S.G. Inovação e Organização de Bolsas de Futuros: Uma Discussão Teórica e Evidências no Agribusiness Brasileiro. São Paulo, 1996, 137 p. Faculdade de Economia e Administração, Universidade de São Paulo (projeto de dissertação).

LENCE, S.H.; SAKONG, Y.; HAYES, D.J. Multiperiod Production with Forward and Option Markets. American Journal of Agricultural Economics, 76, p.286-295, 1994 (May).

LEUTHOLD, R.M.; JUNKUS, J.C.; CORDIER, J.E. The Theory and Practice of Futures Markets. Massachussets, Lexington Books, 1989, 410 p.

LIMA, S.M.A.L.; BARROS, G.S.A.de C. Eficácia da Política de Preços Mínimos nos anos 80 e 90: o caso do milho no Brasil. Revista Brasileira de Economia, v.50, $\mathrm{n}^{\circ}$ 2, p.161-78, 1996.

MACHADO, R.R.M. Informações Gerais sobre a CPR, São Paulo, outubro, 1997 (comunicação pessoal). 
MAIA, M.L. Citricultura Paulista: Evolução, Estrutura e Acordos de Preços. Piracicaba, 1992, 185 p. Dissertação de Mestrado. Escola Superior de Agricultura Luiz de Queiroz, Universidade de São Paulo.

MARCONI, M.de A.; LAKATOS, E.M. Técnicas de Pesquisa. São Paulo, Atlas, 1986.

MARQUES, P.V.; MELLO, P.C.de. Mercados Futuros de Commodities Agropecuárias: exemplos e aplicações aos mercados brasileiros. Piracicaba, ESALQ/USP, 1996, 2ª ed., 118 p. (Série Didática, 114).

MARQUES, P.V.; CAFFAGNI, L.C.; SOUZA, E.L.L. Mercados Futuros e Financiamentos Agropecuários. In: VIEIRA, Wilson e CARVALHO, Fátima (Ed.). Mercosul: Agronegócios e Desenvolvimento Econômico. Viçosa, 1997, 296 p.

MARSHALL, J.F. Futures and Option Contracting. Cincinnati, South-Western, 1989, $281 \mathrm{p}$.

MARTINES FILHO, J.G. Pre-Harvest Strategies for Corn and Soybeans: a Comparison of Optimal Hedging Models and Market Advisory Service Recommendations. The Ohio State University, 1996, 287 p. (Ph.D. Thesis).

MATHIAS, W.F.; GOMES, J.M. Matemática Financeira. São Paulo, Atlas, 1982, 486 p.

MOREIRA, A.X. Análise dos Beneficios e do Prêmio de Risco da Cédula de Produto Rural. Viçosa, 1998, 57 p. Dissertação de Mestrado, Universidade Federal de Viçosa.

MUNHOZ, D.G. Economia Aplicada: Técnicas de Pesquisa e Análise Econômica. Brasília, 1989, Edit.Universidade de Brasília, 300 p.

NELSON, R.D. Forward and Futures Contracts as Preharvest Commodity Marketin Instruments. American Journal of Agricultural Economics, v.67, $\mathrm{n}^{\circ} 1$, february, 1985.

NUEVO, P.A.S. A Cédula de Produto Rural (CPR) como Alternativa para Financiamento da Produção Agropecuária. Piracicaba, 1996, 109 p. Dissertação de Mestrado, Escola Superior de Agricultura Luiz de Queiroz, Universidade de São Paulo.

NUEVO P.A.S.; MARQUES, P.V. A Cédula de Produto Rural (CPR) como Alternativa para Financiamento da Produção Agropecuária. In: XXXIV Congresso da SOBER, Aracaju, Anais... v.1,p.617-640, 1996. 
RICHARD, S.F.; SUNDARESAN, M. A Continuous Time Equilibrium Model of Forward Prices and Futures Prices in a Multigood Economy. Journal of Financial Economics, 9, p.347-71, 1981.

RESENHA BM\&F, n 121, BM\&F, São Paulo, dezembro/97-janeiro/98.

REZENDE, G.C.de Inflação, Preços Mínimos e Comercialização Agrícola: a Experiência dos Anos 80. In: BRANDÃO, Antonio S.P. (org.). Os Principais Problemas da Agricultura Brasileira: Análise e Sugestões. Rio de Janeiro, IPEA/INPES, 1988 (Série PNPE, 18).

REZENDE, G.C.de Do Cruzado ao Collor: os Planos de Estabilização e a Agricultura. Revista de Economia Política, v.12, nº 2(46), p.106-125, abr/jun, 1992.

ROCHELLE, T.C.P. O Contrato Futuro de Boi Gordo: Uma Análise do Impacto da Introdução da Liquidação Financeira sobre o Risco de Base. Piracicaba, 1997, 138 p. Escola Superior de Agricultura Luiz de Queiroz, Universidade de São Paulo (dissertação de mestrado, versão apresentada para defesa).

RUIZ, J.A. Metodologia Científica: Guia para Eficiência nos Estudos. São Paulo, Atlas, $1989,2^{\mathrm{a}}$ ed., $183 \mathrm{p}$.

SAYAD, J. Crédito Rural no Brasil: Avaliação das Críticas e das Propostas de Reforma. São Paulo, Fipe/Pioneira, 1984, 125 p.

SILVA, L.M. da Mercado de Opções: Conceitos e Estratégias. Rio de Janeiro, Halip, 1996, $276 \mathrm{p}$.

SOARES, P. Crescem as Operações com CPR. Gazeta Mercantil, 26.06.97, p. c-9.

SOBOLL W. Novos Instrumentos de Negociação no Mercado Físico. Piracicaba, Esalq, 1996. In: $7^{\circ}$ Curso de Comercialização de Commodities Agropecuárias, p. 6.1/6.34.

SOM, RK. Practical Sampling Techniques. New York, Marcel Dekker, 1996, 634 p.

SOUZA, W.A. de. O Mercado Futuro como Instrumento de Comercialização para o Empresário Rural. Lavras, 1994, 90 p. Dissertação de Mestrado, Escola Superior de Agricultura de Lavras.

TELSER, L.G. Why There Are Organized Futures Markets. The Journal of Law and Economics, v.64, no 1, p.1-22, april, 1981.

TELSER, L.G.; HIGINBOTHAM, H.N. Organized Futures Markets: Costs and Benefits. Journal of Political Economy, v.85, $\mathrm{n}^{\circ}$ 5, p. 969-1000, october, 1977. 
TOMEK, W.G. Effects of Futures and Options Trading on Farm Incomes. In: Symposium Proceedings of Options, Futures, and Agricultural Commodity Programs. Commodity Economic Division, Economic Research Service, USDA Staff Reports AGES \# 870911, 1987, p.21-33.

WALMSLEY, J. The New Financial Instruments: An Investor's Guide. New York, John Wiley \& Sons, 1988, 454 p.

WILLIAMSON, O.E. The Economic Institutions of Capitalism. New York, The Free Press, 1985.

WILlIAMS, J. The Economic Function of Futures Markets. New York, Cambridge University Press, 1986.

WORKING, H. Futures Trading and Hedging. The American Economic Review, v.43, $\mathrm{n}^{\circ}$ 3, p.314-343, 1953.

WORKING, H. Hedging Reconsidered. Journal of Farm Economics, v.35, $\mathrm{n}^{\circ} 4$, p.544-561, 1953.

WORKING, H. New Concepts Concerning Futures Markets and Prices. The American Economic Review, v.52, p.431-459, 1962.

WORKING, H. Economic Functions of Futures Markets. In: Futures Trading in Livestock - Origins and Concepts, edited by H.Bakken, 1970, CME.

ZYLBERSZTAJN, D.; NEVES, M.F. Illicaffè: Coordenação em Busca da Qualidade. PENSA, São Paulo, 1993 (Estudo de Caso EC.004.93). 


\section{PESQUISA. O AMBIENTE NEGOCAL DA GPR}

I. AGÊNCIA:

II. NOME DO PRODUTOR:

III. N' DAS CPRs CONTRATADAS (nº da operação no Banco):

1. ÁREA DE CULTIVO (informar em hectares):

ha

2. NÚMERO DE PÉS PLANTADOS:

3. SE JÁ EFETUOU VENDAS ANTECIPADAS, ASSINALAR A MODALIDADE E A RESPECTIVA CULTURA:
a) CPR:
$\square$ café
$\square$ outra. Qual?
b) OUTRA MODALIDADE: $\square$ café
$\square$ outra. Qual?

4. EM COMPLEMENTO À OPERAÇÃO DE CPR, OPEROU EM:
a) contratos futuros?
$\square \operatorname{sim}$
$\square$ não
b) opções?
$\square \operatorname{sim}$
$\square$ não

5. EXCETUANDO OS NEGÓCIOS DO ITEM ANTERIOR, ALGUMA VEZ JÁ OPEROU EM:
a) contratos futuros?
$\square \operatorname{sim}$
$\square$ não
b) opções?
$\square \operatorname{sim}$
$\square$ não

6. TENDO OPERADO EM MERCADOS FUTUROS OU DE OPÇÕES, QUAL FOI $O$ RESULTADO?

$\square$ satisfatório $\quad \square$ nulo $\quad \square$ insatisfatório

7. EM QUANTAS SAFRAS VENDEU CAFÉ ATRAVÉS DE CPR?
1 safra;
2 safras;
3 safras
4 safras

8. CITAR O PRINCIPAL MOTIVO PELO QUAL OPTOU PELA CPR:

$\square$ falta de recursos para financiamento do custeio.

$\square$ antecipação da comercialização, garantindo preço.

outro. Citar 


\section{PESQUISA. 0 AMBIENTE NEROCAL DA GPR}

9. QUAL O NÍVEL DE SATISFAÇÃO COM A UTILIZAÇÃO DA CPR?

$\square$ muito satisfeito satisfeito nada acrescentou

$\square$ insatisfeito

10. SE A RESPOSTA AO ITEM ANTERIOR FOI "INSATISFEITO", CITAR A RAZÃO:

$\square$ os preços elevaram-se após a venda.

$\square$ o produto não foi aceito pelo comprador.

$\square$ preço recebido muito baixo em relação ao praticado no mercado (deságio alto).

$\square$ houve grande demora por parte do banco.

$\square$ outra. Citar.

11. COMPARANDO COM O CUSTEIO ATRAVÉS DE RECURSOS PRÓPRIOS OU DE CRÉDITO RURAL, QUE NÃO EXIGEM A FZXAÇÃO DE PREÇOS, VOCÊ ACHA

$\square$ que ganhou dinheiro

$\square$ que empatou

$\square$ que perdeu dinheiro

12. COMO VOCÊ TEM EMITIDO CPR?

$\square$ com o aval de banco.

com o aval de instituição/empresa não bancária.

$\square$ em negócio direto com sua cooperativa.

$\square$ em negócio direto com compradores tradicionais.

13. SE EMITIU CPR SEM AVAL, QUAL FOI A RAZÃO?

$\square$ custo do aval.

$\square$ dificuldade no oferecimento de garantias.

$\square$ o comprador da CPR não exigiu.

outra. Citar.

14. SE HOUVER RECURSOS DE CRÉDITO RURAL E SE NÃO HOUVER LIIMITAÇÕES EM SUA UTILIZAÇÃO

$\square$ continuaria a utilizar CPR?

$\square$ desistiria de sua utilização? 
15. EM SUA OPINIÃO, O QUE FALTA PARA QUE A CPR SE CONSTITUA EM UM TÍTULO QUE POSSA MELHOR AJUDAR O PRODUTOR RURAL?

a)

b)

c)

16. VENDIDA A PRODUÇÃO A PREÇO FLXADO, VOCÊ TEM CONHECIMENTO DE QUE PODE SE BENEFICIAR DE EVENTUAIS AUMENTOS DE PREÇOS ATRAVÉS DOS MERCADOS FUTUROS E DE OPÇÕES?

$\square \operatorname{sim} \quad \square$ não 
CETIP - ESTOQUE SEMANAL DE CPR - 29/02/96 a 29/12/97

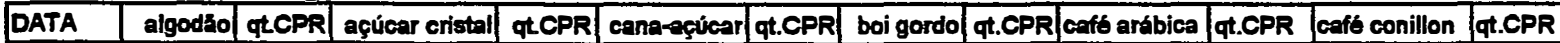

\begin{tabular}{|c|c|c|c|c|c|c|c|c|c|c|c|c|}
\hline $29 / 0286$ & 2236800 & 75 & 7960000 & 331 & 6268660 & 105 & 109638 & 16 & 40483 & 69 & & \\
\hline $05 / 0396$ & 2236800 & 75 & 7960000 & 331 & 6268680 & 105 & 112438 & 17 & 44433 & 72 & & \\
\hline $1203 / 96$ & 2236800 & 75 & 7960000 & 331 & 6268660 & 105 & 105638 & 15 & 45433 & 75 & & \\
\hline 21/03/96 & 2236800 & 75 & 7960000 & 331 & 6268660 & 105 & 76932 & 13 & 46433 & 77) & & \\
\hline $26 / 03 / 96$ & 2236800 & 75 & 7960000 & 331 & 6268660 & 105 & 89507 & 15 & 48433 & 81 & & \\
\hline $23104 / 96$ & 2236800 & 75 & 7960000 & 331 & 6303915 & 107 & 124992 & 24 & 60133 & 110 & & \\
\hline $30 / 04 / 96$ & 2236800 & 75 & 7960000 & 331 & 7135415 & 111 & 126692 & 24 & 62933 & 115 & & \\
\hline $07 / 05 / 96$ & 2236800 & 75 & 7960000 & 331 & 7247728 & 113 & 126692 & 24 & 63833 & 119 & & \\
\hline $14 / 05 / 96$ & 2236800 & 75 & 7960000 & 331 & 7419757 & 115 & 136872 & 24 & 66033 & 123 & & \\
\hline $21 / 05 / 86$ & 2236800 & 75 & 7960000 & 331 & 7419757 & 115 & 166567 & 29 & 69633 & 132 & & \\
\hline $3005 / 96$ & 2236800 & 75 & 7960000 & 331 & 7419757 & 115 & 165127 & 28 & 72083 & 138 & & \\
\hline $04 / 06 / 96$ & 2236800 & 75 & 7960000 & 331 & 7361957 & 115 & 179879 & 30 & 72083 & 138 & & \\
\hline $11 / 06 / 96$ & 2236800 & 75 & 7960000 & 331 & 7563957 & 118 & 182894 & 32 & 72083 & 138 & & \\
\hline $25 / 06 / 96$ & 2236800 & 75 & 7960000 & 331 & 7563957 & 118 & 184016 & 31 & 74463 & 144 & & \\
\hline $09107 / 96$ & 2236800 & 75 & 7960000 & 331 & 8155157 & 119 & 169216 & 29 & 73763 & 143 & & \\
\hline $16 / 07 / 96$ & 2236800 & 75 & 7860000 & 331 & 8155157 & 119 & 169216 & 29 & 66463 & 134 & & \\
\hline $23 / 07 / 96$ & 2236800 & 75 & 7960000 & 331 & 8385137 & 123 & 183761 & 30 & 66463 & 134 & & \\
\hline $30 / 07 / 96$ & 2236800 & 75 & 7960000 & 331 & 14764315 & 125 & 183761 & 30 & 66463 & 134 & & \\
\hline $06 / 08 / 96$ & 2236800 & 75 & 7960000 & 331 & 8530912 & 122 & 183761 & 30 & 66463 & 134 & & \\
\hline 150896 & 2236800 & 75 & 7960000 & 331 & 8526120 & 122 & 183054 & 31 & 65463 & 133 & & \\
\hline $20 / 08 / 96$ & 2236800 & 75 & 7960000 & 331 & 8044829 & 46 & 183054 & 31 & 65463 & 133 & & \\
\hline $27 / 03 / 96$ & 1593333 & 74 & 7960000 & 331 & 8548564 & 49 & 175492 & 35 & 65463 & 133 & & \\
\hline $03 / 09 / 96$ & 1593333 & 74 & 7960000 & 331 & 8177919 & 45 & 173492 & 35 & 7850 & 10 & & \\
\hline $09 / 09 / 86$ & 1593333 & 74 & 7960000 & 331 & 8175919 & 45 & 160881 & 34 & 4950 & 4 & & \\
\hline $17 / 09 / 96$ & 1593333 & 74 & 7960000 & 331 & 6571706 & 57. & 160881 & 34 & 4950 & 4 & & \\
\hline $24 / 09 / 96$ & 1593333 & 74 & 7960000 & 331 & 6571706 & 57 & 152081 & 31 & 4950 & 4 & & \\
\hline $01 / 10 / 96$ & 1593333 & 74 & 7960000 & 331 & 6509206 & 56) & 166722 & 34 & 4650 & 3 & & \\
\hline $08 / 10 / 96$ & 1593333 & 74 & 7960000 & 331 & 6693506 & 65 & 158772 & 31 & 4650 & 3) & & \\
\hline $21 / 10 / 96$ & 1593333 & 74 & 7960000 & 331 & 6751156 & 67 & 147817 & 30 & 3450 & 2 & & \\
\hline $28 / 10 / 96$ & 1593333 & 74 & 7960000 & 331 & 5434656 & 66 & 150463 & 31 & 3450 & 2 & & \\
\hline $04 / 11 / 96$ & 1593333 & 74 & 7960000 & 331 & 7202569 & 65 & 152120 & 33 & 3450 & 2 & & \\
\hline $11 / 11 / 96$ & 1593333 & 74 & 7960000 & 331 & 7003566 & 64 & 111413 & 27 & 5570 & 4 & & \\
\hline 18/11/96 & 1593333 & 74 & 7960000 & 331 & 7003566 & 64) & 99861 & 26 & 2724 & 4 & & \\
\hline $25 / 11 / 96$ & 1593333 & 74 & 7960000 & 331 & 7003566 & 64 & 115496 & 31 & 3224 & 5 & & \\
\hline 02/12/96 & 1593333 & 74 & 7960000 & 331 & 7432948 & 74) & 114111 & 31 & 3977 & 7 & & \\
\hline 09/12/96 & 1593333 & 74 & 7960000 & 331 & 7432948 & 74) & 141291 & 33. & 7177 & 9 & & \\
\hline $16 / 12 / 96$ & 1593333 & 74 & 7960000 & 331 & 5752346 & 69. & 142891 & 34 & 9277 & 11 & & \\
\hline $23 / 12 / 96$ & 1593333 & 74 & 7960000 & 331 & 5794119 & 70 & 142791 & 34 & 10377 & 12 & & \\
\hline 27/12/96 & 1593333 & 74 & 7960000 & 331 & 5794119 & 70 & 145191 & 36 & 10577 & 14 & & \\
\hline 06/01/97 & 1593333 & 74. & 7960000 & 331 | & 5794119 & 70 & 145191 & 36 & 10577| & 14 & & \\
\hline 13/01/97 & 1593333 & 74 & 7960000 & 331 & 5794119 & 70 & 202646 & 36 & 10877 & 16 & & \\
\hline $20 / 01 / 97$ & 1593333 & 74. & 7980000 & 331 & 5892221 & 71 & 202646 & 36 & 12677 & 20 & & \\
\hline $27 / 01 / 97$ & 1593333 & 74 & 7960000 & 331 & 5918871 & 72 & 182971 & 36 & 15077 & 25 & & \\
\hline 03.0297 & 1593333 & 74 & 7960000 & 331 & 5918871 & 72 & 134891 & 37 & 20777 & 36 & & \\
\hline $07 / 02 / 97$ & 1596667 & 75 & 7960000 & 331 & 5918871 & 72 & 216426 & 40 & 22577 & 41 & & \\
\hline $17 / 02 / 97$ & 1596667 & 75 & 7960000 & 331 & 5918871 & 72 & 213926 & 39 & 22577 & 41 & & \\
\hline $24 / 0297$ & 1596667 & 75 & 7960000 & 331 & 5918871 & 72 & 210926 & 38 & 29157 & 55 & & \\
\hline $03 / 03 / 97$ & 1596667 & 75 & 7960000 & 331 & 5918871 & 72 & 197391 & 34) & 29157 & 55 & & \\
\hline $10 / 03 / 97$ & 1596667 & 75 & 7960000 & 331 & 5918871 & 72 & 198105 & 34 & 30705 & 56 & & \\
\hline $17 / 03 / 97$ & 1596667 & 75 & 7960000 & 331 & 5918871 & 72 & 207309 & 37 & 46935 & 90 & & \\
\hline $24 / 03 / 97$ & 1596667 & 75 & 7960000 & 331 & 7382871 & 74 & 199134 & 34) & 54855 & 119 & 300 & 1 \\
\hline $31 / 03 / 97$ & 1596667| & 75 & 7960000 & 331 & 7605871 & 75 & 196354 & 33. & 60225 & 133 & 800 & \\
\hline
\end{tabular}


CETIP - ESTOQUE SEMANAL DE CPR - 29/02/96 a 29/12/97

(contimação)

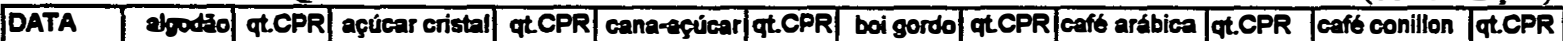

\begin{tabular}{|c|c|c|c|c|c|c|c|c|c|c|c|c|}
\hline $07 / 04 / 97$ & 1596667 & 75 & 7960000 & 331 & 7605871 & 75 & 202294 & 35 & 103855 & 154 & 800 & 2 \\
\hline $14 / 04 / 97$ & 1596667 & 75 & 7960000 & 331 & 7605871 & 75 & 213094 & 38 & 110555 & 178 & 800 & 2 \\
\hline $1804 / 97$ & 1596667 & 75 & 7960000 & 331 & 7605871 & 75 & 212234 & 38 & 116955 & 202 & 800 & 2 \\
\hline $2804 / 97$ & 1596667 & 75 & 7960000 & 331 & 7605871 & 75 & 214880 & 39 & 128355 & 236 & 800 & 2 \\
\hline $05 / 05 / 97$ & 1596667 & 75 & 7960000 & 331 & 7780270 & 76 & 184150 & 35 & 139055 & 277 & 800 & 2 \\
\hline $1205 / 97$ & 1596667 & 75) & 7960000 & 331 & 7780270 & 76 & 170495 & 31 & 155055 & 318 & 800 & 2 \\
\hline $19 / 05 / 97$ & 1596687 & 75 & 7960000 & 331 & 8123938 & 77 & 170495 & 31 & 167655 & 366 & 1800 & 4 \\
\hline $26 / 05 / 97$ & 1596667 & 75 & 7960000 & 331 & 8123938 & 77 & 163635 & 28 & 183655 & 408 & 1800 & 4 \\
\hline 020697 & 1596667 & 75 & 7960000 & 331 & 8107738 & 76 & 161775 & 27 & 197235 & 437 & 1800 & 4 \\
\hline $09 / 06 / 97$ & 1596667 & 75 & 7960000 & 331 & 8107738 & 76 & 162965 & 27 & 218235 & 464 & 1800 & 4 \\
\hline $16 / 06 / 97$ & 1596667 & 75 & 7960000 & 331 & 8171738 & 78 & 162125 & 26 & 222335 & 480 & 1800 & 4 \\
\hline $23 / 06 / 97$ & 1596667 & $75 \mid$ & 7960000 & 331 & 8171738 & 78 & 162125 & 26 & 225435 & 488 & 1800 & 4 \\
\hline 300697 & 1593339 & 74) & 7960000 & 331 & 6598326 & 62 & 165125 & 27 & 230835 & 507 & 1800 & 4 \\
\hline 07107/97 & 1593333 & 74 & 7960000 & 331 & 6598326 & 62 & 155750 & 26 & 230031 & 505 & 1200 & 3 \\
\hline 14/07/97 & 1593333 & 74 & 7960000 & 331 & 6435734 & 47 & 157550 & 27 & 215931 & 463 & 1200 & 3 \\
\hline $21 / 07 / 97$ & 1593333 & 74 & 7980000 & 331 & 6435734 & 47 & 152505 & 25 & 209831 & 455 & 1200 & 3 \\
\hline $28 / 07 / 97$ & & & & & 6973525 & 61 & 127635 & 23 & 208831 & 449 & & \\
\hline $04 / 08 / 97$ & & & & & 6941890 & 60 & 133115 & 23 & 201731 & 432 & & \\
\hline $18 / 08 / 97$ & & & & & 6941890 & 60 & 135115 & 24 & 189378 & 406 & & \\
\hline $25 / 08 / 97$ & & & & & 6941890 & 60 & 135115 & 24 & 144078 & 384 & & \\
\hline $01 / 09 / 97$ & & & & & 6189195 & 39 & 123411 & 22 & 181450 & 335 & & \\
\hline $08 / 09 / 97$ & & & & & 6189195 & 39 & 123411 & 22 & 74368 & 177 & & \\
\hline $15 / 09 / 07$ & & & & & 6189195 & 39 & 129479 & 23 & 38088 & 73 & & \\
\hline $22 / 09 / 97$ & & & & & 6189195 & 39 & 125154 & 22 & 36228 & 67 & & \\
\hline 29/09/97 & & & & & 6189195 & 39 & 128904 & 22 & 34428 & 62 & & \\
\hline $06 / 10 / 97$ & & & & & 6189195 & 39 & 149012 & 24 & 17648 & 58 & & \\
\hline 13/10/97 & & & & & 6189195 & 39 & 144580 & 22 & 14648 & 55 & & \\
\hline $20 / 10 / 97$ & & & & & 6281347 & 53 & 144580 & 22 & 14648 & 55 & & \\
\hline $27 / 10 / 97$ & & & & & 6281347 & 53 & 144580 & 22 & 13100 & 54 & & \\
\hline $03 / 11 / 97$ & & & & & 5414717 & 51 & 74560 & $\overline{22}$ & 13100 & 54 & & \\
\hline 10/11/97 & & & & & 5414717 & 51 & 76660 & 22 & 4800 & 12 & & \\
\hline $17 / 11 / 97$ & 2647 & 1 & & & 5414717 & 51 & 87910 & 22 & 9300 & 12 & & \\
\hline $24 / 11 / 97$ & 2647 & 1 & & & 5414717 & 51 & 96340 & 24 & 9300 & 12 & & \\
\hline $01 / 12 / 97$ & 2647 & 1 & & & 4884938 & 39 & 96340 & 24 & 12200 & 17 & & \\
\hline $08 / 12 / 97$ & 2647 & 1 & & & 4999167 & 42 & 94340 & 23 & 18900 & 31 & & \\
\hline 15/12/97 & 2647 & 1 & & & 5061386 & 44 & 93661 & 22 & 21800 & 36 & & \\
\hline $22 / 12 / 97$ & 2647 & 1 & & & 5061386 & 44 & 88261 & 21 & 26300 & 42 & & \\
\hline $29 / 12 / 97$ & 2647 & 1 & & & 5061386 & 44 & 91301 & 22 & 30800 & 53 & & \\
\hline
\end{tabular}

unidades de peso: algodão e boi gordo: arroba; açúcar cristal e cafe: $k g$; cana-de-açúcar: tonelada 
CETIP - ESTOQUE SEMANAL DE CPR - 29/02/96 a 29/12/97

(contimuacāo)

DATA trigo qt.CPR mitho qt.CPR soje qt.CPA tomate qt.CPR batrosem. qt.CPR loito in nature qt.CPR

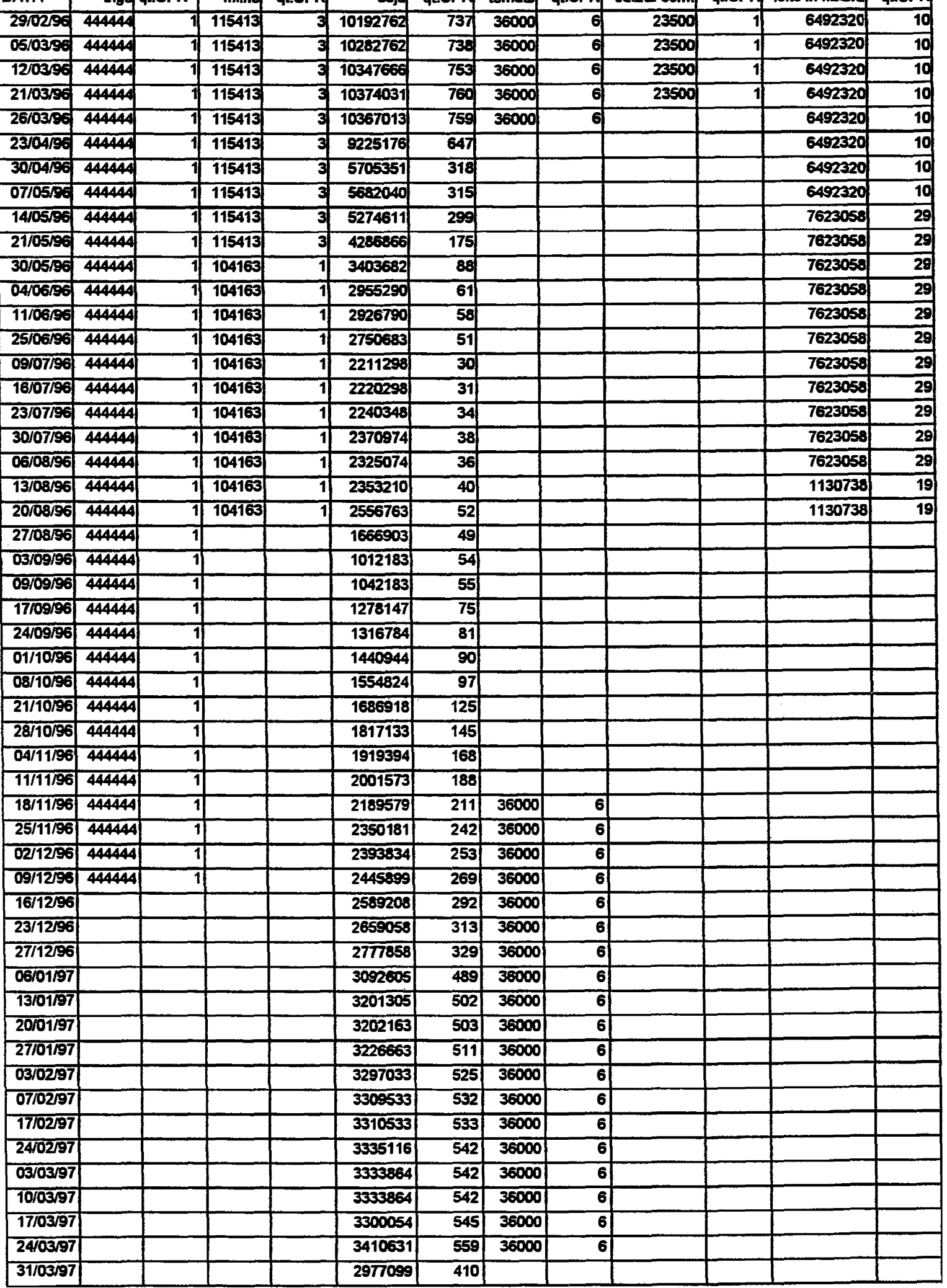


CETIP - ESTOQUE SEMANAL DE CPR - 29/02/96 a 29/12/97 (continuação)

\begin{tabular}{|c|c|c|c|c|c|c|c|c|c|c|c|}
\hline DATA & trigo qt.CPR & milho & qLCPR & soja & qt.CPR & tomate & qt.CPR & betrosem. & qt.CPR & loite in natura & qt.CPR \\
\hline 07/04/97 & & & & 2979799 & 412 & & & & & & \\
\hline $14 / 04 / 97$ & & & & 2921799 & 409 & & & & & & \\
\hline $18 / 04 / 97$ & & & & 2849131 & 401 & & & & & & \\
\hline $28 / 04 / 97$ & & & & 2834604 & 394 & & & & & & \\
\hline 05/05/97 & & & & 1580650 & 228 & & & & & & \\
\hline $12 / 05 / 97$ & & & & 1558500 & 220 & & & & & & \\
\hline 19/05/97 & & & & 1286077 & 150 & & & & & & \\
\hline 26/05/97 & & & & 1086153 & 108 & & & & & & \\
\hline $02 / 06 / 97$ & & & & 507681 & 21 & & & & & & \\
\hline $09 / 06 / 97$ & & & & 507681 & 21 & & & & & & \\
\hline $16 / 06 / 97$ & & & & 504281 & 19 & & & & & & \\
\hline $23 / 06 / 97$ & & & & 498431 & 17 & & & & & & \\
\hline $30 / 06 / 97$ & & & & 490178 & 14 & & & & & & \\
\hline 07/07/97 & & & & 553178 & 15 & & & & & & \\
\hline $14 / 07 / 97$ & & & & 403420 & 9 & & & & & & \\
\hline $21 / 07 / 97$ & & & & 403420 & $\overline{9}$ & & & & & & \\
\hline $28 / 07 / 97$ & & & & 158420 & 7 & & & & & & \\
\hline $04 / 08 / 97$ & & & & 168341 & 8 & & & & & & \\
\hline 18/08/97 & & & & 209463 & 13 & & & & & & \\
\hline $25 / 08 / 97$ & & & & 233963 & 16 & & & & & & \\
\hline 01/09/97 & & & & 269963 & 18) & & & & & & \\
\hline 08/09/97 & & & & 318563 & 20 & & & & & & \\
\hline $15 / 09 / 07$ & & & & 318563 & 20 & & & & & & \\
\hline $22 / 09 / 97$ & & & & 391834 & 26 & & & & & & \\
\hline 29/09/97 & & & & 396834 & 27) & & & & & & \\
\hline $06 / 10 / 97$ & & & & 463901 & 42 & & & & & & \\
\hline 13/10/97 & & & & 533901 & 44 & & & & & & \\
\hline 20/10/97 & & & & 533901 & 44 & & & & & & \\
\hline 27/10/97 & & & & 533901 & 44 & & & & & & \\
\hline 03/11/97 & & & & 130894 & 61 & & & & & & \\
\hline 10/11/97 & & & & 654877 & 69 & & & & & & \\
\hline 17/11/97 & & & & 671127 & 72 & & & & & & \\
\hline 24/11/97 & & & & 702237 & 79 & & & & & & \\
\hline $01 / 12 / 97$ & & & & 655737 & 84 & & & & & & \\
\hline $08 / 12 / 97$ & & & & 721837 & 90 & & & & & & \\
\hline 15/12/97 & & & & 777237 & 108 & & & & & & \\
\hline $22 / 12 / 97$ & & & & 841747 & 120 & & & & & & \\
\hline 29/12/97 & & & & 895712 & 135 & & & & & & \\
\hline
\end{tabular}

unidades de peso: trigo, milho, soja e batata semente: $\mathrm{kg}$; tomate: tonelada; leite: litro. 